


\section{Shakespeare, Caravaggio, and the Indistinct Regard}

This volume presents a contrastive study of the overlapping careers of Shakespeare and Caravaggio through the comparison of their strikingly similar conventional belief in symbol and the centrality of the subject, only to gradually open it up in an exaltation of multiplicity and the "indistinct regard" (Othello).

Utilizing a methodological premise on the notions of early modern indistinction and multiplicity, Shakespeare, Caravaggio, and the Indistinct Regard analyses the survival of English art after iconoclasm and the circulation of Italian art and motifs, methodologically reassessing the conventional comparison between painting and literature. The book examines Caravaggio's and Shakespeare's works in the perspective of the gradual waning of symbolism, the emergence of chiaroscuro and mirror imagery underneath their radically new concepts of representation, and the triumph of multiplicity and indistinction. Furthermore, this work assesses the validity of the twin concepts of multiplicity and indistinction as an interpretive tool in a dialectical interplay with much recent work on indeterminacy in literary criticism.

Rocco Coronato is an Associate Professor of English Literature at the University of Padova, Italy. A visiting academic at Amsterdam, Harvard, Warburg Institute, Brown University, Chicago, he has written articles and chapters for international journals and collection of essays. His monographs include: Shakespeare's Neighbors: Theory Matters in the Bard and His Contemporaries (University Press of America, 2001); Jonson Versus Bakbtin: Carnival and the Grotesque (Rodopi, 2003); La mano invisibile: Shakespeare e la conoscenza nascosta (Pacini, 2011); La linea del serpente: caos e creazione in Milton, Sterne e Coleridge (Pacini, 2012); Intorno a Shakespeare: re e confessori, marinai e vedove, delinquenti e attori (Aracne, 2013). His research interests include the influence of classical and early modern European sources on English writers from the 16 th to the 18 th century, the application of complexity theory to literary interpretation and the digital humanities. 


\section{Anglo-Italian Renaissance Studies \\ Edited by Michele Marrapodi}

For a full list of titles in this series, please visit www.routledge.com.

11 Translating Women in Early Modern England

Gender in the Elizabethan Versions of Boiardo, Ariosto and Tasso

Selene Scarsi

12 Shakespeare and Renaissance Literary Theories

Anglo-Italian Transactions

Edited by Michele Marrapodi

13 Shakespeare, Politics, and Italy

Intertextuality on the Jacobean Stage

Michael J. Redmond

14 Italian Culture in the Drama of Shakespeare and His Contemporaries

Rewriting, Remaking, Refashioning

Edited by Michele Marrapodi

15 Shakespeare and Rome

Graham Holderness

16 Shakespeare's Poetics

Aristotle and Anglo-Italian Renaissance Genres

Sarah Dewar-Watson

17 Theatre, Magic and Philosophy

William Shakespeare, John Dee, and the Italian Legacy

Gabriela Dragnea Horvath

18 Shakespeare's Poetics

Aristotle and Anglo-Italian Renaissance Genres

Sarah Dewar-Watson

19 Shakespeare, Caravaggio, and the Indistinct Regard Rocco Coronato 


\section{Shakespeare, Caravaggio, and the Indistinct Regard}

\section{Rocco Coronato}

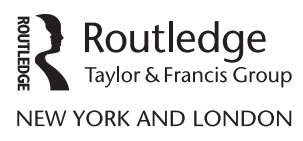


First published 2018

by Routledge

711 Third Avenue, New York, NY 10017

and by Routledge

2 Park Square, Milton Park, Abingdon, Oxon OX14 4RN

Routledge is an imprint of the Taylor \& Francis Group, an informa business

(C) 2018 Taylor \& Francis

The right of Rocco Coronato to be identified as author of this work has been asserted by him in accordance with sections 77 and 78 of the Copyright, Designs and Patents Act 1988.

All rights reserved. No part of this book may be reprinted or reproduced or utilised in any form or by any electronic, mechanical, or other means, now known or hereafter invented, including photocopying and recording, or in any information storage or retrieval system, without permission in writing from the publishers.

Trademark notice: Product or corporate names may be trademarks or registered trademarks, and are used only for identification and explanation without intent to infringe.

Library of Congress Cataloging-in-Publication Data

CIP data has been applied for.

ISBN: 978-0-8153-7634-7 (hbk)

ISBN: 978-1-351-23793-2 (ebk)

Typeset in Sabon

by codeMantra 
To Irene and Michele, my fixed stars 
This page intentionally left blank 


\section{Contents}

List of Figures

ix

Abbreviations Used

xi

Acknowledgments

xiii

1 Imagine

Shaking Spears 1

The State of the Art 4

The Status of the Image 12

The Indistinct Image 18

2 Still, Life

Birds, Grapes, and Girls 35

Caravaggio's "Tremenda Naturalezza” 39

Hunting for Metaphors: Shakespeare's Natura Morta 48

3 Dark Mirrors

Light in Darkness 64

The Pool: Narcissus 73

The Shield: Medusa 76

The Cloud: Hermes 82

The Vanishing Mirror 86

4 The Indistinct Regard

Caravaggio and Dispersal 110

Shakespeare's Starry Sky 119

How (Not) to See the Sea 132

Projection and Desire 139

Bibliography

Index 
This page intentionally left blank 


\section{List of Figures}

${ }^{*}$ " " "This photographic reproduction was provided by the Photo library of the Federico Zeri Foundation, Bologna, Italy. The property rights of the author have been met").

1.1 Caravaggio, The Taking of Christ (c. 1602). [*] 23

2.1 Caravaggio, Boy Bitten by a Lizard (c. 1596). [*]

2.2 Caravaggio, Basket of Fruit (c. 1596). [*] 44

2.3 Caravaggio, Young Sick Bacchus (c. 1593). [*] 45

2.4 Caravaggio, Bacchus (c. 1596). By permission of the Ministero dei Beni e delle Attività Culturali e del Turismo, Gallerie degli Uffizi

2.5 Caravaggio, Boy with a Basket of Fruit (c. 1593). [*]

2.6 Caravaggio, London Supper at Emmaus (c. 1602). By permission of the (C) National Gallery Picture Library, London

3.1 Caravaggio, Narcissus (c. 1599). ["]

3.2 Caravaggio, Medusa (c. 1597). By permission of the Ministero dei Beni e delle Attività Culturali e del Turismo, Gallerie degli Uffizi

3.3 Caravaggio, Jupiter, Neptune and Pluto (c. 1597). Public domain

3.4 Caravaggio, Penitent Magdalene (c. 1597). ["] 88

3.5 Caravaggio, Brera Supper at Emmaus (c. 1606). [*] 89

3.6 Caravaggio, Saint Matthew and the Angel (c. 1602). [*] 90

3.7 Caravaggio, Inspiration of Saint Matthew (c. 1602). [*] 91

4.1 Caravaggio, Madonna of Loreto (c. 1604). [*] 112

4.2 Caravaggio, The Death of the Virgin (c. 1601-1604). [*] 113

4.3 Caravaggio, The Raising of Lazarus (c. 1609). ["] 114

4.4 Caravaggio, Conversion of Saint Paul (1601). [*] 116

4.5 Caravaggio, The Calling of Saint Matthew (1600). [*] 117

4.6 Caravaggio, Martyrdom of Saint Matthew (1600). [*] 118 
This page intentionally left blank 


\section{Abbreviations Used}

All quotations from Shakespeare refer to William Shakespeare: The Complete Works (Oxford Shakespeare), second edition, by Stanley Wells, edited by Gary Taylor, John Jowett and William Montgomery, 2005. By permission of (C) Oxford University Press. When a quotation refers to the same text last quoted, the abbreviation is dropped.

AC Antony and Cleopatra

AW All's Well That Ends Well

AYL As You Like It

COR Coriolanus

CYM Cymbeline

HAM Hamlet

1H4 Henry IV, Part One

2H4 Henry IV, Part Two

H5 Henry V

1H6 Henry VI, Part One

2H6 Henry VI, Part Two

H8 Henry VIII

JC Julius Caesar

KJ King John

KL King Lear

LLL Love's Labour's Lost

MAC Macbeth

MADO Much Ado About Nothing

MM Measure for Measure

MND A Midsummer Night's Dream

MV The Merchant of Venice

OTH Othello

R2 Richard II

R3 Richard III

RJ Romeo and Juliet

RL The Rape of Lucrece

SON The Sonnets

TC Troilus and Cressida

TEM The Tempest 
xii Abbreviations Used

TGV The Two Gentlemen of Verona

TIM Timon of Athens

TIT Titus Andronicus

TN Twelfth Night

TSHR The Taming of the Shrew

VA Venus and Adonis

WT The Winter's Tale 


\section{Acknowledgments}

A preliminary study on beheading and painting ("Cephalophorus: Headcutting in Caravaggio and Shakespeare") was presented in 2013 at the IASEMS (Italian Association of Shakespeare and Early Modern Studies) Annual Conference Re-thinking Early Modern: Critical Approaches, organised at the University of Padova by Alessandra Petrina.

A paper on alchemy and Antony and Cleopatra, titled "Wafer-Cakes and Serpents: Melting the Symbol in Anthony and Cleopatra", was given in 2014 at the Congress Shakespeare 450 (Société Française Shakespeare, Université de la Sorbonne, Paris).

A preliminary part on blackness and Macbeth was first presented as a paper titled "Back in Black - Macbeth" at the XXVI AIA Congress, Remediating, Rescripting, Remaking: Old and New Challenges in English Studies, University of Parma, 12-14 settembre 2013, and then published as "Shakespeare's Camera Obscura: Macbeth and Blackness", in Remediating Imagination. Literatures and Cultures in English from the Renaissance to the Postcolonial, ed. G. Angeletti, G. Buonanno, and D. Saglia (Rome: Carocci, 2016), pp. 31-9.

"The Shield: Medusa" in based on an article that originally appeared as "The Charm of Decapitation: Medusa in Caravaggio and Measure for Measure", in Shakespeare and the Visual Arts. The Italian Influence, ed. Michele Marrapodi (Abingdon-New York: Routledge, 2017), pp. 178-93.

I thank the editors for the permissions to reprint these two articles in revised form.

I owe both much illumination and the beneficial advantages of chiaroscuro to the ongoing conversation I have shared on Shakespeare and all the rest with: Maurizio Ascari, Shaul Bassi, Francesca Balestra, Luca Biagiotti, Lucia Boldrini, Daniela Caselli, Linda Charnes, Jerome De Groot, Keir Elam, Carmen Gallo, John Gillies, Stephen Greenblatt, Farah Karim-Cooper, Denis Lagae-Devoldere, Geoff Lehman, Andrea Malaguti, Stefano Manferlotti, Yaakov Mascetti, Annalisa Oboe, Alessandra Petrina, Sharon Ruston, Anne Schoysman, Will Sharpe, Stuart Sillars, Michele Stanco, Erin Sullivan, Sara Trevisan, Roberto Venuti. 
Most of my research, generously funded by the DiSLL (Dipartimento di Studi Linguistici e Letterari, University of Padua), was carried out at the Warburg Institute (whose unrivalled bibliographic wealth is matched only by the warm cordiality of its staff), at the British Library, and at the University of London Library.

Giovanna Mochi witnessed the beginnings of this work and offered warm, informed encouragement throughout the project. I thank Michele Marrapodi, the Series editor, for his generous, constant support to this idea when it was still a serendipitous impression, and Henry Monaco for his editorial assistance. Bill Carroll offered invaluable comment on several methodological points. I am especially grateful to Kent Cartwright and Christopher Johnson, who kindly read an advanced draft and contributed many crucial remarks on its argument. 


\section{Imagine}

\section{Shaking Spears}

Discussing the three arguably most ubiquitous Latin words in literary criticism, ut pictura poesis, Shaftesbury puts them to short shrift and contends that "[c]omparisons and parallels" that "run between painting and poetry because of the pictoribus atque poesis etc. and the ut pictura poesis" are "almost ever absurd and at best constrained, lame, or defective". ${ }^{1}$ We can only wonder what Shaftesbury would have thought of a serendipitous instance where history itself nearly makes the case for simultaneity between the very best of painting and of literature: the near perfect overlap between the careers of Caravaggio and Shakespeare from c. 1592 to 1610 (the year Caravaggio died). Such a staggering synchronicity was not limited to chronology: Michael Fried noted a common trait in their sceptical doubt over the possibility of knowing the thoughts of another person's mind. ${ }^{2}$ Recent studies have further underlined Caravaggio's dislocation of the sense of history and the salience of doubt in interpretation, ${ }^{3}$ to the beneficial detriment of the twentiethcentury appropriation of Caravaggio as a transgressive codebreaker. I wish to prove that the comparison with Caravaggio casts, by contrast, new light (and shadow) on Shakespeare.

Obviously, I am not interested in influence but in confluence. Shakespeare and Caravaggio almost certainly knew nothing of each other. The earliest English allusion to Caravaggio only appeared in 1686 in William Aglionby's Painting Illustrated in Three Diallogues (unsurprisingly for neoclassical England, a scathing one). Unlike Titian, Caravaggio's paintings were less routinely spread through prints outside Italy, and only then after Shakespeare's death. ${ }^{4}$ The earliest reference to Caravaggio outside Italy occurs in Het Schilder-Boeck by the Dutch painter Carel Van Mander (1604; the manuscript probably dated back to the year before). Writing in Dutch, Mander alludes to a certain Michelangelo da Caravaggio, "who is doing extraordinary things in Rome", having "climbed up from poverty through hard work and by taking on everything with foresight and courage". Van Mander describes Caravaggio as a fauvish painter roaming about on the moonlit streets of 


\section{Imagine}

Rome, a provincial shake-spear in search of fame: "he does not study his art constantly, so that after two weeks of work he will sally forth for two months together with his rapier at his side and his servant-boy after him, always ready to argue or fight". ${ }^{5}$ On 28 May 1606, Caravaggio did use his weapon and wounded the painter Ranuccio Tomassoni with a fatal blow to his thigh. His 1610 death of a malignant fever at Porto Ercole for his contemporaries became the epitome of his eventful life: according to the rival Giovanni Baglione, Caravaggio suffered a death equally as bad as the life he had led ("morì malamente, come appunto male havea vivuto"). ${ }^{6}$

Yet my choice of Caravaggio does not rest on simultaneity alone. Despite their separation, in some moments, the two artists eerily seem to be working in the same studio, and not only in those frequent places where they adapt the same group of mythological figures, like Medusa or Narcissus. The similarity may stem from the same source (the episode of Caritas Romana in which Pero breastfeeds the father Cimon who had been sentenced to death by starvation, included by Caravaggio in The Seven Works of Mercy, 1607), ${ }^{7}$ and quoted in Timon of Athens (4.3.116-17); from the same symbolic place (the cave in the backdrop of The Burial of St Lucy, probably inspired by Dionysus' Ear in Syracuse, which recalls the den of Titus Andronicus); or from the use of similar symbols, the "painted banquet" (SON 47.6) of the Basket of Fruit (c. 1596). Some coincidences really make one pause: the skull portrayed in Caravaggio's St Francis in Meditation as held by the saint naturally recalls the gravedigger's scene in Hamlet, a striking reminder of the two artists' participation in a largely shared visual and symbolic culture. ${ }^{8}$

I suggest that both Caravaggio and Shakespeare adopt, in their own varied ways, "the indistinct regard", to borrow the expression with which the Venetians on terra firma endeavour to decode the naval manoeuvres of the Turks in Othello (OTH 2.1.41), a gaze deliberately fixed on multiplicity, indeterminacy, and indistinction. To define it, I need to consider first of all the state of the art in Shakespeare's England and the status of the image as a model for the definition of literature. I begin by saying what this regard is not: neither ambiguity nor indeterminacy.

Indistinction goes beyond the innately literary phenomenon of ambiguity so present in interpretation from Aristotle to Empson, often also studied as semantic indeterminacy ${ }^{9}$ or as rhetorical ambiguity. ${ }^{10}$ From classical ambiguity, indistinction draws the possibility of simultaneous, multiple meanings that make literature possible, yet it is rather focused on what apparently denies and defies speech and thought, the fleeting moments of change, conversion and self-knowledge captured by Caravaggio and Shakespeare in their use of symbolism, light, darkness, and contemplation. My usage of indistinction also decidedly steers clear of the deconstructionist belief that literary works are not only indeterminate, but also "commentaries on their own indeterminacy": ${ }^{11}$ on the 
contrary, the indistinct regard constitutes interpretation in exceptional moments of negation.

Scientific notions of indeterminacy are not deliberately used, either. This book does not mean to offer yet another literary, liberal appropriation of Heisenberg's principle of indeterminacy. ${ }^{12}$ It is true that the conditions of interpretation, as scientists say, may make it indeterminate or utterly impossible: what resists determinacy may thus be in itself or in observation, ${ }^{13}$ unintentional and linked with the glitches in historical reconstruction (past conditions now lost to us, or the influence of present intellectual concerns) ${ }^{14}$ Indeterminacy may also derive from overdetermination (having more than one determining factor) and underdetermination (falling short of having features by which to be determined). ${ }^{15}$ It is a sobering thought to posit that, alongside semantic and epistemic indeterminacy, there might be a deep metaphysical indeterminacy residing in the act itself of formulating a hypothesis itself, when "reality itself is poised between alternatives". ${ }^{16}$ The indistinction I try to reconstruct here, however, is not based on the conditions of observation: by way of centring the analysis on elements of indistinction in Caravaggio and Shakespeare, it argues that both artists make observation possible even in those extreme situations of negation.

Caravaggio and Shakespeare offer a fruitful interpretation in divergence. Such an effort acknowledges the caveats usually placed before dangerous crossings. In the next section, I will consider a crucial objection: the paucity of early modern English publications on art and architecture, and the reduced artistic output in post-Reformation England, would seem to attest to an antivisual culture - so, why use Italian art to analyse Shakespeare? I will list the many reasons for believing that art was heavily present in Shakespeare's imagination, though probably not thanks to specific paintings (many sins this book may have committed, but not the hardly unprecedented one of positing Shakespeare's knowledge of a determinate painting). First, however, a brief note on method is warranted.

Shaftesbury was right. Many comparisons between art and literature typically rest on an extended generalization over space and time that magnifies the apparent similarities and attenuates the differences. Once Mannerism, for instance, is enlarged by way of ever-extending metaphors, similarities do explode, even though a feature might be literally present in one art and only figuratively in another. ${ }^{17}$ Mannerism as the alleged artistic template and counterpart to Shakespeare had, indeed, its own mannerisms in recent critical fashion, yet it is in good company with other generalizations under the aegis of the unity of the arts, sanctioned by use but often rendered threadbare past their utility. ${ }^{18}$ Actually, the term maniera boasted a belaboured history and admitted of contradictory, negative applications. ${ }^{19}$ Is Mannerism (or the Baroque) really unique in sundering the link between art and truth and exposing the illusory nature of art in a moment of crisis and precariousness? ${ }^{20}$ 


\section{Imagine}

Those scholars who are fond of interacting between different media, Ulrich Weisstein warned, ought to reject the notion of influence and reason instead by way of analogy, carefully underlining the similarities between things otherwise unrelated. ${ }^{21}$ The warning against the "forced equations between specific features", that led Svetlana and Paul Alpers to find faults in those attempts, like Mario Praz's Mnemosyne, who traced a similar closing effect in both a cupola and the couplets of a Shakespearean sonnet, ought to be kept firmly in $\operatorname{mind}^{22}$. Yet, Caravaggio and Shakespeare nicely dovetail with the last patterning listed by Thomas McFarland in order of ascending irrelation and diffusion among the arts, that is, "[w]hen the inner logic of an intellectual emphasis leads to a similar disposition of metaphorical materials even when no influence is present". ${ }^{23}$ Instead of the application of universal notions (Mannerism or the Baroque) to the particular, I will stick to what Leonard Barkan admirably says about the statuesque reawakening of Hermione: "it would be rash to argue that Shakespeare invented [it] with a copy of Vasari at his side; rather let us say that we can shed light on Winter's Tale by a close look at the common ground here". ${ }^{24}$

\section{The State of the Art}

Apropos the common ground between painting and poetry, were there enough artistic images in Shakespeare's England to give him a model for the ut pictura poesis? Iconoclasts hyperbolically claimed that millions of souls had been damned by images used in place of religion, and not one soul "was won to Christ by having of images" 25 . For the Puritan William Perkins, even "a thing feigned in the mind by imagination is an idol". ${ }^{26}$ As early as in September 1538, the English priests were instructed to remove images against the detestable sin of idolatry in application of the Biblical caveat against image-making (Exodus 20.4-6); ${ }^{27}$ the 1559 Royal Injunctions, substantially repeating those issued by Edward VI in 1547, forbade, in churches and private homes, all "monumentes of faigned myracles, pylgrimages, idolatrie, and superstition". ${ }^{28}$ The injunctions also prescribed the daily showing of the written word alongside its recitation. ${ }^{29}$

Yet, recent critical accounts tend to read the agency of iconoclasm less sweepingly. Its application was hardly uniform across Protestant Europe, as exemplified by Luther's moderate support of religious art to Calvin's and Zwingli's harsh denial. ${ }^{30}$ Luther distinguished between the use and abuse of images, and Calvin acknowledged that the "historical" and "civil" use of pictures could be accepted "for instruction or admonition", and "fitted for amusement". ${ }^{31}$ Moreover, not even the most rabid iconoclast could forget that Christ had assumed human shape and that angels often took bodily form in the Bible. The condemnation thus came often to concern not "painting and image-making as wicked in and 
of themselves", but those narrative images that rendered the "processe of a story, painted with the gestures and actions of many persons", by way of "dumbe idols". ${ }^{32}$ Painting and portraiture that did not entail the worship of God could be allowed, and the depiction of historical events, the Medieval "story-work picture", was still permitted by the notorious anti-imagist William Perkins in $1598 .{ }^{33}$ Moreover, text and image jointly survived as means of contemplation in Northern European devotional works; in Lutheran art, the cross remained a sign of comfort and triumph against the fear of punishment, and images were still gazed at in prayer books in supplication. ${ }^{34}$ In this arguable shift toward secularization, the secular could be still compatible with the sacred, rebutting the notion that in Northern Europe access to the transcendent was blocked. ${ }^{35}$ Thus, some visual power still survives in the religious art of Protestant England: the image of "our Saviour, as an open book", reminds the viewers not only of the virtues they may learn but also of His cruel, painful passion, making them responsible for that crucifixion caused by their sins. ${ }^{36}$ Defacing as not a triumph of faith, but the annihilation of beauty, ambivalently transpires in Shakespeare, who applies it to ancient art (SON 64.1; JC 1.1.4), to man as the "precious image of our dear redeemer" (R3 2.1.124), and to creation, God's "handiwork" (4.4.51).

Moreover, the perils of unbridled visualization did not concern Protestants only, as proved by the condemnation of nudity in religious art and other violations of decorum often found in Catholic authors as well. Indecent images ran counter to Aquinas' justification of images as a means of favoring devotion: paintings might well be the books of the unlearned, yet even a scholar is more moved by the sight of a crucifix than by reading about the crucifixion. ${ }^{37}$ The worshipper's correct use, Thomas More remarks, is "not fixing his final intent in the image, but referring it further to the honour of the person that the image represents". ${ }^{38}$

A more serious objection to my argument is that Shakespeare's England, if not radically pruned out of all sacred images, certainly could not boast a visual repertory even remotely comparable to European culture, let alone Caravaggio's Italy. There is no way to circumvent the fact that the English iconographic output, not to mention its value, was modest by comparison. English engravings comprised mainly the woodcuts made by Hans Holbein for Coverdale's English Bible (1535) and occasionally included worldly subjects, such as Henry VIII in Council, put at the end of Edward Halle's Chronicle (1548); Holbein also devised three small anticlerical woodcuts that appeared posthumously in $1548 .^{39}$ Other notable works were rather sparse, fairly stylised, and often made by non-English artists, such as The Funeral Impression of Sir Philip Sidney by Marcus Gheeraerts the Elder (1576) and Simon van De Passe's portrait of Pocahontas (1616). Only from the mid-seventeenth century onwards did the practice of drawing achieve comparable diffusion. ${ }^{40}$ In 


\section{Imagine}

fact, many of the major achievements of English art came to light only when Shakespeare had entered the last phase of his career or even after his death. One of the most celebrated portraits of the Prince of Wales, dressed in hunting costume while aiming to deliver the coup de grace to a stag, by Robert Peake (c. 1551-1619), dates to 1606-7 at least; a series of portraits in head-and-shoulders format showing major sensitivity to individual character rather than to symbolism and generalisation came into being much later with Cornelius Johnson (1593-1661). To this later period also belongs the famous portrait of Sir Thomas Aston at the death-Bed of his First Wife by John Souch (fl. 1616-36), portraying with metaphysical gusto the deceased lady as both lying on her death-bed and alive. The constant presence of a European painter at Court was only later assured by Rubens, who first visited London in 1620-21, and by Van Dyck, elected court painter from 1632 to his death in 1641.

Various reasons have been adduced for this apparent English lack of interest in painting. Perhaps the absence of history-painting, the historia commonly taken in Italy as the peak of art and a parallel to heroic poetry, was due to a practical preference for cloth hangings and panelling in the harsh English climate. Other negative factors included the absence of religious patronage, Elizabeth's scant interest in art (except her own portraits ${ }^{41}$ ), and the Painters-Stainers' Company's notion of painting as a craft rather than a liberal art. It is not clear whether it was a cause or an effect of this scarcity, but Shakespeare often has his less intellectually versed characters crave simplified allegorical images (Fortune painted blind, H5 3.6.29-37), icons such as "the picture of Nobody" (TEM 3.2.129), "your hands in your pocket, like a man after the old painting" ( $L L L$ 3.1.18-9); or "this fish painted", as a prospective portrait of Caliban (TEM 2.2.28-9).

To make matters worse, if English art was limping along with considerable delay after her Italian sister and mistress, the "rare Italian master" (WT 5.2.96) was often rare in all senses of the word. When Jonson quotes in Discoveries the "six famous painters in Italy who were excellent and emulous of the ancients", he is merely borrowing from Possevino's 1593 Tractatio de Poesi et pictura ethnica, humana, et sacra. The presence of Italian artists was limited in Tudor England, and much of their work has not survived. In October 1512, the Florentine sculptor Pietro Torrigiano was commissioned the sepulchral monument of Henry VI and Elizabeth of York; Benedetto da Rovezzano was in charge of the (unfinished) tomb of Wolsey (1524); in 1521, Wolsey commissioned from Giovanni da Maiano four roundels in terracotta with heads of Roman emperors that were destined to Hampton Court. Painters included Toto della Nunziata from the Ghirlandaio's workshop, active in England from 1519, the author of still unidentified works such as five tables on biblical subjects at Hampton Court (1530), a depicted table of Calomiae (1538), and a table of the story of King Alexander 
(1541); the painter and stuccatore Nicolò Bellin of Modena in 1533 or 1537; and Bartolomeo Penni (Bartholomew Penny), active in the years 1530-45. Girolamo da Treviso, a painter influenced by Parmigianino and active in Bologna from 1525, was engaged as a military engineer by Henry VIII. Neither have survived the works of Vincent Volpe, hired by Henry VIII for decorative and topographical works, whose drawings perhaps included a bird's-eye view of Dover. Quite likely, many of these painters worked mainly on grottesche and the imitation of patterned stuffs and drapery for ornamental purposes. The only exception could be the scenes from the Passion in Wolsey's Closet at Hampton Court (1537) in the so-called "Confessionary", attributed to either Holbein or Girolamo da Treviso.

Englishmen could travel to Italy, of course, but when they did, at least in Shakespeare's time, they did not lavish too much attention on local art. In his History of Italy (1549), William Thomas nearly ignores contemporary art in Rome and instead describes "the beautifull thynges of the antiquitees". ${ }^{42}$ In the 1590 s, Henry Constable, a Catholic, frequently visited Italy, especially Rome, and left a sonnet dedicated to Hilliard where he merely quoted Michelangelo and Raphael. ${ }^{43}$ The French-born Isaac Oliver visited probably Venice in 1596; among the works he copied there was Veronese's Mystic Marriage of St. Catherine. Yet very little of this influence surfaced in his works, at least not before the Madonna and Child in Glory (c. 1605-17), perhaps inspired by Barocci's Madonna of the Clouds and Rubens's Madonna Worshipped by Angels at the altar of Santa Maria in Vallicella, Rome, and the Head of Christ (after 1610), a chiaroscuro stipple in the manner of Correggio. ${ }^{44}$ The Earl of Arundel visited Italy in 1612 (and perhaps earlier in 1609). The most important English Grand Tour took place only at the end of Shakespeare's career: on 18 April 1613, Inigo Jones left with Arundel for a tour of Italy that was to last more than a year and a half. Jones attested to the importance of design (disegno) in his Roman sketchbook (c. 1615) as a way "to maak a hoole figgur [...] and consequently a hoole Storry wth all ye ornamentes". ${ }^{45}$ A more regular frequentation of Italy starts quite late, for instance, with William Dobson (1611-46) in 1642; Sir Peter Lely (1618-80), the author of An Idyll perhaps in the 1640s; and the Catholic John Michael Wright (1617-1700?), who visited Italy and encountered its most distinguished artists.

What with the success of the Reformation in expunging public religious art and the national paucity of visual experience, the artistic repertory of Shakespeare's England would seem an iconoclast's best dream. Yet there are reasons to believe that the artistic landscape was not this destitute. First, the vocabulary of sixteenth-century England hardly distinguished between painting and sculpture. 'Picture' ambiguously meant image, rather than simply painting, ${ }^{46}$ it covered an eclectic range of visual works in minor arts. ${ }^{47}$ Shakespeare did not have to look any further for art: the 


\section{Imagine}

liberty of Blackfriars was home to many artists, and Southwark hosted the yards and wharves of stonemasons, tombmakers, and statuaries, such as Cornelius Cure (d. 1608) and his son William (d. 1632), together with Gerard Janssen, the sculptor of Shakespeare's monument at Stratford.

In its enlarged sense, also including the arts of ornament, art was still widely available in Shakespeare's England. Embellishment was a major trend of Elizabethan art and decoration in every medium. ${ }^{48}$ Arras were other providers of images "like the shaven Hercules in the smirched, worm-eaten tapestry" (MADO 3.3.133-34). Domestic wall painting served to give the illusion of hangings: the "painted cloths" were probably paintings in tempera on canvas introduced by early sixteenth-century Italian artists, and were also hung in the streets during royal processions. Many European iconographic motifs of mazes and knots resurfaced in English decorative arts as a result of the diffusion of prints on industrial scale. ${ }^{49}$ After his failed performance as Alisander, Nathaniel learns he will be scraped out of such a painted cloth (LLL . 5.2.570-71).

Art was also present in England under forms that were similar to its European counterparts. English artists were renowned all over Europe as portrait miniaturists. Orlando's face bears his father's image "[m]ost truly limned and living" (AYL 2.7.198): the practice of "limning" (the ubiquitous term for drawing and painting) had a close relation to manuscript illumination and was modulated in terms of idealisation. The painter Edward Norgate regards the three sittings required for the miniature as an "occasion of Discourse [...] wherein you must bee ready and suddaine to catch and steale your observations, and to expresse them with a quick and constant hand". ${ }^{50}$ The miniature was a natural expression of the ruling classes: Elizabeth increasingly came to favour its stylised, idealised, allegorical nature. ${ }^{51}$ The miniature implied, also for technical reasons, a poetics of its own: the style of artists like Hilliard, Peake, and Segar looked back towards the late Middle Ages and the early Tudor age. ${ }^{52}$

Pliny, part of the English scholastic curriculum, had stated that portraits helped "to continue and perpetuate the memorial of men". 53 Portraiture was arguably the type of painting that Shakespeare's contemporaries had most in mind. Picture-shops were present in early seventeenth-century London, with private collections and shops in the Strand, Fleet Street, Blackfriars, and St Paul's. These portraits required the imitation of both physical and psychological likeness: for the celebrated English goldsmith and limner Nicholas Hilliard, the utmost perfection lies in imitating

the face of mankind [...] so near and so well after the life as that not only the party in all likeness for favour and complexion is, or may be, very well resembled, but even his best graces and countenance notably expressed. ${ }^{54}$ 
All this, however, with the customary English paucity: a 1595 inventory of the pictures owned by an affluent English professional listed just his own portrait, a picture of the passion of Christ, "An Emblem of Love", and "Queen an bullayne". ${ }^{55}$ As to portraits of rulers, they were all over the place. Already under Henry VIII was portraiture connected with masculinity and magnificence. ${ }^{56}$ Thanks mainly to Holbein's presence in 1530s London, portraits of non-rulers and of the rising bourgeoisie were also available, albeit scarcely: for instance, Holbein's portraits of German merchants made between 1532 and 1536 and on display at the Guildhall up to 1598; on his visit to England in 1576, the Italian painter Federigo Zuccaro emphatically declared them to be on a par with Raphael. ${ }^{57}$

Such was the prominence of portraits that most references to art in early modern drama concern them. Portraits are vivid reminders of the subject's identity: the picture of Talbot would be enough to arouse fear in the French camp (1H6 4.7.83-4). Carefully preserved by a curtain, they offer a natural metaphor for the human face (TN 1.5.223). Portraits are brought on stage in The Two Gentlemen of Verona and in The Two Noble Kinsmen. The lamentable paucity of contemporary, reliable portraits of Shakespeare ${ }^{58}$ is only aggravated by the fact that his friend, the actor Richard Burbage, was also credited as an artist specialised in imprese (the devices in picture which bear a motto); only two works have been attributed to him, both small portrait heads, one of which is in Dulwich College. Portraiture also enabled artists to retain elements of classical art, despite the dislike or deep suspicion of many English Protestants for classical sculpture and Italian neoclassical architecture. Classical themes and influences were used for decoration, as some saw in classicism an alternative to the Catholic Middle Ages. ${ }^{59}$ Henry VIII's possessions listed a classical-sounding "table of antique" and "a boxe leather full of painted antiques", as well as a portrait of himself "lyke an antic"; classical sculpted busts were also referenced in painted and engraved portraits. ${ }^{60}$

As regards technique, English artists probably knew too little about the enormous achievements of Italian art, and the admixture of natural detail and symbolic readings so evident in miniatures can be found in full-size painting, too. Symbolism, often in a crudely allegorical, Medieval form, characterises the few paintings that survived from this period both because of their private provenance and non-religious subject matter. Hans Eworth's Sir John Luttrell (1550) encompasses the major events of the life of this soldier and merchant adventurer in an easily legible "allegory or pictorial metaphor". ${ }^{61}$ Facile symbolism also emerges in the Allegory of Edward VI and the Pope (c. 1575), commemorating the renewed Protestantism and the triumph of true faith under the iconoclastic Edward. ${ }^{62}$ Allegorical symbolism also underpins the portraits of Elizabeth, albeit gradually progressing from simplicity to enigma. ${ }^{63}$ 


\section{Imagine}

A c. 1600 procession of Elizabeth carried in a palanquin on the retainers' shoulders, attributed to Robert Peake, still captures the almost Oriental nature of her royal presence.

However, this does not mean that English painters did not experiment with new forms and techniques of artistic representation. While often looking back to the Middle Ages, Tudor Court painters follow techniques employed by European artists. Anamorphosis, a conventional painterly simile for perfection (SON 24.4-6), informs William Scrots' perspective portrait of Edward VI (1546). ${ }^{64}$ A fashionable melancholy came to dictate the mood from about 1590s onwards, namely in Marcus Gheeraerts the Younger and Isaac Oliver, though still smacking of allegorical symbolism as in the latter's Edward, Ist Lord Herbert of Cherbury (c. 1610). ${ }^{65}$ Isaac Oliver, though opting for a more realistic tinge, showcases the different shades and tones of melancholy in his Young Man Reclining Against a Tree (c. 1590-95). An ideal of spontaneity and vivacity, as if the portrayed subject had been realistically caught in conversation, emerged in the 1620s. Even at this late date, English art showed little evidence of having been influenced by Italy, as in the scarcely sophisticated 1621 wall paintings at Bolsover Castle. This general delay in English art, however, did not imply complete ignorance of the Italian Renaissance's synthesis of classicism, perspective, and design: an unknown artist's portrait of Henry Howard, Earl of Surrey (c. 1546), attributed to Scrots, proves that the appropriation of the Italian Renaissance was possible in art as well, with its reinterpretation of Roman antiquity and the garish display of precious finery and dress as signs of individuality.

Moreover, Italian art was by no means inaccessible in Shakespeare's England. The Charles I inventory for Hampton Court lists seven paintings by Giulio Romano and two by Parmigianino, together with fulllength portraits of Queen Elizabeth and the portrait of the Earl of Leicester made by Federigo Zuccaro in 1575. Giulio Romano was famous mainly for the lewd illustrations made for Aretino's I Sonetti Lussuriosi (1524) and the related woodcuts made by Marcantonio Raimondi, included in a 1550 Venice collection of Aretino's poetry and perhaps the "wanton pictures" filling the room where Christopher Sly will be carried to (TSHR Ind. sc. I, 45). Federigo Zuccaro is credited with full-length portraits of the Queen and the Earl of Leicester, whose drawings only have survived. ${ }^{66}$

Another way of spreading the images created by European artists was the circulation of prints. Titian was widely diffused: the appearance of Martius "as he were flayed" (COR 1.6.22) may refer to Titian's The Flaying of Marsyas, which was perhaps inspired by Giulio Romano's own, a painting that would later join Arundel's famed collection. ${ }^{67}$ Shakespeare's generic allusions to paintings do convey a Titianesque mythological aura, including the pictures to be offered to Sly and those secretly seen by Iachimo in Imogen's room. ${ }^{68}$ Titian's Venus and Adonis, 
like Shakespeare's poem, diverges from Ovid in presenting Adonis as a reluctant lover, which prompted Panofsky to wonder whether Titian influenced Shakespeare. ${ }^{69}$

Art connoisseurship was still in its infancy even in early seventeenthcentury Italy, and the English connoisseurship of European and Italian art unsurprisingly lagged behind. Yet, pictures were beginning to be collected and displayed in collectors' galleries and aristocratic homes, incipiently full of the "singularities" amassed by Paulina (WT 5.3.12). The collection of Henry Wotton probably included a portrait of an earlier Doge, perhaps attributed to Titian; The Four Seasons, probably by Jacopo da Ponte; and Prometheus devoured by his eagle, attributed to Giacomo Palma. The Lumley collection included Holbein's Duchess of Milan, his cartoons of Henry VII and Henry VIII, a book of portrait drawings, Eworth's portrait of Thomas Wyndham, and Antonis Mor's portrait of the Duke of Alva. Another important collection was Leicester's, which comprised at least two Venetian paintings, a Marriage in Venice (hung at Leicester House) and a Lady of Venetia (at Wansted). Religious paintings were left by John Donne to his friends; Lord Salisbury also owned several religious paintings, perhaps Italian, with a predominance of portraits. ${ }^{70}$ Haydocke praises the English aristocracy and their "Galleries carefully furnished, with the excellent monuments of sundry famous ancient Masters, both Italian and Germane" 71 . A new spate of acquisitions by English collectors started in the first decade of the seventeenth century, displaying a growing amount of expertise and counselling. The purchase of paintings by Palma Giovane and sculptures by Giambologna was advised by the Earl of Exeter to the Earl of Shrewsbury in 1609; by 1610, Inigo Jones had started to advise first the Earl of Rutland and then Arundel and the Prince of Wales. Prince Henry became a keen collector: his paintings included Palma il Giovane Prometheus Chained to the Rock, which had been acquired in 1608 by Wotton, ambassador in Venice. ${ }^{72}$ Other suitable venues of further acquaintance with Italian art might have been the saloons and galleries of Leicester's castle of Kenilworth. Leicester House hosted two Venus and Cupid, and another described as "a naked Lady sleeping and Cupid menacing her with his dart", a Diana depicted while bathing and a Diana and Actaeon, a picture of Occasion and Repentance at Kenilworth. More than half of the two hundred and twenty paintings owned by Leicester were portraits. If Shakespeare's company performed before the Queen at Nonesuch Palace at Cheam in Surrey, the residence of John, Lord Lumley (d. 1609), the most important English collector of pictures before the Earl of Arundel, to whom his collection was then bequeathed, a splendid gallery of historical portraits was there to be admired. ${ }^{73}$

Italian art was also present in English architecture and scenography: buildings, frontispieces, and churches betray leniency towards the 


\section{Imagine}

importing of Italianate architecture and classicism in sixteenth-century England. ${ }^{74}$ Interest in Italy was kept alive also in books such as Robert Dallington's Survey of Tuscany (1605) and Francesco Bocchi's Le bellezze della città di Fiorenza (1591). Some copies of celebrated works of Italian art prose, including Aretino's Letters, Vasari's Lives, and Cellini's Life, were already in England when Thomas James catalogued the Bodleian in 1605. Further circulation of Italian treatises on art could have been made possible through Italian book agents and private travelling gentlemen, such as Thomas Allen, who obtained Lomazzo's treatise for Haydocke. ${ }^{75}$ Thorough acquaintance with Vasari and Italian literature on art flourishes later with Edward Norgate, who in 1622 went to Rome and started to compose his notes on painting, later increased in 1648 and $1650 .^{76}$

The existence of actual paintings and images ought to attenuate all generalisations on the alleged antivisual culture of Shakespeare's England. More importantly, one thing is the material reality, quite another, the survival of the agency and persuasion long attributed to the image. The vocal denunciations of the power and danger of images in antivisual Protestant England may be a paradoxical proof of this survival, perhaps not (just) on the cloth or in the stone, but also in the mind. Even more important than this physical repertory of images, there lay the enormous wealth of the written descriptions of art that no iconoclasm or distrust toward the image could fence off.

\section{The Status of the Image}

Art was present primarily as a written description, or ekphrasis, in all early modern authors, including the Italians soaked in their exuberant wealth of images. Originally including several meanings such as descriptions of a person, place, or battle, ekphrasis, isolated as a scholastic exercise of describing a work of art, encouraged the creation of autonomous descriptions, not infrequently marked by a sterile proliferation of detail, and turned into a metaphor for poetry and for an audience's response to it. ${ }^{77}$ Repeatedly presented in schoolroom handbooks as a descriptive speech that shows the thing vividly before the eyes, ekphrasis fostered a sense of identification with the poet's experience, a visibile parlare that translated mute painting into speaking pictures. ${ }^{78}$ Thus generalised, ekphrasis becomes one of the rhetorical tropes that change the usual meanings of words and make the speech higher and more delectable. ${ }^{79}$ Ekphrasis was also often made to overlap with another canonical term, enargeia (or evidentia), originally defining the visual power of a literary description and eventually taken to indicate an "imaginative presence" that renders "absent things, events and persons mysteriously present and vivid through language" and made narrative seem probable. ${ }^{80}$ Enargeia, often equivocated with energeia, the activity or actuality of metaphor cited by Aristotle (Rhetoric 1411b-1413a), had, by the late sixteenth 
century, also shifted from a virtue of ornament to a quality of style. ${ }^{81}$ Like ekphrasis, enargeia becomes a hallmark of good literature exactly by purporting to be an image. Chapman praises "Enargia, or cleerenes of representation" as the "harty inuention exprest in most significant, and vnaffected phrase", similarly to a skillful painter who does not "draw the figure of a face onely to make knowne who it represents; but hee must lymn, giue luster, shaddow, and heightening". ${ }^{82}$ Ekphrasis and enargeia illustrate the Renaissance relish for copiousness and accumulation (copia) as two devices of ornament in amplification. ${ }^{83}$ The same Chapman equates liveliness with ekphrasis and more generally with poetry in his praise of Achilles' shield, the earliest and most celebrated example of ekphrasis, as an instance of how the divine poet describes all things as if they consisted "not of hard and solid mettals, but of a truely liuing and mouing soule". ${ }^{84}$ All this in the effort to make the invisible visible: eloquence counts among its chief ornaments the tricks used to amplify and to illustrate, and "how can you commend a thing more acceptably to our attention than by telling us it is extraordinary and by showing us that it is evident?". ${ }^{85}$ Copiousness makes style vivid, and this visuality renders the invisible: W.J.T. Mitchell traces this shift toward the visibility of the invisible, or the pictorial turn, already in Plato's allegory of the cavern and its exaltation of the light of reason. ${ }^{86}$ One striking example of the power of ekphrasis on the early modern stage is the usage of miniatures. Shakespeare presents them as examples of divine perfection, as in the small-size portrait of Portia, coming so "near creation" ( $M V$ 3.2.116), or in King Hamlet's "picture in little" (HAM 2.2.367). Those miniatures, like the ones of King Hamlet and Claudius, remained completely invisible to the audience because of their smallness and yet they subsisted thanks to their description, as a fittest testimony to the power of the written and spoken image.

A further influence was Italian art theory, whose high status across Europe included England thanks to vulgarisations like A Tracte Containing the Artes of Curious Painting (1598), Richard Haydocke's translation of Paolo Giovanni Lomazzo's Trattato dell'arte della pittura (1584). ${ }^{87}$ In the case of Lomazzo, we have clear textual proof; in many others, we sense a communal belief in the power of the image as a model for poetry. In February 1564, reading a lecture in Florence commemorating the recent death of Michelangelo, the Italian Lionardo Salviati contends that the best writers convey the mysteries of divine things by casting a veil of ambiguous words ("velandole di dubbiose parole") to make them more delectable and wonderful; nonetheless, painting offers the words directly to the eyes and, with its divine artifice, unveils their discourse ("con divino artifizio ne discuopre i parlari"). ${ }^{88}$ In Salviati's paradox, the rival arts strive to outsmart one another by mutual appropriation: words are powerful when they show things veiled, and art is poignant when it gives voice to images. A similar interplay of occlusion 


\section{Imagine}

and completion transpires in the "imaginary work" that Lucrece sees in the painting of the Fall of Troy, where much is "left unseen, save to the eye of the mind", and each part of the bodies "[s]tood for the whole to be imagined" ( $R L 1423,1425,1527) .{ }^{89}$ Most certainly, Shakespeare did not know the passage that Salviati had delivered a few months before his birth in 1564 . Had he read it, however, he would have immediately recognised the same terms of imitation and rivalry set in motion by a millennial tradition on the primacy of sight, as both the highest sense and the best representation of knowledge.

The eye does not see itself: this simple natural fact had long been iterated since Plato (First Alcibiades 133A) and Cicero (Tusculan Disputations i.28). Shakespeare often recalls this paradox: the eye, "the most pure spirit of sense", cannot "behold itself, / Not going from itself" (TC 3.3.101-102). For sight is also, by tradition, the most piercing of the senses. Nowhere does the universal desire to know shine more, argues Aristotle, than in the delight given by our senses and especially the sight, which we prefer in itself to anything else (Metaphysics Book A, 980a, 21). Sight explains for Gombrich the difference in Plato between the intelligible world of the spirit and its imperfect reflection, this world, or, correspondingly, knowledge through vision and through discursive speech, respectively. Because of its immediacy, seeing becomes " $\mathrm{a}$ favoured symbol of higher knowledge". ${ }^{90}$ Paulina similarly hopes that showing the silent image of newborn Perdita may persuade Leontes better than speech (WT 2.2.40-41).

Being the most powerful sense, sight is also the nearest approximation to what happens in the mind. For the thinking soul, says Aristotle, images replace direct perceptions: the soul never thinks without a mental image (De Anima III.7.431a). Shakespeare similarly extols the "imaginary puissance" (H5 Prologue, 25) that completes art: Venus proves "[a]ll is imaginary" (VA 597), and Lucrece's "heavenly image sits" in Tarquin's mind ( $R L$ 288). The image conveys absolute presence: it purports direct access to the world eliding the distinction between subject and object, and overrides the hiatus between representation, fraught with the cultural and ideological context, and presentation, the presence of the visual object. ${ }^{91}$ The power of the images over the imagination transpires in the ancient rhetorical cultivation of fantasiai, or visions, and in the connections traced between imagination and the emotional impact of poetry. ${ }^{92}$ In the customary division of the mind in the three ventricles of the brain, imagination was supposed to be produced in the foremost cell, reason being instead made in the middle and recordation and mind in the hindermost. ${ }^{93}$ Avicenna posited imaginatio as a kind of memory, a faculty that retains the sensible forms received through the senses by the sensus communis, even after the disappearance of those sensibilia. ${ }^{94}$ The nexus between sight, light, reason, and truth persists in the Renaissance: divine truth, claims Ficino, is to be pursued, and 
reason was formed for that purpose, just as the eye was formed to catch the sunlight. ${ }^{95}$

The image also captures the invisible, both in the heavens and in the soul. The Medieval prominence of the visual owes much to the Platonic ideal of contemplation of God (thêra theou) and the vision promised in the Beatitudes. ${ }^{96}$ The three kinds of vision posited were the corporeal, the spiritual, and the intellectual, which discerns the spiritual images and grasps abstract entities. In meditation, physical images are seen by the eyes and transformed by the soul, which is thereby turned to God. ${ }^{97}$ According to Neoplatonism, what pleases the soul must be incorporeal, a representation not based on sense perception. ${ }^{98}$ Sight also manifests the invisible in the lover's soul: Castiglione compares the act of loving to an exchange of spirits through the eyes, a suave hitching where each lover takes on the other's quality. ${ }^{99}$ Cupid is accordingly depicted with wings because "the louer sendeth continuall beames of the eie towards that which he loueth", just like arrows. ${ }^{100}$ In hermeticism and love poetry, vision causes ligation (fascinatio), and images infuse their virtues by sympathy, a "witchcraft by a picture" as in Donne's poem.

An odd consequence of the primacy of sight is that imitation (and thus art) is praised depending on how powerfully the visual captures the invisible. Pliny the Elder (Natural History XXXV.98) quoted the painter Aristides of Thebes as the first to express the mentality (animus), sentiments (sensus), character (éthe), and passions (perturbationes) of a person. Shakespeare's Poet analogously praises painting as a speaking artefact: "What a mental power / This eye shoots forth! [...] To th' dumbness of the picture / One might interpret" (TIM 1.1.31-2, 33-4). ${ }^{101}$ The image is the best, closest rendition of the mind or the soul. Art is a perfect imitation, a second, divine nature, "life as lively mocked" (WT 5.3.19), "another nature" (CYM 2.4.84). It is excellent because it is a re-presentation: it makes the invisible present again. To the point of innatism: for the Italian Girolamo Ruscelli, the principle of representing through the sense of sight the figure and shape of things was produced by nature itself in the human mind and is more natural and common than hearing. ${ }^{102}$ Leon Battista Alberti compares perspective to the act of seeing through a window, and thus formalises the act of seeing as being based on a picture: the painter has to view the rectangular frame of the painting as an open window, translating "the three-dimensional view from outside an enclosed space onto a two-dimensional surface inside". ${ }^{103}$ In sacred painting, the image also forcibly conveys the presence of the object of vision in its materiality, together with its contemplativeness. ${ }^{104}$ Writers also endorse this power of the image and strive to emulate it. Puttenham defines the figure Icon as "resemblance by imagerie or pourtrait" that likens a human person and his or her parts or qualities to any other living creature or natural thing, just as a painter "yeldeth to th'eye a visible representation of the thing". ${ }^{105}$ Literature only claims to 
offer the best picture, but picture it still is. Poetry is the choice representation of the mind because it shows "the speaking picture of the mind, / The extract of the soule that laboured how / To leaue the image of her selfe behind". 106

The many echoes of Horace's ut pictura poesis becloud the extent of mutual animosity and fight for excellence between the two arts. The fight between the senses, an ancient commonplace with innumerable variations, exceeds the single competition between individual painters or writers and is institutionalised through systems like the seven liberal arts and the birth of academies. ${ }^{107}$ The debate focuses rather on whether painting or poetry better embodies the power of the visual in representing the invisible. In this fight, painting nearly always wins. Ben Jonson calls it "the invention of heaven", a "silent work" that yet "doth so enter and penetrate the inmost affection [...] as sometimes it o'ercomes the power of speech and oratory". ${ }^{108}$ The best compromise that poetry can reach is a cautious division of the work. Simonides' celebrated aphorism that painting is mute poetry and poetry a speaking picture, as reported by Plutarch (De Gloria Athenensium III.346f-347c), constantly rings out in the Renaissance, even though Plutarch quotes Simonides three times, and the other two partially qualify and diminish the power of this saying. Echoing this fortunate commonplace, Italian art theory often argues that painting renders the body, poetry the soul. ${ }^{109}$ Sidney similarly defines poetry as a "representing, counterfeiting, or figuring forth - to speak metaphorically, a speaking picture". ${ }^{110}$ The painter imitates all that is manifest to the eye by means of lines and colours, whereas the poet, by dint of words, imitates that which is manifest to the intellect ("si rappresenta all'intelletto"). ${ }^{111}$ Painting is mute poetry and thus praiseworthy. ${ }^{112}$ Painting and poetry, respectively, represent inward forms ("il di dentro", the soul being the province of the poets) and outward ones (the body, "il di fuori", reserved to painters). ${ }^{113}$ In this rivalry between the senses, inwardness is assigned to poetry, for the eyes "draw but what they see, know not the heart" (SON 24.14).

Rivalry implies closeness. "Imitari is nothing", and any artist is just "the ape of form" (LLL 4.2.126, 5.2.325). The artist is a simia naturae: painting and poetry share their intimate union because they both rest on the imitation of nature. A substantial unity in nature, content, and purpose between visual and verbal representations already appears in Aristotle's Poetics I-II. Imagination (phantasia) is common to painting and dramatic poetry, says Philostratus in his Imagines (390K), a series of descriptions of paintings written in the third century A.D. and one of the few extant ancient treatises in art. The primacy of the visual also influenced rhetoric. In Aristotle's list of the three ways of creating belief (Rhetoric 1358a2-4), logos (reason), ethos (self-presentation), and pathos (emotion), the poet is required to visualise the events described by assuming the same natural talents featured in those who experience 
those emotions (Poetics 17, 1455a29-31). Ancient rhetoric also employed many intersensory metaphors deriving from visual experience, which were revived by humanists, for instance, when describing diction as translucidus. ${ }^{114}$ For instance, colour is a common metaphor for the ornaments of speech and its effects, the apt use of words and plausible, lifelike fiction as opposed to lifeless line drawing (Aristotle, Poetics II.1, VI.19-21; Cicero, Orator xix.65; Plutarch, Moralia 16c). ${ }^{115}$

Occasionally, the order of excellence is overturned, understandably enough by poets. The literary pretence of best representing the image of the mind did not agree to recede graciously. ${ }^{116}$ Shakespeare often alludes to the superior power of poetry, for instance, when, in a chronological twist, he mentions Adonis, a conventional subject of Renaissance paintings, whose "counterfeit / Is poorly imitated" after the beauty of the young friend (SON 53.5-6). Vindicating the power of the ear and thus of drama, Thomas Heywood maintains that a description is only "a shadow received by the eare but not perceived by the eye", and portraiture is only "a forme seene by the eye" that "can neither shew action, passion, motion, or any other gesture, to moove the spirits of the beholder to admiration", unlike a "lively and well spirited action". ${ }^{117}$ Revealingly, while dismantling the excellency of painting, Heywood extols drama by still resorting to a visual expression ("shew").

This primacy of sight was even more striking in a moment when optical theories were being thoroughly revised. To quote Baxandall, each culture has its own "period eye", a cognitive perception that is culturally conditioned. ${ }^{118}$ When Kepler observed the solar eclipse on 10 July 1600 by means of a camera obscura, he began to rediscover the principle, already anticipated by the work of the Arab scientist Alhazen (Ibn al-Haytham) and of the Italian Francesco Maurolico, that the image on the wall of the camera came from the superposition of the conic beams issuing from the object and passing through the hole. In Ad Vitellionem Paralipomena (1604), Kepler extends this principle of reflection to the eye; the image, no longer projected by the eye, is contrariwise a reflection on the back of the retina: as picture, thus vision (ut pictura ita visio). ${ }^{119}$ Kepler's insight offers a sharp turn from the gradual projection that in Augustine marks the movement from the trace and the vestige to the image and finally to man as an image of God, though in his finitude. ${ }^{120}$

The power of the image is extolled to the point of reverting in its opposite, an indistinct zone occupied by what subverts the image and deletes all degrees and ranks. Albeit working from opposite perspectives, both iconoclasm in its varied application and the poetic of ekphrasis in its many specifications allay a distrust towards the image and its mimesis, an insistence on "the power of visual images to move observers to act, the fallibility of the sense of sight, and the relationship between visual perception and knowledge". ${ }^{121}$ The poignancy of the visual often implies this double movement: first, it extols the power of the eye ("there 


\section{Imagine}

is nothing so litle, that hath such diuersitie of operations attending it; being moued by the obiect that it looks vpon, to loue or hate") and then it argues the need for its temperance, as "[p]assions of the minde receiue their greatest impression by the eye of the bodie". ${ }^{122}$ The enemies of theatre analogously scourge the power of images to wreak havoc in the viewers' soul, in an unwitting praise of the mimetic efficiency of drama: the "lively, if not reall pictures and representations" are "so artificially acted on the Stage, that a man can hardly difference the representations of them from the sinnes themselves". ${ }^{123}$

It is my point that noticing the difference between things and their representations gradually evinces a poetic of the indistinct in both Caravaggio and Shakespeare. Both artists differently point to the obverse of the powerful image, a zone of indistinction where representation is centred on the suspension of hierarchy, beginning with the requirement for completeness.

\section{The Indistinct Image}

Even Venus profits from being left partially indistinct. The German educator Johannes Sturm quoted Apelles' painting of the goddess rising out of the sea as an example of how all imitators need to practice variety also by leaving some parts unfinished: just as Apelles "left some part of that picture rude and untrimmed, so likewise ought a writer and imitator to do, and to consider not how far a thing may be beautified and set forth, but how much polishing is meet therefor". ${ }^{124}$ Shakespeare often alludes to a more radical incompleteness of the image. He was not alone: to adapt what Karsten Harries says on perspective, a "distrust of the eye" characterised the emerging modern understanding of reality, ${ }^{125}$ in a period marked by "an increasing sensitivity to duplicity in images" and to the incorporation of the dismantling of the image in the artistic enterprise. ${ }^{126}$ In yet another serendipity, Shakespeare's career roughly spans the passage from the ancient theory of extramission (the image is created through the rays projected by the eye and reflected by the objects) to intramission (the rays emitted by the objects are reflected, and inverted, in the retina) and to the modern conception of sight, which entailed a more general "confused and muddled state of affairs". ${ }^{127}$ It was also a passage from a theory in which internal archetypic schemata are projected by characters onto the world, to one where objects convey an image similar to the schemata and to their representation. ${ }^{128}$ The same period also marks a dissociation between the knower and the known, even questioning the divine omnipotence in suspending their correspondence. ${ }^{129}$

The contemporary shift in optical theory and its numberless metaphorical applications may perhaps give sense to the frequency with which the eminently visual Shakespeare often questions sight. If "[b]eauty is bought by judgement of the eye" ( $L L L 2.1 .15)$, the revelation of truth 
often implies hanging conjecture on the eyelids (MADO 4.1.106). The primacy of sight is overturned: the image adheres to "but outside" (TIM 1.1.163), the exteriority that false eloquence captures with its "painted flourish" ( $L L L 2.1 .14)$. Especially the most iconic characters demand a silent rhetoric: King Hamlet asks for the son's "serious hearing" (HAM 1.5.5), and the misshapen Richard III ironically moralises on the discrepancy between form and truth, for the "outward show [...] [s]eldom or never jumpeth with the heart" (R3 3.1.10-11). Shakespeare juxtaposes this incipient distrust of the image with the impossible effort to capture "the heart's still rhetoric disclosèd with eyes" (LLL. 2.1.229). The most indeterminate representation of female beauty undermines the Titianesque imitation of nature, like Cleopatra "[o]'er-picturing that Venus where we see / the fancy outwork nature" (AC 2.2.207-208), or simply remains undescribed like Desdemona, who "paragons description and wild fame" (OTH 2.1.63).

The image is also linked with inane reflection and mortality: the more perfect the image, the more lifeless and mindless. The Troubadoric and Petrarchan idolo d'amore often turns the loved image into a threatening fetish. Proteus falls in love with Silvia after having beheld her image, ready to "worship shadows and adore false shapes" (TGV 4.2.127). One of the worst fates that can befall a Shakespearean character is the transformation of the self into an image, "vilely painted" as a sign (MADO 1.1.247), upon a pole with an impresa underneath it as with Macbeth, published as with Edgar or simply turned, like the disgraced Hermione, into "her without-door form" (WT 2.1.71). The dullness of the image attends the hero if he does not act with honour, "no better than picture-like to hang by th'wall" (COR 1.3.10-11). Deranged Ophelia proves that without judgement "we are pictures" (HAM 4.5.84).

"Avaunt, perplexity!" (LLL 5.2.298). In Shakespeare, the power of the image hardly gets proclaimed without recalling that it is a mere reflection of the subject, a deceiving counterfeit, a distant replica of life and nature that ultimately besets the mind with perplexity, a notion that exceeded simple puzzlement. Augustine sees in perplexity one of the features of human nature after the Fall, especially in the soul that is not directly turned toward God, in the antinomy between body and soul, the law of the flesh (lex membrorum) and the law of the mind (lex mentis), expounded in Paul (Romans 7.20-24). ${ }^{130}$ In Shakespeare, perplexity is a riddler that marks a catastrophic moment of loss and indecision, an ubiquity that resists interpretation, "here and everywhere" (TN 5.1.224). It befits tragedy (Othello is "perplexed in the extreme", OTH 5.2.355), but it also marks Launcelot's divergence between the duty to fly the devil Shylock and the loyalty to his master (MV 2.2.21-6).

It is this vast area of limits beneath the power of the image that fuels my cross-analysis of Caravaggio and Shakespeare. I have chosen 'indistinction', instead of indeterminacy, vagueness, or polyvalence, because 


\section{Imagine}

Shakespeare seemed to assign it a particular encompassing magnitude especially in connection with the gaze, as I hope will become clearer in the following chapters. However, this is not meant to deny the mobility and fluidity of its cognate terms: Richard Huloet's 1572 dictionary indifferently (literally) lists Indifferencie or equalitie, Indifferente, and Indiuisible, or not partable (Indistinctus). ${ }^{131} \mathrm{My}$ notion of 'indistinction' is indeed based on three aspects often intertwined in Shakespeare's works: multiplicity, indeterminacy, and indistinction itself. All the three terms occur prevalently in a negative sense, and yet they also serve to describe the most tenuous and sublime workings of the mind, of the soul and of divinity. They capture an area of negation that I find to be central to Caravaggio's and Shakespeare's artistic endeavours.

Multiplicity is a commonly negative term in Shakespeare. ${ }^{132}$ The phenomenon may recall the notion of vagueness in logic, linked by Bertrand Russell with multiplicity: a representation is vague when "the relation of the representing system to the represented system is not one-one, but one-many", and it often derives from the transposition of language onto the world. ${ }^{133}$ Having a "multitudinous tongue" and a "bosom multiplied", for instance, the Roman populace is a many-headed Hydra incapable of "interior survey" (COR 3.1.159, 3.1.134, 2.1.39). Yet, it is often presented in ambivalent terms. It both embodies the tendency to chaos, congeries, and accumulation that inevitably produces indistinction, and extols the fruitful liberality of nature and the imaginative agency of the human mind. Multiplicity conveys also the divine. Ficino's interpretation of Plato's Ion posits the descent of the soul from the One above Eternity down into eternal multiplicity ("eternam multitudinem"), and thence into time, place, and matter. For Aquinas, God, the cause, is one, but is found in the effect as composite and multiple; He introduced his likeness most perfectly in all created things, and thus the One created multiplicity and variety (Summa Contra Gentiles II.45.2).

The second component of indistinction in Shakespeare is indeterminacy - hardly the modern one I have decided not to use. Etymologically, the indeterminate is what yet lacks determination, the Latin terminus, the conclusion, a sense also present in 'indefinite' (that which has no end, finis). This sense of conclusion (or its lack) lingers in Shakespeare, where 'determinate', 'determined', and 'determine' (verb) focus on the conclusive, decisive, fixed, limited nature of the action. ${ }^{134}$ Thus, the revolving fortunes of a military siege are plagued by the "undetermined differences of kings" (KJ 2.1.355). The indeterminate is what has (yet) no conclusion, a temporary step in a process. On an irreconcilable point, the real presence of Christ in the Eucharist, 'indeterminate' returns in a negative sense: Harsnett accuses the Catholics of going even further than "Platoes Idaea of an essence substisting in nature, without existence in indiuiduall substances", all the "sensible accidents [...] made pendulous in the ayre [...] or els stript from their 
proper substance, and adhere to an indeterminate, vagrant, vnbounded being". ${ }^{135}$ Yet, like multiplicity, it indeterminacy boasts a glorious place in philosophy. Analysing the mixture of the Same and the Other with the substance expounded in the Timaeus (29d7-47e2), Plutarch comments that it "doth determine plurality, and limit out an end to that which is infinit, to wit, the binary or two indeterminate"; as duality is the "indefinite and indeterminate principle", the power of the Other divides the Same into many parts, resulting in "a plurality of worlds caused by The Other, that is to say, by Diversitie". ${ }^{136}$ Notions of indeterminacy are also applied to the mind and the divine. The distinction between 'determinate' and 'indeterminate' concerns the workings of memory, which operates "vppon a thynge apprehended or taken from ells where, vppon the acte by the whyche the same thynge was from ells where apprehended, and vppon the determinate or indeterminate tyme in the whyche the same apprehension was made". ${ }^{137}$ Freedom of will similarly leaves our fantasy not "determined, but [...] extended to many and almost infinite things"; thus, fantasy is also "undetermined", which often causes erring, especially "in matters diuine and immateriall". ${ }^{138}$ In theology, indeterminacy rules the relationship between free will and divine prescience: how to reconcile natural contingency and especially free choice, which are yet indeterminate, with the fact that the future individual events are already known by God and therefore determined? Aquinas' answer is that the whole course of time is spread before God's one, simple observation (intuitum): his knowledge of individuals covers all those particulars still not existing, future contingent events, and acts of human will, without implying determinism. The indeterminacy of future human choices and actions is already seen by God but not determined by his vision. ${ }^{139}$ Indeterminacy also regards the adiaphora, the indifferent things of faith that could be left undetermined.

The third component of the indistinct regard, already present in its name, is the indistinct, what cannot be defined because it fails to show differential marks of identity, often disposed over a continuum. The indistinct is both the result of this lack of definition and the main objection against order, an agency that undermines those notions and conventions that made order arguable. Shakespeare's Ulysses introduces a physical image to render the refinement and sedimentation through which distinction eventually manifests itself and "what hath mass or matter by itself / Lies rich in virtue and unminglèd" (TC 1.3.28-9). The indistinct marks the absence of those traits of difference that both create hierarchy and make it discernible. It also regards the hierarchy of the Chain of Being and especially the middling place of man in it, a distinction increasingly challenged by exceptions and subjected to the human ability to swerve from the law of God. ${ }^{140}$ Yet, like the two previous terms, indistinction is not necessarily a negative term. It appears, for instance, in theology to denote participation of the divine and human nature in 


\section{Imagine}

Christ, who "became perfect God and perfect man, hauing two distinct natures, substisting in one indistinct person". ${ }^{141}$

Most of the times, it is a fluid relationship: the presence of multiple states causes indeterminacy; conversely, the absence of determinacy may be represented through the abundance of states underneath the same element (for instance, the nuances between light and darkness, and the usage of darkness as a new light, in Chapter 3). Another typical example is, in Caravaggio's early paintings (Chapter 2), the multiplicity of natural symbols and their translation into the subject. The indistinct may refer both to the lack of ranked differences (the sky and the sea that give no shelter, respectively, in Hamlet and in The Tempest), and to the projection of this indistinct quality onto the gaze itself (Chapter 4). I hope to prove that indistinction ultimately includes multiplicity and indeterminacy and is thus the best recapitulation of the new form of representation that emerges in both Caravaggio and Shakespeare. The indistinct regard imposes uniformity on these multiform appearances I am quoting neither Heisenberg nor Derrida here but the Elizabethan rhetorician Puttenham, who argues that "well-affected" phantasy is not disorderly or confused, but "very formall, and in his much multiformitie uniforme". ${ }^{142}$ The well-crafted heroic poem, says Tasso in his Discorsi del poema eroico (1594), contains a great variety of matters and yet is "one in form and soul", all of its elements combined in mutual correspondence: "Multiplicity produces indeterminacy, and this progression could go on ad infinitum, unless art fixed and prescribed limits". ${ }^{143}$

Husserl posited indeterminacy as an ineradicable element of perceptual experience even within the claim of philosophy as rigorous science; a "zone of indeterminacy" resists surrounding the perceptual field, remaining "necessarily" there as a "residue". ${ }^{144}$ The indistinct regard proudly embraces these residues no longer as accidents or residuals of the act of creating order, but as a new order. I have also found a growing similarity between this notion of the indistinct and what Giorgio Agamben defines the "state of exception", a threshold of indeterminacy between democracy and absolutism that is also inscribed within the order of literature, a zone of suspension and anomie where all distinctions are deactivated, needed by law and literature to ground their reference to the world of life. ${ }^{145} \mathrm{I}$ also find the indistinct to be akin to that sense of disruption and discontinuity (déchirure) that George Poulet, in his study of the pensée indeterminée, traced in Montaigne and Shakespeare, where the reader, used to the uninterrupted line, held together by an essentially determined action, is thrown into "l'indétermination", into the unknown ("inconnu"). ${ }^{146}$

One may adapt for this poetics of the indistinct what Bassanio says about beauty without speech: it is a shadow that does "limp behind the substance" (MV 3.2.129). As John Davies stated in Nosce teipsum (1599), "my self am centre of my circling thought, / Only myself I study, 
learn and know". ${ }^{147}$ Indeed, the indistinct regard directly concerns the notion of the early modern subject. The term derives from subjectus, what is subordinated and placed under in logics, for instance in Porphyry's tree, as the structure that enables us to see the different species stemming from the general ousia, the essence, in a hierarchic vision that places the general above and the particular below. ${ }^{148}$ The indistinct subject obviously diverges from early modern notions of the uniqueness and variety of the individual enhanced by ancient and modern biographical models. ${ }^{149}$ As I explain in my conclusion, the indistinct regard is a projection that enables the subject to see its own vanishing, leaving the scene as Caravaggio's Jesus in The Taking of Christ (1602) (Figure 1.1), or accepting supreme indistinction like Hamlet.

Three phases are commonly distinguished in Caravaggio's career: from his likely arrival in Rome around 1592 and his work at the Contarelli and Cerasi chapels (1598-1602); from the first great works of his maturity until mid-1606, when he was forced to flee from Rome because of the killing of Ranuccio Tomassoni; finally, his last three years of vagrancy in Naples, Malta, and Sicily until his death in 1610 . The original plan for this book roughly followed the chronological order of Caravaggio's career and juxtaposed it with similar phases in Shakespeare's works. As my analysis progressed, however, this tripartite structure in fact

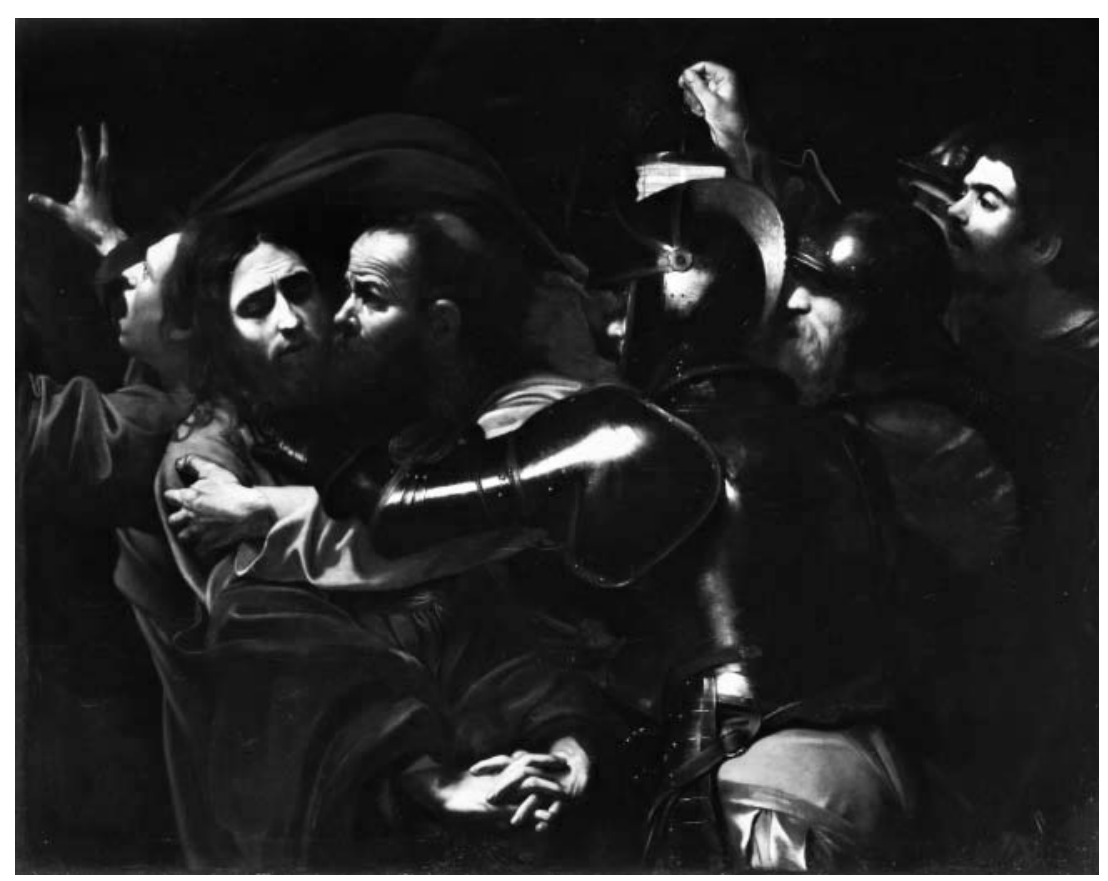

Figure 1.1 Caravaggio, The Taking of Christ (c. 1602). ["] 


\section{Imagine}

unfurled a more interesting one based on symbols, light and darkness, and the human body. I was pleased to discover that this triad egregiously unveiled Shakespeare's drive towards the indistinct without forcing the temporal constraints or imposing unnatural similarities.

In Chapter 2 ("Still, Life") I consider the usage of natural symbols in Caravaggio's still-lives and other early paintings and in Shakespeare. In Caravaggio, the subject, with a centripetal shift, gradually subsumes in itself the change in nature that tends to indistinction, peaking in the Suppers at Emmaus where Jesus is the subject who both causes and recognises change. Change similarly shifts in Shakespeare from the symbols to their indeterminate multiplicity as elements of fictional fluidity. In the simultaneity of incongruous, indeterminate states, characters like Falstaff and Iago lend new voice to the consciously indistinct.

Chapter 3 ("Dark Mirrors") joins two elements of late Renaissance poetics, the symbolism of light and darkness, and the mirror. Caravaggio famously tackles darkness by making it a second light that allows, both as a backdrop and as a tool, to contemplate nearly invisible moments like conversion or the other life. In yet another centripetal shift, blackness invades the subject and makes its regard indistinct. A comparable indistinct turn in the treatment of light involves Shakespeare, who, in Romeo and Juliet, appropriates for the subject the function of reflection and contemplation. The subject emerges from darkness, like Narcissus and Medusa. Also thanks to the alchemical imagery of Antony and Cleopatra, and to the allusions to Medusa in Measure for Measure, Shakespeare turns indistinct blackness into the object of contemplation envisaged by Richard III and Macbeth.

Chapters 2 and 3 share a common centripetal direction: the translation of change into the subject, and the construction of darkness into a second light that helps contemplate the invisible. Chapter 4 ("The Indistinct Regard") is based not on the cross-analysis of a comparable element (the symbol in Chapter 2, and light and darkness in Chapter 3), but on how the human body is subject to indistinction by two unrelated forms: martyrdom in Caravaggio, and the sky and the sea in Shakespeare - two natural settings that barely capture Caravaggio's attention: he inserts a portion of the sky only in a corner of Sacrifice of Isaac (c. 1602), and the sea, so powerfully present in the last years of his vagabond life, is completely absent in his art. Chapter 4 shows two different forms of dispersal of the gaze. Caravaggio's larger religious paintings display the different manifestations of the divine in the human. The human (or divine) body occupies the centre, with a clear effect of dispersal of perspective. Shakespeare deploys this multiplied perspective by placing the human body of the subject in a world bereft of orientation, a triumph of indistinction enacted under the sky (Julius Caesar, King Lear, and Hamlet) or on the sea (The Winter's Tale, The Tempest). Death, and the other life, from means of devotional contemplation of the invisible turn 
into the indistinction whose acceptance enables the modern mind to see itself. The gaze turns downward into darkness, and the plunge into indistinction becomes a model of knowledge, an indistinct regard that refuses to "[p]artition make with spectacles so precious / 'Twixt fair and foul" (CYM 1.6.38-9); and yet this gaze lends new voice to imagination and "adds a precious seeing to the eye" (LLL 4.3.309).

\section{Notes}

1 Antony Ashley Cooper (the third Earl of Shaftesbury), Second Characters, or, the Language of Forms, ed. B. Rand (Cambridge: Cambridge University Press, 1914), p. 141. "Ut pictura poesis" is a quotation from Horace, Ars Poetica 361.

2 Michael Fried, The Moment of Caravaggio (Princeton, NJ-Oxford: Princeton University Press, 2010), Chapter 4, "Skepticism, Shakespeare, Address, Density", pp. 99-139.

3 See Lorenzo Pericolo, Caravaggio and Pictorial Narrative: Dislocating the 'Istoria' in Early Modern Painting (London: Harvey Miller Publishing, 2011); Alexander Nagel and Lorenzo Piccolo, "Unresolved Images: An Introduction to Aporia as an Analytical Category in the Interpretation of Early Modern Art”, in Subject as Aporia in Early Modern Art, ed. Alexander Nagel and Lorenzo Pericolo (Farnham: Ashgate, 2010), pp. 1-15.

4 Giovanna Sapori, "Stampe da Caravaggio e caravaggeschi", in Caravaggio e l'Europa: l'artista, la storia, la tecnica e la sua eredità (Cinisello Balsamo: SilvanaEditoriale, 2009), p. 163 (157-68).

5 Carel Van Mander, Het Schilder-Boeck (Haarlem: 1604), sig. 191 ${ }^{\mathrm{r}}$, qtd. in Howard Hibbard, Caravaggio (New York: Harper \& Row, 1983), p. 344. For recent biographies, see Andrew Graham-Dixon, Caravaggio: A Life Sacred and Profane (London: Allen Lane, 2010); Sybille Ebert-Schifferer, Caravaggio: The Artist and His Work (Los Angeles, CA: The Paul Getty Museum, 2012).

6 Giovanni Baglione, Le vite de' pittori, scultori et architetti: dal pontificio di Gregorio XIII del 1572 in fino a' tempi di papa Urbano Ottavo nel 1642 (Città del Vaticano: Biblioteca Apostolica Romana, 1995), I.139.

7 I am following the chronology proposed in John T. Spike, Caravaggio (New York-London: Abbeville Press Publishers, 2001), pp. 253-54.

8 See Spike, Caravaggio, p. 15; Claudio Strinati, L'immagine di San Francesco nella Controriforma (Rome: Edizioni Quasar, 1982), p. 92.

9 For a critique of the indeterminacy thesis proposed by W.V. Quine in Word and Object (1960) on the impossibility of correct translation, see John Searle, "Indeterminacy, Empiricism, and the First Person", The Journal of Philosophy, 84, 3(1987): 123-46, and Jerrold Katz, "The Refutation of Indeterminacy", The Journal of Philosophy, 85, 5(1988): 227-52.

10 For a recent discussion, see Eleanor Cook, "Ambiguity and the Poets", Connotations, 18, 1-3(2008/2009): 230-45, and Richard Chamberlain, "The Grimace of Ambiguity: Unambiguity and the Critics", Linguistics and Literature Studies, 3, 1(2015): 1-10.

11 Gerald Graff, "Determinacy/Indeterminacy", in Critical Terms for Literary Studies, ed. Frank Lentricchia and Thomas McLaughlin (Chicago, IL: University of Chicago Press, 1995), p. 172 (163-76). See also Timothi Bahti, "Ambiguity and Indeterminacy: The Juncture", Comparative Literature, 38 (1986): 209-23. 


\section{Imagine}

12 See Matthias Risse, “Arrow's Theorem, Indeterminacy, and Multiplicity Reconsidered", Ethics, 111, 4(2001): 706-34.

13 Jose V. Ciprut, "Introduction", in Indeterminacy: The Mapped, the Navigable, and the Uncharted, ed. Jose V. Ciprut (Cambridge, MALondon: The MIT Press, 2008), p. 2 (1-40).

14 Michael V. Fox, “The Uses of Indeterminacy”, Semeia, 71, 2(1995): 173-91, p. 175.

15 Aryeh Botwinick, "Interpretation and Indeterminacy", in Indeterminacy: The Mapped, the Navigable, and the Uncharted, ed. Jose V. Ciprut (Cambridge, MA and London: The MIT Press, 2008), p. 79 (79-100).

16 Bradford Skow, "Deep Metaphysical Indeterminacy”, The Philosophical Quarterly, 60, 241(2010): 852, p. 853 (851-58).

17 James D. Merriman, "The Parallel of the Arts: Some Misgivings and a Faint Affirmation", Journal of Aesthetics and Art Criticism, 31 (1972-1973): pp. 153-64, 309-21.

18 Caution against the extensive application of artistic tags and analogies could be already found in Rensselaer W. Lee, Ut Pictura Poesis: the Humanistic Theory of Painting (New York: W.W. Norton \& Company, 1967) - and M. Leslie, "The Dialogue Between Bodies and Souls: Picture and Poesy in the English Renaissance", Word \& Image, 1, 1(1985): 16-30.

19 See Jeroen Stumpel, "Speaking of Manner: Maniera and Its Meanings", in The Province of Painting: Theories of Italian Renaissance Art (Utrecht: private ed., 1990), pp. 97-128.

20 For instance, John Greenwood, Shifting Perspectives and the Stylish Style: Mannerism in Shakespeare and His Jacobean Contemporaries (Toronto, ON-Buffalo, NY-London: University of Toronto Press, 1988); Jean-Pierre Maquerlot, Shakespeare and the Mannerist Tradition: A Reading of Five Problem Plays (Cambridge: Cambridge University Press, 1995).

21 Ulrich Weisstein, "The Venial Sins of the Intermedialist or How to Avoid the Mutual Obfuscation of the Arts", in Metamorphosing Shakespeare: Mutual Illuminations of the Arts, ed. Patricia Kennan and Mariangela Tempera (Bologna: Clueb, 2004), p. 16, 17 (11-29).

22 Svetlana and Paul Alpers, "Ut Pictura Noesis? Criticism in Literary Studies and Art History", New Literary History, 3, 3(1972): 458.

23 Thomas McFarland, "Field, Constellation, and Aesthetic Object", New Literary History, 13, 3(1982): 439.

24 Leonard Barkan, "Living Sculptures': Ovid, Michelangelo, and The Winter's Tale", in Shakespeare and the Arts, pp. 146-47 (137-65).

25 Nicholas Ridley, The Works (Cambridge: Cambridge University Press, 1841), p. 94, qtd. in Clifford Davidson, "The Anti-Visual Prejudice", in Iconoclasm vs. Art and Drama, ed. Clifford Davidson and Ann Eljenholm Nichols (Kalamazoo, MI: Medieval Institute Publications, 1989), p. 41 (33-46).

26 William Perkins, Works (London: 1603), p. 841.

27 Brian Cummings, "Iconoclasm and Bibliophobia in the English Reformations, 1521-1558", in Images, Idolatry, and Iconoclasm in Late Medieval England: Textuality and the Visual Image, ed. Jeremy Dimmick, James Simpson, and Nicolette Zeeman (Oxford: Oxford University Press, 2002), pp. 185-206.

28 Injunction 23, in Tudor Royal Proclamations, ed. Paul L. Hughes and James F. Larkin (New Haven, CT: Yale University Press, 1964), II.123, sigg. $\mathrm{B} 3^{\mathrm{v}}-\mathrm{C} 2^{\mathrm{v}}$.

29 Margaret Aston, England's Iconoclasts (Oxford: Clarendon Press, 1988), p. 299. 
30 See Sergiusz Michalski, The Reformation and the Visual Arts: The Protestant Image Question in Western and Eastern Europe (London-New York: Routledge, 1993), pp. 169-96; Alexandra Walsham, "Idols in the Frontispiece? Illustrating Religious Books in the Age of Iconoclasm", in Illustrated Religious Texts in the North of Europe, 1500-1800, ed. Feike Dietz et al. (Farnham: Ashgate, 2014).

31 Jean Calvin, Institutes of the Christian Religion, ed. and trans. Henry Beveridge (Edinburgh: The Calvin Translation Society, 1845), I.xi.7, 12, pp. 97, 100-101.

32 Certaine Sermons or Homilies Appointed to be Read in Churches (London: 1623), p. 44, 27.

33 Dana Bentley-Cranch, The Renaissance Portrait in France and England (Paris: Honoré Champion, 2004), p. 179.

34 See The Authority of the Word. Reflecting on Image and Text in Northern Europe, 1400-1700, ed. Celeste Brusati, Karl A. E. Enenkel, and Walter S. Melion (Leiden-Boston: Brill, 2012); Richard Viladesau, "The Protestant Reformation in the Church and the Arts", in The Triumph of the Cross. The Passion of Christ in Theology and the Arts, from the Renaissance to the Counter-Reformation (Oxford: Oxford University Press, 2008), pp. 103-81; Kathleen Kamerick, "Staying the Senses: Image and Word in Prayer Books", in Popular Piety and Art in the Late Middle Ages. Image Worship and Idolatry in England 1300-1500 (New York: Palgrave, 2002), pp. 155-90.

35 Timothy J. Gorringe, Earthly Visions: Theology and the Challenges of Art (New Haven, CT-London: Yale University Press, 2011), p. 113.

36 Thomas Cranmer, The Miscellaneous Writings and Letters, ed. John E. Cox (Cambridge: Cambridge University Press, 1846), II.101, qtd. in John Phillips, The Reformation of Images: Destruction of Art in England, 1535-1660 (Berkeley-Los Angeles-London: University of California Press, 1973), p. 57.

37 Johannes Molanus, De Picturis et Imaginibus Sacris (Louvain: 1570), fol. 81v .

38 The Dialogue Concerning Tyndale, ed. W.E. Campbell and A.W. Reed (London: Eyre and Spottiswoode, 1927), p. 20, qtd. in Phillips, The Reformation of Images, p. 44.

39 Roy Strong, The Tudor and Stuart Monarchy: Pageantry, Painting, Iconography, 3 vols. (Woodbridge: The Boydell Press, 1995), 1.16-17.

40 Kim Sloan, "Learning to Limn", in 'A Noble Art': Amateur Artists and Drawing Masters c.1600-1800 (London: British Museum Press, 2000), pp. 40-77.

41 See A. Riehl, The Face of Queenship: Early Modern Representations of Elizabeth I (New York: Palgrave Macmillan, 2010).

42 William Thomas, History of Italy (London: 1549), fol. $34^{\mathrm{v}}, 37^{\mathrm{r}}$.

43 The Poems of Henry Constable, ed. Joan Grundy (Liverpool: Liverpool University Press, 1960), p. 35.

44 Roy Strong, The English Renaissance Miniature (London: Thames and Hudson, 1983), p. 159, 175.

45 John Peacock, "Inigo Jones as a Figurative Artist", in Renaissance Bodies: The Human Figure in English Culture c.1540-1660, ed. Lucy Gent and Nigel Llewellyn (London: Reaktion Books, 1990), p. 165 (154-79).

46 Susan Foister, "Sixteenth-Century English Portraiture and the Idea of the Classical", in Albion's Classicism: The Visual Arts in Britain, 1550-1660, ed. Lucy Gent (New Haven, CT-London: The Yale University Press, 1995), pp. 169-71 (163-80).

47 Lucy Gent, Picture and Poetry 1560-1620: Relations Between Literature and the Visual Arts in the English Renaissance (Leamington Spa: James 


\section{Imagine}

Hall, 1981), p. 6. See also Joseph Monteyne, The Printed Image in Early Modern London: Urban Space, Visual Representation, and Social Exchange (Aldershot: Ashgate, 2007).

48 Mary E. Hazard, Elizabethan Silent Language (Lincoln, NE-London: University of Nebraska Press, 2000), pp. 23-45.

49 Anthony Wells-Cole, Art and Decoration in Elizabethan and Jacobean England: The Influence of Continental Prints, 1558-1625 (New Haven, CT-London: Yale University Press, 1997), pp. 15-32.

50 Edward Norgate, Miniatura or the Art of Limning, ed. Martin Hardie (Oxford: Oxford University Press, 1918), p. 39.

51 Roy Strong, The English Renaissance Miniature, p. 9. See Raphaëlle Costa de Beauregard, Nicholas Hilliard et l'imaginaire elisabethain 15471619 (Paris: Editions du Centre National de la Recherche Scientifique, 1991).

52 John Peacock, "The Politics of Portraiture", in Culture and Politics in Early Stuart England (London: Macmillan, 1994), p. 209 (199-228); Roy Strong, The English Icon: Elizabethan \& Jacobean Portraiture (London: Routledge \& Kegan Paul - New York: Pantheon Books, 1969), pp. 13-21.

53 Pliny, The History of the World, trans. Philemon Holland (London: 1601), p. 522.

54 Nicolas Hilliard, "A Treatise Concerning the Arte of Limning”, in A Treatise Concerning the Arte of Limning, together with A More Compendious Discourse Concerning Ye Art of Limning by Edward Norgate, ed. Robert Kelsey Rought Thornton and Thomas Grant Steven Cain (Ashington: Mid Northumberlands Arts Group, 1981), p. 75.

55 “An inventory of my books 1594, Feb. 14", Oxford, Bodleian Library, MS Rawlinson D. 213, fol. $6^{\mathrm{r}}$, qtd. in Gent, Picture and Poetry 1560-1620, p. 3.

56 See Tatiana C. String, Art and Communication in the Reign of Henry VIII (Aldershot: Ashgate, 2008); Strong, The Tudor and Stuart Monarchy, I.1-53, 2.1-7; Neil Cuddy, "Dynasty and Display: Politics and Painting in England, 1530-1630", in Dynasties: Painting in Tudor and Jacobean England 1530-1630, ed. Karen Hearn (London: Tate Publishing, 1995), pp. 11-20.

57 Fairchild, Shakespeare and the Arts of Design (Architecture, Sculpture, and Painting), pp. 107-109.

58 See Erin C. Blake, "Shakespeare, Portraiture, Painting and Prints", in The Edinburgh Companion to Shakespeare and the Arts, ed. Mark Thornton Burnett, Adrian Streete and Ramona Wray (Edinburgh: Edinburgh University Press, 2011), pp. 409-34.

59 Keith Thomas, "English Protestantism and Classical Art", in Albion's Classicism: The Visual Arts in Britain, 1550-1660, ed. Lucy Gent (New Haven, CT-London: The Yale University Press, 1995), pp. 226-27 (221-38).

60 Foister, "Sixteenth-Century English Portraiture", p. 163.

61 William Gaunt, Court Painting in England from Tudor to Victorian Times (London: Constable, 1980), p. 32.

62 See Margaret Aston, The King's Bedpost: Reformation and Iconography in a Tudor Group Portrait (Cambridge: Cambridge University Press, 1993); Strong, The Tudor and Stuart Monarchy, 1.88-92.

63 Gaunt, Court Painting in England, pp. 37-51.

64 On the importance of moral as well as factual veracity, see Robert Tittler, "Portraiture and Memory Amongst the Middling Elites in Post-Reformation England", in The Arts of Remembrance in Early Modern England. Memorial Cultures of the Post Reformation (Farnham: Ashgate, 2013), pp. 37-57.

65 Strong, The English Icon, p. 14. 
66 Strong, Tudor and Stuart Monarchy, 2.165-67.

67 Murray J. Lewith, "Coriolanus and the Flaying of Marsyas", in Shakespeare and the Visual Arts, ed. Holger Klein and James L. Harner (Lewiston, NY-Queenston, ON-Lampeter: The Mellen Press, 2000), pp. 444-46 (442-53).

68 See Keir Elam, Shakespeare's Pictures. Visual Culture in Drama (London: The Arden Shakespeare, Bloomsbury, 2017).

69 Erwin Panofsky, Problems in Titian: Mostly Iconographic (New York: New York University Press, 1969), p. 153. See also John Doebler, "The Reluctant Adonis: Titian and Shakespeare", Shakespeare Quarterly, 33, 4(1982): 480-90. It is, however, debatable whether these unsubstantiated occurrences might have superseded the literary source, Ovid - see Georgianna Ziegler, "Picturing Venus and Adonis: Shakespeare and the Artists", in Venus and Adonis: Critical Essays, ed. Philip C. Kolin (New York-London: Garland Publishing, 1997), pp. 389-403.

70 See John Buxton, Elizabethan Taste (London: Macmillan, 1963), pp. 95, 97, 101-103.

71 Paolo Giovanni Lomazzo, A Tracte Containing the Artes of Curious Paintinge (1598) (Amsterdam-New York: Da Capo Press, 1969), "To the Ingenuous Reader", sig. $\mathrm{v}^{\mathrm{v}}$.

72 See Stephen Orgel, "Idols of the Gallery: Becoming a Connoisseur in Renaissance England", in Early Modern Visual Culture: Representation, Race, and Empire in Renaissance England, ed. Peter Erickson and Clark Hulse (Philadelphia: University of Pennsylvania Press, 2000), pp. 251-52 (251-83).

73 Henry Peacham, The Compleat Gentleman [1634] (rpt. Oxford: Clarendon Press, 1906), p. 107. Lord Lumley's collection, in part later donated to Arundel, included de Vriendt's Mary Magdalene and Noah, a Nativity, a St Jerome, a Conversion of St Paul.

74 Maurice Howard, "The Treatise and Its Alternatives: Theory and Pratice in Sixteenth-Century England", in Théorie des arts et création artistique dans l'Europe $d u$ Nord du XVI au début du XVIII siècle, éd. MichèleCaroline Heck, Frédérique Lemerle et Yves Pauwels (Lille: Collection UL3 Travaux et recherches, 2002), pp. 141-53.

75 See John L. Lievsay, The Englishman's Italian Books: 1550-1700 (Philadelphia: University of Pennsylvania Press, 1969); Frederick O. Waage, "'Be Stone No More': Italian Cinquecento Art and Shakespeare's Last Plays", Bucknell Review, 25, 1(1980): 56-87. Henry Peacham was aware of the existence of two copies of Vasari in England, one of whom owned by Inigo Jones, but did not have the chance to read it. Jones' manuscript annotations on Vasari's 1568 edition of the Vite dated to c. 1610 - Three Volumes Annotated by Inigo Jones: Vasari's 'Lives' (1568), Plutarch's 'Moralia' (1614), Plato’s 'Republic' (1554), ed. Anthony W. Johnson (Åbo: Åbo Akademi University Printing Press, 1997), pp. 5-6.

76 Lindsay Stainton and Christopher White, Drawing in England from Hilliard to Hogarth (London: British Museum Publications, 1987), p. 13, 16.

77 Ruth Webb, "Ekphrasis Ancient and Modern: The Invention of a Genre”, Word \& Image, 15, 1(1999): 14 (7-18). See also Andrew Sprague Becker, The Shield of Achilles and the Poetics of Ekphrasis (Lanham, MD: Rowman \& Littlefield, 1995).

78 See Murray Krieger, Ekphrasis: The Illusion of the Natural Sign (Baltimore, MD-London: The Johns Hopkins University Press, 1992). 
79 Gian Giorgio Trissino, La poetica (V-VI), in Trattati di poetica e retorica del Cinquecento, ed. Bernard Weinberg (Bari: Laterza, 1970-74), 4 vols, II.76. Cfr. Aristotle, Rhetorics XI.3, 1411b-1413 ${ }^{\mathrm{a}}$; Quintilian, Institutio oratoria, VIII.3.61-62; Rhetorica ad Herennium IV.34.45.

80 Lorna Hutson, "Law, Probability and Character in Shakespeare", in Fictions of Knowledge. Fact, Evidence, Doubt, ed. Yota Batsaki, Subha Mukherji, and Jan-Melissa Schramm (New York: Palgrave Macmillan, 2012), p. 65 (61-83). See also Heinrich F. Plett, Enargeia in Classical Antiquity and the Early Modern Age: The Aesthetics of Evidence (Leiden: Brill, 2012).

81 See Claire Lapraik Guest, "On Energeia", in Imitation, Representation and Priting in the Italian Renaissance, ed. Roy Eriksen and Magne Malmanger (Pisa-Rome: Fabrizio Serra Editore, 2009), p. 83 (83-100).

82 George Chapman, Preface to Ovids Banquet of Sence (1595), in The Poems of George Chapman, ed. Phyllis Brooks Bartlett (New York-London: Oxford University Press, 1941), p. 49.

83 See David Evett, Literature and the Visual Arts in Tudor England (Athens-London: The University of Georgia Press, 1990), p. 45; Mary E. Hazard, “An Essay to Amplify 'Ornament': Some Renaissance Theory and Practice”, Studies in English Literature, 1500-1900, 16(1976): 15-32.

84 From George Chapman's preface to his 1598 translation of the Iliad, in Elizabethan Critical Essays, ed. G. Gregory Smith (London: Geoffrey Cumberlege, 1950), II.298.

85 John Hoskins, Directions for Speech and Style, 1599, ed. Hoyt H. Hudson (Princeton, NJ: Princeton University Press, 1935), p. 17.

86 W.J.T. Mitchell, Picture Theory. Essay on Verbal and Visual Representation (Chicago, IL: The University of Chicago Press, 1994), pp. 66-67.

87 See the recent Shakespeare and the Visual Arts. The Italian Influence, ed. Michele Marrapodi (Abingdon-New York: Routledge, 2017).

88 Lionardo Salviati, "Oratione IV in lode della pittura, fatta nell'occasione della morte di Michelangelo Buonarroti l'anno 1564", in Opere del cavaliere Lionardo Salviati (Milan, Società tipografica de' Classici italiani, 1810), vol. 4, p. 92, 100.

89 The Rape of Lucrece probably rested on the pictorial tradition depicting the heroine (half) nude and holding the dagger in a direct address to the beholder David Rosand, “'Troyes Painted Woes': Shakespeare and the Pictorial Imagination", in Shakespeare and the Arts, ed. Stephen Orgel and Sean Keilen (New York-London: Garland Publishing, 1999), p. 238 (215-43).

90 Ernst H. Gombrich, "Icones Symbolicae: Philosophies of Symbolism and Their Bearing on Art", in Symbolic Images: Studies in the Art of the Renaissance (London: Phaidon, 1972), p. 147 (123-95).

91 See Keith Moxey, "Visual Studies and the Iconic Turn", in Visual Time. The Image in History (Durham, NC-London: Duke University Press, 2013), pp. 54ff (53-75).

92 Quintilian, Institutio VI.2.20-36; Cicero, De inventione I.55.107. See Peter Mack, "Early Modern Ideas of Imagination. The Rhetorical Tradition", in Imagination in the Later Middle Ages and Early Modern Times, ed. Lodi Nauta and Detlev Pätzold (Leuven-Paris-Dudley, MA: Peeters, 2004), pp. 59, 61-62 (59-76).

93 Stephen Bat[e]man, Batman vppon Bartholome, His Booke De Proprietatibus Rerum (London: 1582), Book 2, Chapter 3, "Of the Braine".

94 Avicenna, De anima, in Opera (Venice: 1508), I.v, p. $5^{\text {r }}$, col. B, D.

95 Marsilio Ficino, Sopra lo amore, ovvero il convito di Platone, ed. Giuseppe Rensi (Lanciano: Casa Editrice Rocco Carabba, 1934), Or. I, cap. 2, p. 19. 
96 Bernard McGinn, "Visio dei. Seeing God in Medieval Theology and Mysticism", in Envisaging Heaven in the Middle Ages, ed. Carolyn Muessig and Ad Putter (London-New York: Routledge, 2007), pp. 15-33.

97 From the twelfth-century pseudo-Augustinian treatise De spiritu et anima, Migne, Patrologia Latina, 40:797 (cfr. Augustine, De genesi ad litteram I.11-16). See Walter S. Melion, "Meditative Images and the Portrayal of Image-Based Meditation", in Ut Pictura Meditatio. The Meditative Image in Northern Art, 1500-1700, ed. Walter S. Melion, Ralph Dekoninck and Agnes Guiderdoni-Bruslé (Turnhout: Brepols, 2012), pp. 1-60.

98 John S. Hendrix, "Perception as a Function of Desire in the Renaissance", in Renaissance Theories of Vision, ed. John S. Hendrix and Charles H. Carman (Aldershot: Ashgate, 2010), p. 89 (89-102).

99 See Thijs Weststeijn, "Seeing and the Transfer of Spirits in Early Modern Art Theory", in Renaissance Theories of Vision, ed. John S. Hendrix and Charles H. Carman (Aldershot: Ashgate, 2010), pp. 151-52, 159 (149-69).

100 Aristotle, The problemes of Aristotle with other philosophers and phisitions. Watin are contayned diuers questions, with their answers, touching the estate of mans bodie (Edinburgh: 1595), sigg. L7 ${ }^{\mathrm{r}}-\mathrm{L} 7^{\mathrm{v}}$, qtd. in James A. Knapp, Image Ethics in Shakespeare and Spenser (New York: Palgrave Macmillan, 2011), p. 5.

101 See Judith Dundas, “Artificial Strife': Shakespeare and Emulation”, in Pencils Rhetorique: Renaissance Poets and the Art of Painting (Newark: University of Delaware Press - London-Toronto: Associated University Presses, 1993), pp. 54-89.

102 Paolo Giovio, Ragionamento di mons. Paolo Giovio sopra $i$ motti e $i$ disegni d'arme, e d'amore, che communemente chiamano Imprese (Venice: 1556), p. 122.

103 Anne Friedberg, The Virtual Window: From Alberti to Windows (Cambridge, MA-London: The MIT Press, 2006), p. 5, 28. Alberti's rendering of the visible world as the projection onto the eye of a flat surface, thus a painting or a window, tricked the viewer into accepting as veracious the "virtual reproduction of a virtual image" - A. Mark Smith, From Sight to Light: The Passage from Ancient to Modern Optics (Chicago: University of Chicago Press, 2015), pp. 315-16. Mitchell noted the progressive sublimation of the image until the "tyranny" of the picture in Alberti and in artificial perspective - W.J.T. Mitchell, Iconology. Image, Text, Ideology (Chicago-London: The University of Chicago Press, 1986), p. 37.

104 Klaus Krüger, "Authenticity and Fiction: On the Pictorial Construction of Inner Presence in Early Modern Italy", in Image and Imagination of the Religious Self in Late Medieval and Early Modern Europe, ed. Reindert Falkenburg, Walter S. Melion and Todd M. Richardson (Turnhout: Brepols, 2007), pp. 37-69.

105 George Puttenham, The Art of English Poesie, ed. Frank Whigham and Wayne A. Rebhorn (Ithaca, NY-London: Cornell University Press, 2007), III.19, p. 329.

106 Samuel Daniel, Musophilus, 11. 178-80, qtd. in Mary E. Hazard, "The Anatomy of 'Liveliness' as a Concept in Renaissance Aesthetics", The Journal of Aesthetics and Art Criticism, 33, 4(1975): 414 (407-18).

107 See Joseph Hurt, "Les arts rivaux", Neophilologus, 72(1988): 168-79; Gerard LeCoat, The Rhetoric of the Arts, 1550-1650 (Bern: Herbert Lang, Frankfurt/M.: Peter Lang, 1975).

108 Ben Jonson, "Discoveries", in The Cambridge Edition of the Works of Ben Jonson, ed. Lorna Hutson (Cambridge: Cambridge University Press, 2012), vol. 7, p. 550. The passage loosely follows Antonio Possevino's Bibliotheca selecta, quae agitur de ratione studiorum (Rome: 1593). 


\section{Imagine}

109 G.B. Armenini, De' veri precetti della pittura (Ravenna: 1586), in Scritti d'arte del Cinquecento, ed. Paola Barocchi (Milan-Naples: Ricciardi, 1971-7), 3 vols, 1.264.

110 Philip Sidney, An Apology for Poetry, or The Defense of Poesy, ed. G. Shepherd (Manchester: Manchester University Press, 1980), p. 101.

111 Lodovico Dolce, Dialogo della pittura intitolato l'Aretino (www.memofonte. it/home/files/pdf/scritti_dolce.pdf, last accessed: June 15th, 2017), p. 6.

112 Renssselaer, Ut Pictura Poesis, p. 3. On the spur of Cicero (De oratore II.44), Alberti presents painting as persuasive representation, where compositio is introduced as a major virtue of style and the elements of storia, gravitas and enargeia combine to emotionally involve the spectator. See Caroline Van Eck, Classical Rhetoric and the Visual Arts in Early Modern Europe (Cambridge: Cambridge University Press, 2007).

113 Benedetto Varchi, Lezzione nella quale si disputa della maggioranza delle arti e qual sia più nobile, la scultura o la pittura (Florence: 1556), p. 55.

114 Michael Baxandall, Giotto and the Orators. Humanist Observers of Painting in Italy and the Discovery of Pictorial Composition (Oxford: Clarendon Press, 1971; rpt. 2006), p. 17.

115 See Olivia Rosenthal, Donner à voir: écritures de l'image dans l'art de poésie an XVI siècle (Paris: Honoré Champion Éditeur, 1998), p. 103.

116 See Frank Zöllner, "The 'Motions of the Mind' in Renaissance Portraits: The Spiritual Dimension of Portraiture", Zeitschrift für Kunstgeschichte, 68, 1(2005): 23-24 (23-40).

117 Thomas Heywood, An Apology for Actors (1612) (New York: Garland, 1973), sigg. $\mathrm{B} 3^{\mathrm{v}}-\mathrm{B} 4^{\mathrm{r}}$.

118 Michael Baxandall, Painting and Experience in Fifteenth-Century Italy: A Primer in the Social History of Pictorial Style (Oxford: Oxford University Press, 1991), pp. 29-108.

119 Olivier Darrigol, A History of Optics: From Greek Antiquity to the Nineteenth Century (Oxford: Oxford University Press, 2012), pp. 29-30.

120 Anne-Élisabeth Spica, "Rhétorique et herméneutique du discours sacré dans la literature en images de l'âge baroque: quelques pistes de recherché", in Emblemata Sacra. Rhétorique et herméneutique du discours sacré dans la literature en images, éd. R. Denkoninck et A. Guiderdoni-Bruslé (Turnhout: Brepols, 2007), p. 21 (19-38).

121 Knapp, Image Ethics, p. 2.

122 Richard Brathwaite, Essaies upon the five senses (London: 1620), pp. 3-4, qtd. in Knapp, Image Ethics, p. 3.

123 William Prynne, Histrio-mastix, The Player's Scourge; or Actors Tragedie (London: 1633), pt. 2, p. 94.

124 Johannes Sturm, Nobilitas Literata: liber unus (Rihel: 1549), fol. $45^{\mathrm{v}}-46^{\mathrm{r}}$.

125 Karsten Harries, Infinity and Perspective (Cambridge, MA: MIT Press, 2001), p. 34.

126 Alexander Nagel, The Controversy of Renaissance Art (Chicago-London: University of Chicago Press, 2011), p. 41.

127 Marcus Nordlund, The Dark Lantern: A Historical Study of Sight in Shakespeare, Webster, and Middleton (Goteborg: Acta Universitatis Gothoburgensis, 1999), p. viii.

128 M. Camille, "Before the Gaze: the Internal Senses and Late Medieval Practices of Seeing", in Visuality Before and Beyond the Renaissance: Seeing as Others Saw, ed. Robert S. Nelson (Cambridge: Cambridge University Press, 2000), pp. 197-223. See also Martin Jay, "Scopic Regimes of Modernity", in Vision \& Visuality, ed. Hal Foster (Seattle, WA: Bay Press, 1988), pp. 3-23. 
129 Olivier Boulnois, "Ego ou Cogito? Doute, tromperie divine et certitude de soi, du XIV $\mathrm{XI}^{\mathrm{e}}$ aVI $\mathrm{X}^{\mathrm{e}}$ siècles", in Généalogies du sujet: de saint Anselme à Malebranche, éd. Olivier Boulnois (Paris: Vrin, 2007), pp. 171-213. On the constitution of the self in the subject resisting divine will, see Dispositifs du sujet à la Renaissance, éd. M. Narcy et G. Sfez (Paris: PUF, 2000).

130 Augustine, Enarrationes in Psalmos (Patrologia Latina XXXVI, col. 186; Ps 24.20). See Stéphan Geonget, La notion de perplexité à la Renaissance (Genève: Droz, 2006), pp. 174-75.

131 Richard Huloet, Huloets Dictionarie Newelye Corrected, Amended, Set in Order and Enlarged [...] By Iohn Higgins (London: 1572), s.v. "Indifferencie".

132 See B. Gibbons, Shakespeare and Multiplicity (Cambridge: Cambridge University Press, 1993).

133 Bertrand Russell, "Vagueness" (1923), in Vagueness. A Reader, ed. Rosanna Keffe and Peter Smith (Cambridge, MA-London: The MIT Press, 1996), p. 61 (61-68). See also Ruth Garren Millikan, "On Clear and Indistinct Ideas", Philosophical Perspectives, 8(1994): 75-100.

134 Ben Crystal and David Crystal, Shakespeare's Words: A Glossary and Language Companion, Penguin (www.shakespeareswords.com; last accessed: June 15 2017).

135 Samuel Harsnett, A Declaration of Egregious Popish Impostures (London: 1603), p. 159.

136 Plutarch, The Philosophie, Commonlie Called, the Morals, trans. P. Holland (London: 1603), p. 1049, 1031, 1341.

137 Guglielmo Gratarolo, The Castel of Memorie, Wherein is Conteyned the Restoring, Augmenting, and Conseruing of the Memorye and Remembraunce, trans. William Fulwod (London: 1562), sig. Fvii ${ }^{\mathrm{r}}$.

138 Giacomo Affinati d'Acuto, The Dumbe Dinine Speaker, or: Dumbe Speaker of Diuinity, trans. Anthony Munday (London: 1605), p. 265.

139 Norman Kretzmann, "Goodness, Knowledge, and Indeterminacy in the Philosophy of Thomas Aquinas”, The Journal of Philosophy, 80, 10 (1983): 641, commenting on Aquinas, Summa Contra Gentiles, I.65.1.

140 Jean E. Feerick and Vin Nardizzi, The Indistinct Human in Renaissance Literature (New York: Palgrave MacMillan, 2012).

141 Thomas Bell, The Survey of Popery (London: 1596), p. 181.

142 Puttenham, Arte of English Poesie, I.8, p. 109.

143 Torquato Tasso, Discourses on the Heroic Poem (Discorsi del poema eroico), trans. Mariella Cavalchini and Irene Samuel (Oxford: Clarendon Press, 1973), p. 78, 67.

144 Edmund Husserl, Ideas Pertaining to a Pure Phenomenology and to a Phenomenological Philosophy, trans. F. Kersten (Dordrecht: Kluwer Academic Publishers, 1982), p. 92.

145 Giorgio Agamben, State of Exception, trans. Kevin Kittel (LondonChicago: University of Chicago Press, 2007), pp. 23ff.

146 Georges Poulet, La pensée indéterminée. I, De la Renaissance au romantisme (Paris: Presses Universitaires de France, 1985), p. 43.

147 John Davies, "Nosce Te Ipsum", in The Complete Poems of Sir John Davies, ed. Alexander B. Grosart (London: Chatto \& Windus, 1876), I.24.

148 Alain de Libera, L'invention du sujet moderne. Cours du Collège de France 2013-2014 (Paris: Librarie Philosophique J. Vrin, 2015), pp. 21-22. Schmutz notes that Descartes referred to "le moi" and then identified it with the soul, while Kant was the first one to place the cogito as the subject of knowledge Jacob Schmutz, "L'existence de l'Ego comme premier principe métaphysique avant Descartes”, in Généalogies du sujet, pp. 215-68. 


\section{Imagine}

149 Peter Burke, "Representations of the Self from Petrarch to Descartes", in Rewriting the Self. Histories from the Renaissance to the Present, ed. Roy Porter (London-New York: Routledge, 1997), p. 19 (17-28). For the discussion of the boundaries between public persona and private self, see Geoff Baldwin, "Individual and Self in the Late Renaissance", The Historical Journal, 44, 2(2001): 341-64; Terry G. Sherwood, The Self in Early Modern Literature: For the Common Good (Pittsburgh, PA: Duquesne University Press, 2007), and Debora Shuger, Habits of Thought in the English Renaissance: Religion, Politics, and the Dominant Culture (Toronto: University of Toronto Press, 1997), p. 257. See also Subject and Object in Renaissance Culture, ed. Margreta de Grazia, Maureen Quilligan, and Peter Stallybrass (Cambridge: Cambridge University Press, 1996), and John Jeffries Martin, Myths of Renaissance Individualism (Houndmills: Palgrave Macmillan, 2004). 


\section{Bibliography}

\section{Primary Works}

Affinati d'Acuto, Giacomo, The Dumbe Dinine Speaker, Or: Dumbe Speaker of Diuinity, transl. Anthony Munday (London: 1605).

Aglionby, William, Painting Illustrated in Three Diallogues (London: 1686).

Agrippa, Cornelius, Occult Philosophy, transl. J.F. (London: 1651).

Alberti, Leon Battista, On Painting, transl. John R. Spencer (New Haven and London: Yale University Press, 1966 [1956]).

Alciato, Andrea, Andreae Alciati Emblemata cum Commentariis Claudii Minois (Padua: 1621).

Aquinas, Thomas, Quaestiones quodlibetales, éd. P. Mandonnet (Paris: Lethielleux, 1926).

-, Sancti Thomae de Aquino Summa Theologiae. Textum Leoninum Romae 1889 editum (www.corpusthomisticum.org/sth1065.html, last accessed June 14, 2017).

Aristotle, The problemes of Aristotle with other philosophers and phisitions. Wherein are contayned diuers questions, with their answers, touching the estate of mans bodie (Edinburgh: 1595).

$\longrightarrow$, Aristotle on Rhetoric. A Theory of Civic Discourse, transl. G.A. Kennedy (New York and Oxford: Oxford University Press, 1991).

St. Augustine, Of the citie of God vvith the Learned Comments of Io. Lod. Viues, Englished by I.H. [John Healey] (London: 1610).

Averell, William, A Meruailous Combat of Contrarieties Malignantly Striuing in the Me[m]bers of Mans Bodie ... (London, 1588).

Avicenna, Opera (Venice: 1508).

Bacon, Francis, The Works of Sir Francis Bacon, ed. James Spedding, Robert Ellis, and Douglas Heath, 14 vols (London: Longman's, 1868-90).

- Francis Bacon: A Selection of His Works, ed. Sidney Warhaft (Toronto and London: Macmillan, 1965).

Bacon, Roger, "A Briefe Commentarie of Hortulanus the Philosopher, upon the Smaragdine Table of Hermes of Alchimy", in The Mirror of Alchimy, Composed by the Thrice-Famous and Learned Fryer, Roger Bachon (London: 1579).

Baglione, Giovanni, Le vite de' pittori, scultori et architetti: dal pontificio di Gregorio XIII del 1572 in fino a' tempi di papa Urbano Ottavo nel 1642, 3 vols (Città del Vaticano: Biblioteca Apostolica Romana, 1995).

Barrough, Philip, The Method of Phisick (London: 1583). 


\section{Bibliography}

Bate, John, The Mysteries of Nature and Art (London: 1634).

Batman, Stephen, The Golden Booke of the Leaden Goddes Wherein is Described the Vayne Imaginations of Heathe[n] Pagans, and Counterfaict Christians (London: 1577).

- Batman vppon Bartholome, His Booke De Proprietatibus Rerum (London: 1582).

Bell, Thomas, The Survey of Popery (London: 1596).

Bellori, Giovanni Pietro, Le vite de' pittori, scultori e architetti moderni, ed. E. Borea (Turin: Einaudi, 1976).

The Holy Bible Quatercentenary Edition. An Exact Reprint in Roman Type, Page for page, Line for Line, and Letter for Letter of the King James Version (Oxford and New York: Oxford University Press, 2010).

Boccaccio, Giovanni, “Genealogia Deorum Gentilium”, in Tutte le opere di Giovanni Boccaccio, ed. Vittore Branca, vols. VII and VIII (Milan: Mondadori, 1998).

Bocchi, Achille, Les Questions symboliques d'Achille Bocchi. Symbolicae Quaestiones, 1555. Tome 1, Introduction et edition critique du texte latin; Tome 2, Traduction, annotation et commentaire, éd. Anne Rolet, Tours, Presses Universitaires François-Rabelais de Tours (Rennes: Presses universitaires de Rennes, 2015).

Bonifaccio, Giovanni, L'arte de' Cenni (Vicenza: 1616).

The Book of Common Prayer, in Its History and Interpretation, ed. R.P. Blakeney (London: James Miller, 1865).

Borromeo, Federigo, De Pictura Sacra (1624) (Sora: Camastro, 1932).

Bruno, Giordano, Le ombre delle idee (De umbris idearum), ed. N. Tirinnanzi (Milan: Rizzoli, 2008).

- "De imaginum, signorum \& idearum compositione, 1591", in Opere mnemotechniche, ed. M. Matteoli, R. Sturlese, and N. Tirinnanzi (Milan: Adelphi, 2009).

- Opere italiane, ed. Giovanni Aquilecchia, 2 vols (Turin: UTET, 2013).

Burton, Robert, The Anatomy of Melancholy. The Sixth Edition, corrected and augmented by the Author (Oxford: 1651).

Calvin, Jean, Institutes of the Christian Religion, ed. and transl. H. Beveridge, 2 vols (Edinburgh: The Calvin Translation Society, 1845).

Cartari, Vincenzo, Imagini delli Dei de gl'Antichi, facsimile ed. 1647 (Milan: Luni Editrice, 2004).

Castiglione, Baldesar, The Courtyer of Count Baldessar Castilio Diuided into Foure Bookes, transl. Thomas Hoby (London: 1561).

Castelvetro, Lodovico, Poetica d'Aristotele vulgarizzata, et sposta (Wien: 1570).

Cennino Cennini, Libro dell'arte, ed. Carlo Milanesi (Florence: LeMonnier, 1859).

Chapman, George, The Poems of George Chapman, ed. Phyllis Brooks Bartlett (New York and London: Oxford University Press, 1941).

Constable, Henry, The Poems of Henry Constable, ed. Joan Grundy (Liverpool: Liverpool University Press, 1960).

Conti, Natale, Mythologiae sive explicationes fabularum libri X (Venice: 1568).

Cuningham, W., The Cosmographical Glasse. Counteyning the Pleasant principle of Cosmographie, geographie, Hydrographie, or Navigation (London: 1559).

Daniel, Samuel, Poems and a Defence of Ryme, ed. Arthur Colby Sprague [1930] rpt. (Chicago: Chicago University Press, 1965). 
Davies, John, The Complete Poems of Sir John Davies, ed. Alexander B. Grosart, 2 vols (London: Chatto \& Windus, 1876).

Davies of Hereford, John, Mirum in Modum (London: 1602).

De la Primaudaye, Pierre, The Second Part of the French Academie (London: 1605).

Digges, Leonard, A Prognostication Everlasting (London: 1576).

Dolce, Lodovico, Dialogo della pittura intitolato l'Aretino (http://www. memofonte.it/home/files/pdf/scritti_dolce.pdf, last accessed June 15, 2017).

Donne, John, Devotions upon Emergent Occasions, ed. John Sparrow (Cambridge: Cambridge University Press, 1923).

- The Sermons of John Donne, 10 vols, ed. George R. Potter and Evelyn M. Simpson (Berkeley and Los Angeles: University of California Press, 1953-62).

Drexelius, Ieremie, The Christians Zodiake or Twelue Signes of Predestination into Life Euerlasting (London: 1643).

Du Chesne, Joseph, The Practice of Chymicall, and Hermetical Physicke, for the Preseruation of Health. Written in Latin by Josephus Quersitanus, Doctor of Phisicke. And translated into English, by Thomas Timme, minister (London: 1605).

Elizabethan Critical Essays, ed. G. Gregory Smith (London: Geoffrey Cumberlege, 1950).

Erasmus, Desiderius, Adagia quaecumque ad hanc diem exierunt (Florence: 1575).

Fabularum Ovidii Interpretatio, Ethica, Physica, et Historica, tradita in Academia Regiomontana à Georgio Sabino (Cambridge: 1589).

Ferrier, Oger, A Learned Astronomical Discourse of the Ivdgement of Nativities, transl. Thomas Kelway (London: 1642).

Ficino, Marsilio, De vita libri tres (Basel: 1529).

- Sopra lo amore o ver Convito di Platone, ed. Giuseppe Rensi (Lanciano: Carabba, 1934).

Flamel, Nicholas, Nicholas Flammel, his Exposition of the hieroglyphicall figures which he caused to bee painted vpon an arch in St. Innocents Churchyard, in Paris. Together with the secret booke of Artephius, and the epistle of John Pontanus ... by Eirenaeus Orandus (London: 1624).

Fortescue, Thomas, The Foreste or Collection of histories no lesse profitable, then pleasant and necessarie, doone out of Frenche into Englishe, translation of Pedro Mexia's Silva de varia lección (London: 1571).

Foxe, John, The Acts and Monuments (London: 1563).

Fraunce, Abraham, The Third Part of the Countesse of Pembrokes Yuychurch Entituled, Amintas Dale ... (London: 1592).

Galileo, Le opere, ed. Antonio Favaro, 20 vols (Florence: Barbera, 1968 [rpt. 1890-1909]).

$\longrightarrow$, Opere, ed. F. Brunetti, 2 vols (Turin: UTET, 2005).

Gilbert, William, De Magnete, transl. P. Fleury Mottelay (New York: Dover Publications, 1958).

Giovio, Paolo, Ragionamento di mons. Paolo Giovio sopra i motti e i disegni d'arme, e d'amore, che communemente chiamano Imprese (Venice: 1556).

Gratarolo, Guglielmo, The Castel of Memorie, Wherein is Conteyned the Restoring, Augmenting, and Conseruing of the Memorye and Remembraunce, trasl. William Fulwod (London: 1562). 


\section{Bibliography}

Grotius, Hugo, The Freedom of the Seas [Mare Liberum], transl. Ralph Van Deman Magoffin (New York: Oxford University Press, 1916).

Hakewill, George, The Vanitie of the Eie (London: 1608).

Heywood, Thomas, An Apology for Actors, 1612, rpt. (New York: Garland, 1973).

Holland, Philemon, The Historie of the World, translation of Pliny, Historia Naturalis (London: 1601).

Hooker, Richard, Of the Laws of Ecclesiasticall Polity (New York: Everyman Library, 1969).

Hoskins, John, Directions for Speech and Style, 1599, ed. Hoyt H. Hudson (Princeton: Princeton University Press, 1935).

Huloet, Richard, Huloets Dictionarie Newelye Corrected, Amended, Set in Order and Enlarged [...] By Iohn Higgins (London: 1572).

St. Ignatius of Loyola, Esercizi spirituali. Ricerca sulle fonti, ed. Pietro Schiavone (Cinisello Balsamo, Milan: San Paolo, 1995).

Jones, Inigo, Three Volumes Annotated by Inigo Jones: Vasari’s 'Lives' (1568), Plutarch's 'Moralia' (1614), Plato's 'Republic' (1554), ed. A.W. Johnson (Åbo: Åbo Akademi University Printing Press, 1997).

Jonson, Ben, "Discoveries", in The Cambridge Edition of the Works of Ben Jonson, ed. Lorna Hutson, vol. 7 (Cambridge: Cambridge University Press, 2012).

Junius, Francis, The Painting of the Ancients - De Pictura veterum according to the English translation (1638), ed. Keith Aldrich, Philipp Fehl, and Raina Fehl (Berkeley, Los Angeles, and Oxford: University of California Press, 1991).

Leigh, Gerard, Accedence of Armorie (London: 1591).

Leonardo, Trattato della pittura, 1550, ed. A. Borzelli (Lanciano: Carabba, 1947).

Lomazzo, Paolo Giovanni, A Tracte Containing the Artes of Curious Paintinge (1598), Richard Haydocke's translation of Trattato dell'arte della pittura (1584) (Amsterdam and New York: Da Capo Press, 1969).

Linche, Richard, The Fountaine of Ancient Fiction, translation of Vincenzo Cartari, Imagini de i dei de gli antichi (London: 1599).

Mancini, Giulio, Considerazioni sulla Pittura, ed. A. Marucchi and L. Salerno (Rome: Accademia Nazionale dei Licei, 1956-57).

Marlowe, Christopher, Tamburlaine, Parts One and Two, ed. Anthony B. Dawson (London: Bloomsbury Methuen Drama, 1997).

Molanus, Johannes, De Picturis et Imaginibus Sacris (Louvain: 1570).

Montaigne, Michel de, The Essayes of Michael Lord de Montaigne, transl. John Florio, ed. A.R. Waller, 3 vols (London: Everyman's Library, Dent, 1910).

— Essais, éd. Maurice Rat, 2 vols (Paris: Classiques Garnier, 1962).

More, Thomas, The English Works of Sir Thomas More (London and New York: Eyre Spottiswoode-Lincoln MacVeagh, 1931).

- "The Supplication of Souls", in The Yale Edition of the Complete Works of St. Thomas More (New Haven and London: Yale University Press, 1990).

Norgate, Edward, Miniatura or the Art of Limning, ed. Martin Hardie (Oxford: Oxford University Press, 1918).

- - A Treatise Concerning the Arte of Limning, together with A More Compendious Discourse Concerning Ye Art of Limning by Edward Norgate, ed. R.K.R. Thornton and T.G.S. Cain (Ashington: Mid Northumberlands Arts Group, 1981). 
Norton, Thomas, The Ordinall of Alchimy (London: 1477).

Ovid, Ovid's Metamorphoses. The Arthur Golding Translation 1567, ed. John Frederick Nims (Philadelphia: Paul Dry Books, 2000).

Patrologiae Cursus Completus, Series Latina: Supplementum ii, éd. A. Hamman (Paris: Éditions Garnier, 1960).

Peacham, Henry, The Arte of Drawing with the Pen (London: 1606).

- The Compleat Gentleman (Oxford: Clarendon Press, 1906 [1634]).

Perkins, William, Works (London: 1603).

Petrarca, Francesco, Canzoniere, ed. Marco Santagata (Milan: Mondadori, 2006 [1996]).

Picinelli, Filippo, Mondo simbolico (Milan: 1654).

Plutarch, The Philosophie, Commonlie Called, the Morals, transl. P. Holland (London: 1603).

- Shakespeare's Plutarch, ed. C.F. Tucker Brooke (London: Chatto \& Windus, 1909).

Prynne, William, Histrio-mastix, The Player's Scourge; or Actors Tragedie (London: 1633).

Puttenham, George, The Art of English Poesie, ed. Frank Whigham and Wayne A. Rebhorn (Ithaca and London: Cornell University Press, 2007).

Quersitanus, Joseph, The Practise of Chymicall, and hermetical Physicke... translated into English by Thomas Timme, Minister (London: 1605).

Raleigh, Walter, The History of the World (London: 1614).

Ripa, Cesare, Iconologia, ovevero descrittione d'imagini delle virtù, vitii, affetti, passioni humane, corpi celesti, Mondo e sue parti (Padua: 1611), facs. edition (New York: Garland, 1976).

Ripley, George, The Compound of Alchymy. Or The Ancient Hidden Art of Archemie: Conteining the Right \& Perfectest Meanes to make the PHILOSOPHERS STONE, Aurum Potabile, with other Excellent Experiments (London: 1591).

Salutati, Coluccio, De Laburis Herculis, ed. B.L. Ullman, 2 vols (Zurich: Thesaurus Mundi, 1951).

Salviati, Lionardo, Opere del cavaliere Lionardo Salviati, 4 vols (Milan: Società tipografica de' Classici italiani, 1810).

Sandys, George, Ouids Metamorphosis Englished, Mythologized and Represented in Figures (London: 1632).

Scritti d'arte del Cinquecento, ed. Paola Barocchi, 3 vols (Milan and Naples: Ricciardi, 1971-77).

Shaftesbury, the Third Earl of (Antony Ashley Cooper), Second Characters, or, the Language of Forms, ed. B. Rand (Cambridge: Cambridge University Press, 1914).

Sidney, Philip, The Countess of Pembroke's Arcadia (London: Sampson, New York: Hurd \& Houghton, 1868).

—, An Apology for Poetry, or The Defense of Poesy, ed. G. Shepherd (Manchester: Manchester University Press, 1980).

Spenser, Edmund, The Complete Poetic Works of Edmund Spenser, ed. R.E.N. Dodge (Cambridge, MA: Harvard University Press, 1908).

Sturm, Johannes, Nobilitas Literata (Rihel: 1549).

Tasso, Torquato, Discourses on the Heroic Poem (Discorsi del poema eroico), transl. Mariella Cavalchini and Irene Samuel (Oxford: Clarendon Press, 1973). 


\section{Bibliography}

Thomas, William, History of Italy (London: 1549).

Topsell, Edward, The Historie of Foure-Footed Beasts (London: 1607).

Trattati d'arte del Cinquecento fra Manierismo e Controriforma, ed. Paola Barocchi, 3 vols (Bari: Laterza, 1962).

Trattati di poetica e retorica del Cinquecento, ed. Bernard Weinberg, 4 vols (Bari: Laterza, 1970-74).

Tudor Royal Proclamations, ed. Paul L. Hughes and James F. Larkin (New Haven: Yale University Press, 1964).

Varchi, Benedetto, Lezzione nella quale si disputa della maggioranza delle arti e qual sia più nobile, la scultura o la pittura (Florence: 1556).

Venner, Thomas, Via Recta ad Vitam Longam. Or, a Treatise wherein the right way and best manner of living for attaining a long and healthfull life, is clearly demonstrated (London: 1650).

Whetstone, George, Promos and Cassandra (London: 1578).

Willis, Timothy, The Search of Causes. Containing a Theophysicall Inuestigation of the Possibilie of Transmutatorie Alchemie (London: 1616).

Wither, George, A Collection of Emblemes, Ancient an Moderne (1635) (Columbia: University of South Carolina Press, 1975).

Wotton, Henry, The Elements of Architecture: A Facsimile Reprint of the First Edition (London: 1624), ed. F. Hard (Charlottesville: Folger Shakespeare Library, 1968).

Zetzner, Lazarus, Theatrum Chemicum, precipuos selectorum auctorum tractatus de chemiae et lapidis philosophici antiquitate, veritate, jure, praestantia, \& operationibus, continens (Argentorati: 1613-61).

\section{Secondary Works}

Abraham, Lyndall, "Alchemical Reference in Antony and Cleopatra", Sydney Studies, 8(1982): 100-4.

Ackerman, A.L. jr, "Visualizing Hamlet's Ghost: the Spirit of Modern Subjectivity", Theatre Journal, 53(2001): 119-44.

Aebischer, Pascale, "Titus Andronicus: Spectacular Obscenities", in Shakespeare's Violated Bodies (Cambridge: Cambridge University Press, 2004), pp. 24-63.

Agamben, Giorgio, State of Exception, transl. Kevin Kittel (London and Chicago: The University of Chicago Press, 2007).

Aiton, Eric, Astronomy in Harriot's Time, The Durham Thomas Harriot Seminar, Occasional Paper no. 14, 1994. Alpers, Svetlana and Paul, "Ut Pictura Noesis? Criticism in Literary Studies and Art History”, New Literary History, 3, 3(1972): 437-58.

Anderson, Thomas P., "Reading Martyred History in Titus Andronicus", in Performing Early Modern Trauma from Shakespeare to Milton (Aldershot: Ashgate, 2006), pp. 19-56.

Andrews, Lew, Story and Space in Renaissance Art: The Rebirth of Continuous Narrative (Cambridge: Cambridge University Press, 1995).

Argan, Giulio Carlo, “Il 'realismo' nella poetica del Caravaggio”, in Scritti di storia dell'arte in onore di Lionello Venturi, vol. II (Rome: De Luca, 1956), pp. 25-41.

Ariès, Philippe, L’homme devant la mort (Paris: Seuil, 1977). 
Armstrong, Philip, "Watching Hamlet Watching: Lacan, Shakespeare, and the Mirror/Stage”, in Alternative Shakespeares, ed. Terence Hawkes, vol. 2 (London and New York: Routledge, 1996), pp. 216-37.

Askew, Pamela, Caravaggio's Death of the Virgin (Princeton: Princeton University Press, 1990).

Aston, Margaret, England's Iconoclasts, 2 vols (Oxford: Clarendon Press, 1988).

- The King's Bedpost: Reformation and Iconography in a Tudor Group Portrait (Cambridge: Cambridge University Press, 1993).

Azzolini, Monica, The Duke and the Stars. Astrology and Politics in Renaissance Milan (Cambridge, MA and London: Harvard University Press, 2013).

Bahti, Timothi, "Ambiguity and Indeterminacy: The Juncture", Comparative Literature, 38(1986): 209-23.

Bailey, Amanda, "Personification and the Political Imagination of A Midsummer Night's Dream", in The Oxford Handbook of Shakespeare and Embodiment: Gender, Sexuality, and Race, ed. Valerie Traub (Oxford: Oxford University Press, 2016), pp. 400-18.

Baldwin, Geoff, "Individual and Self in the Late Renaissance", The Historical Journal, 44, 2(2001): 341-64.

Baltrušaitis, Jurgis B., Aberrations: essai sur la légende des formes (Paris: Flammarion, 1983).

Bambach, Carmen C., Drawing and Painting in the Italian Renaissance Workshop: Theory and Practice, 1300-1660 (Cambridge: Cambridge University Press, 1999).

Bann, Stephen, The True Vine: On Visual Representation and the Western Tradition (Cambridge: Cambridge University Press, 1989).

Barasch, Moshe, Light and Color in the Italian Renaissance Theory of Art (New York: New York University Press, 1978).

— "How the Hidden Becomes Visible", in The Language of Art: Studies in Interpretation (New York and London: New York University Press, 1997), pp. 288-301.

Bardon, Françoise, Caravage ou l'expérience de la matière (Paris: Presses Universitaires de France, 1978).

Barelli, Emma Spina, Teorici e scrittori d'arte tra manierismo e barocco (Milan: Editrice Vita e Pensiero, 1966).

Barkan, Leonard, The Gods Made Flesh: Metamorphosis and the Pursuit of Paganism (New Haven: Yale University Press, 1986).

Bartsch, Shadi, "The Philosopher as Narcissus: Vision, Sexuality and Self-Knowledge in Classical Antiquity", in Visuality Before and Beyond the Renaissance, ed. Robert S. Nelson (Cambridge: Cambridge University Press, 2000), pp. 70-97.

Bate, Jonathan, Shakespeare's Ovid (Oxford: Clarendon Press, 1994).

Baxandall, Michael, Giotto and the Orators. Humanist Observers of Painting in Italy and the Discovery of Pictorial Composition (Oxford: Clarendon Press, 2006 [1971]).

- Painting and Experience in Fifteenth-Century Italy: A Primer in the Social History of Pictorial Style (Oxford: Oxford University Press, 1991), pp. 29-108.

Becker, Andrew Sprague, The Shield of Achilles and the Poetics of Ekphrasis (Lanham: Rowman \& Littlefield, 1995). 


\section{Bibliography}

Bek, Lise, "Rhetorics to Aesthetics: Organization of Sight and Landscape as an Invention of Renaissance Humanism", in Regardeurs, flâneurs et voyageurs dans la peinture (Paris: Publications de la Sorbonne, 2015), pp. 113-28.

Bell, Ilona, "Mirror Tropes and Renaissance Poetry", in Renaissance Tropologies. The Cultural Imagination of Early Modern England, ed. Jeanne Shami (Pittsburg: Duquesne University Press, 2008), pp. 229-53.

Belsey, Catherine, Romeo and Juliet. Language \& Writing (London: Bloomsbury, 2014).

Bentley-Cranch, Dana, The Renaissance Portrait in France and England (Paris: Honoré Champion, 2004).

Berenson, Bernard, Del Caravaggio, delle sue incongruenze e della sua fama (Florence: Electa Editrice, 1951).

Beretta, Ilva, "The World's a Garden": Garden Poetry of the English Renaissance (Göteborg: Graphic Systems AB, 1993).

Beretta, Marco, "The Role of Symbolism from Alchemy to Chemistry", in Non-Verbal Communication in Science Prior to 1900, ed. R.G. Mazzolini (Florence: Leo S. Olschki, 1993), pp. 279-319.

Bernardini, Maria Grazia, "Simbolismo e spiritualità nell'arte di Caravaggio", in Caravaggio: l'immagine del divino, ed. Denis Mahon (Rome: Romartificio, 2007), pp. 156-85.

Berry, Edward, Shakespeare and the Hunt: A Cultural and Social Study (Cambridge: Cambridge University Press, 2001).

Berry, Philippa, Shakespeare's Feminine Endings: Disfiguring Death in the Tragedies (London and New York: Routledge, 1999).

Bersani, Leo, and Ulysse Dutoit, Caravaggio's Secrets (Cambridge, MA and London: The MIT Press, 1998).

Besserman, Lawrence, "Introduction: Sacred and Secular in Medieval and Early Modern Cultures: Issues and Approaches", in Sacred and Secular in Medieval and Early Modern Cultures: New Essays, ed. Lawrence Besserman (Houndmills: Palgrave Macmillan, 2006), pp. 1-15.

Bevington, David, "Dream and Vision in Shakespeare's Plays", in Dreams and Visions: An Interdisciplinary Enquiry, ed. Nancy van Deusen (Leiden and Boston: Brill, 2010), pp. 259-79.

Birrell, Erica, "A Midsummer Night's Symposium: Translating Platonic Love in A Midsummer Night's Dream", in Shakespeare and the Translation of Identity in Early Modern England, ed. Liz Oakley-Brown (London: Continuum, 2011), pp. 46-73.

Blanchard, Jean-Vincent, "La catoptrique dévote: les miroirs et l'éloquence sacrée au début du XVII" siècle", in Le siècle de la lumière 1600-1715, éd. Christian Biet et Vincent Jullien (Fontenay-aux-Roses: ENS Editions, 1997), pp. 183-93.

Boehrer, Bruce, Shakespeare among the Animals. Nature and Society in the Drama of Early Modern England (Basingstoke: Palgrave Macmillan, 2002).

Bologna, Ferdinando, L'incredulità del Caravaggio e l'esperienza delle cose naturali (Turin: Boringhieri, 2006 [1992]).

Boschloo, Anton W.A., "Caravaggio and the "Copying of Nature", in The Limits of Artistic Freedom: Criticism of Art in Italy from 1500 to 1800, transl. Robert Symonds (Leiden: Primavera Pers, 2008), pp. 122-39. 
Botwinick, Aryeh, "Interpretation and Indeterminacy", in Indeterminacy: The Mapped, the Navigable, and the Uncharted, ed. Jose V. Ciprut (Cambridge, MA and London: The MIT Press, 2008), pp. 79-100.

Blake, Erin C., "Shakespeare, Portraiture, Painting and Prints", in The Edinburgh Companion to Shakespeare and the Arts, ed. Mark Thornton Burnett, Adrian Streete, and Ramona Wray (Edinburgh: Edinburgh University Press, 2011), pp. 409-34.

Blumenberg, H., Shipwreck with Spectator: Paradigm of a Metaphor for Existence, transl. S. Rendall (Cambridge and London: MIT Press, 1997).

Boulnois, O., "Ego ou Cogito? Doute, tromperie divine et certitude de soi, du XIV ${ }^{\mathrm{e}}$ au $\mathrm{XVI}^{\mathrm{e}}$ siècles", in Génealogies du sujet: de Saint Anselme à Malebranche, éd. O. Boulnois (Paris: Vrin, 2007), pp. 171-213.

Boyle, Jen E., Anamorphosis in Early Modern Literature. Mediation and Affect (Farnham: Ashgate, 2010).

Boyle, Marjorie O'Rourke, “Cusanus at Sea: The Topicality of Illuminative Discourse", The Journal of Religion, 71, 2(1991): 180-201.

Braider, Christopher, Refiguring the Real: Picture and Modernity in Word and Image 1400-1700 (Princeton: Princeton University Press, 1993).

- "The Fountain of Narcissus: The Invention of Subjectivity and the Pauline Ontology of Art in Caravaggio and Rembrandt", Comparative Literature, 50, 4(1998): 286-315.

Brayton, Dan, Shakespeare's Ocean: An Ecocritical Exploration (Charlottesville and London: University of Virginia Press, 2012).

Brobick, Benson, The Fated Sky. Astrology in History (New York and London: Simon \& Schuster, 2005).

Bromley, James M., Intimacy and Sexuality in the Age of Shakespeare (Cambridge: Cambridge University Press, 2012).

Bronfen, Elisabeth, "Extimate Violence: Shakespeare's Night World”, Shakespeare Jabrbuch, 143(2007): 132-46.

Brusati, C., K.A.E. Enenkel, and W.S. Melion (ed.), The Authority of the Word. Reflecting on Image and Text in Northern Europe, 1400-1700 (Leiden and Boston: Brill, 2012).

Bryson, Norman, Looking at the Overlooked. Four Essays on Still Life Painting (London: Reaktion Books, 1990).

Buckley, G.T., "What Star Was Westward from the Pole?”, Notes \& Queries, 10(1963): 412-13.

Buhler, Stephen M., “Marsilio Ficino's De stella magorum and Renaissance Views of the Magi”, Renaissance Quarterly, 43, 2(1990): 348-71.

Bullard, Melissa Meriam, "The Inward Zodiac: A Development in Ficino's Thought on Astrology", Renaissance Quarterly, 43, 4(1990): 687-708.

Burgard, Peter J., "The Art of Dissimulation: Caravaggio's Calling of St Matthew", Pantheon, 56(1998): 95-102.

Burke, Peter, "Representations of the Self from Petrarch to Descartes", in Rewriting the Self. Histories from the Renaissance to the Present, ed. Roy Porter (London and New York: Routledge, 1997), pp. 17-28.

Butor, Michel, "Il canestro dell'Ambrosiana", in Saggi sulla pittura: Holbein, Caravaggio, Hokusai, Picasso, Mondrian, Rothko (Milan: Abscondita, 2001), pp. 25-46.

Buxton, John, Elizabethan Taste (London: Macmillan, 1963). 
Cabantous, Alain, Histoire de la nuit: XVII $-X V I I I^{e}$ siècle (Paris: Fayard, 2009).

Callaghan, Dympna, “(Un)natural Loving: Swine, Poets and Flowers in Venus and Adonis", in Textures of Renaissance Knowledge, ed. Philippa Berry and Margaret Tudeau-Clayton (Manchester and New York: Manchester University Press, 2003), pp. 58-80.

Calvesi, Maurizio, "Caravaggio o la ricerca della salvazione”, in Storia dell'arte, 3, 9-10(1971): 93-141.

- (ed.), L'ultimo Caravaggio e la cultura artistica a Napoli in Sicilia e a Malta (Siracusa: Ediprint, 1987).

- Le realtà del Caravaggio (Turin: Einaudi, 1990).

— - "Trasparente l'autore come il soggetto. Ancora sul Caravaggio del Casino Ludovisi a Roma", Art e Dossier, 60(1991): 22-6.

—, "Il sacro e il 'sonoro' nei dipinti giovanili del Caravaggio. Con una appendice e un quesito", in Dal Caravaggio ai Caravaggeschi, ed. Maurizio Calvesi and Alessandro Zuccari (Rome: CAM Editrice, 2010), pp. 123-34.

Camille, M., "Before the Gaze: The Internal Senses and Late Medieval Practices of Seeing", in Visuality Before and Beyond the Renaissance: Seeing as Others Saw, ed. R.S. Nelson (Cambridge: Cambridge University Press, 2000), pp. 197-223.

Camiz, Franca Trinchieri, "Death and Rebirth in Caravaggio's Martyrdom of St Matthew", Artibus et Historiae, 11, 22(1990): 89-105.

Camporesi, Piero, The Fear of Hell: Images of Damnation and Salvation in Early Modern Europe (University Park, PA: Pennsylvania State University Press, 1991).

Candela, G., "An Overview of the Cosmology, Religion and Philosophical Universe of Giordano Bruno", Italica, 75, 3(1998): 348-64.

Cantor, Paul A., "The Cause of Thunder. Nature and Justice in King Lear", in King Lear. New Critical Essays, ed. Jeffrey Kahan (New York and London: Routledge, 2008), pp. 231-52.

Cappelletti, Francesca, Caravaggio: un ritratto somigliante (Milan: Electa, 2010).

Carlino, Andrea, "Marsia, Sant'Antonio ed altri indizi: il corpo punito e la dissezione tra Quattro e Cinquecento", in Le corps à la Renaissance, éd. Jean Ceard, Marie-Madeleine Fontaine et Jean-Claude Margolin (Paris: Aux Amateurs de Livres, 1990), pp. 129-38.

Carman, Charles H., Leon Battista Alberti and Nicholas Cusanus. Towards an Epistemology of Vision for Italian Renaissance Art and Culture (Farnham: Ashgate, 2014).

_- "Meanings of Perspective in the Renaissance: Tensions and Resolutions", in Renaissance Theories of Vision, ed. John Shannon Hendrix and Charles H. Carman (London and New York: Routledge, 2016), pp. 31-44.

Carroll, William C., The Metamorphoses of Shakespearean Comedy (Princeton: Princeton University Press, 1985).

Cassola, Arnold, "On the Meaning of 'Enciel'd' in Measure for Measure", English Language Notes, 27(1990): 22-27.

Castellotti, Marco Bona, Il paradosso di Caravaggio (Milan: Biblioteca Universale Rizzoli, 1998).

Cefalu, Paul, Moral Identity in Early Modern English Literature (Cambridge: Cambridge University Press, 2004). 
Cerati, Carla, "Volti e corpi di Caravaggio. La natura dei modelli”, in Caravaggio a Roma. Una vita dal vero, ed. Michele Di Sivo and Orietta Verdi (Rome: De Luca Editori d'Arte, 2011), pp. 137-42.

Chamberlain, Richard, "The Grimace of Ambiguity: Unambiguity and the Critics", Linguistics and Literature Studies, 3, 1(2015): 1-10.

Change and Continuity in Early Modern Cosmology, ed. Patrick J. Boner (Dordrecht: Springer, 2011).

Chapman, Alison A., "Marking Time: Astrology, Almanacs, and English Protestantism”, Renaissance Quarterly, 60, 4(2007): 1273 (87-106).

Chapman, Allan, Gods in the Sky. Astronomy, Religion and Culture from the Ancients to the Renaissance (London: Macmillan, 2002).

Charnes, Linda, Notorious Identity: Materializing the Subject in Shakespeare (Cambridge, MA and London: Harvard University Press, 1993).

Charney, Maurice, "Analogy and Infinite Regress in Hamlet”, in Psychoanalytic Approaches to Literature and Film, ed. M. Charney and J. Peppen (Rutherford, NJ: Fairleigh Dickinson University Press, 1987), pp. 156-67.

Chaudhury, Sukanta, Infirm Glory. Shakespeare and the Renaissance Image of Man (Oxford: Clarendon Press, 1981).

Cheney, L. De Girolami, and John Hendrix (ed.), Neoplatonic Aesthetics. Music, Literature \& the Visual Arts (New York: Peter Lang, 2004).

Cherry, Peter, "In the Presence of Things. Two Centuries of Still-life Painting", in In the Presence of Things. Four Centuries of European Still-Life Painting (Lisbon: Calouste Gulbenkian Foundation, 2010), pp. 12-43.

Choné, Paulette, "L'académie de la nuit. Louange et science de l'ombre au XVII siècle”, in L’Âge d'or du nocturne, ed. P. Choné, J.-C, Boyer, R.E. Spear, and I. Lavin (Paris: Gallimard, 2001), pp. 17-61.

Christiansen, Keith, A Caravaggio Rediscovered: The Lute Player (New York: The Metropolitan Museum of Art, 1990).

Cinotti, Mia, Michelangelo Merisi detto il Caravaggio. Tutte le opere (Bergamo: Poligrafiche Bolis, 1983).

Ciprut, José V., "Definitions, Distinctions, and Dilemmas", in Indeterminacy: The Mapped, the Navigable, and the Uncharted, ed. José V. Ciprut (Cambridge, MA and London: The MIT Press, 2008), pp. 79-100.

Clark, Stuart, Vanities of the Eye: Vision in Early Modern European Culture (Oxford: Oxford University Press, 2007).

Clarke, Danielle, "Love, Beauty, and Sexuality", in The Cambridge Companion to Shakespeare's Poetry, ed. Patrick Cheney (Cambridge: Cambridge University Press, 2007), pp. 181-201.

Coates, Peter, Nature: Western Attitudes since Ancient Times (London: Polity, 1998).

Cobb, Christopher, "Storm Versus Story: Form and Affective Power in Shakespeare's romances", in Shakespeare and Historical Formalism, ed. Stephen Cohen (Aldershot: Ashgate, 2007), pp. 95-124.

Coffin, Charlotte, "An Echo Chamber for Narcissus: Mythological Rewritings in Twelfth Night", Cahiers Élisabéthains, 66(2004): 23-8.

Comi, Armando, "Il corpo di Maria tra XV-XVI secolo", in Il pensiero simbolico nella prima età moderna, ed. Annarita Angelini and Pierre Caye (Florence: Olschki, 2007), pp. 197-221.

Comito, Terry, The Idea of the Garden in the Renaissance (Hassocks: The Harvester Press, 1978). 


\section{Bibliography}

Cook, Eleanor, “Ambiguity and the Poets”, Connotations, 18, 1-3(2008/2009): 230-45.

Coronato, Rocco, "The Unfinished in Michelangelo and Othello", in Shakespeare, Italy, and Transnational Exchange, ed. Enza De Francisci and Chris Stamatakis (Abingdon and New York: Routledge, 2017), pp. 65-79.

Corrain, Lucie, "Cristo nell'orto di Caravaggio: un esempio di narrazione prodromica", in Caravaggio nel IV centenario della Cappella Contarelli, ed. Caterina Volpi (Città di Castello: Petruzzi Stampa, 2002), pp. 221-31.

Costa de Beauregard, Raphaëlle, Nicholas Hilliard et l'imaginaire elisabethain 1547-1619 (Paris: Editions du Centre National de la Recherche Scientifique, 1991).

Cox, John D., The Devil and the Sacred in English Drama, 1350-1642 (Cambridge: Cambridge University Press, 2000).

Crane, Mary Thomas, "Roman World, Egyptian Earth: Cognitive Difference and Empire in Shakespeare's Antony and Cleopatra", Comparative Drama, 43, 1(2009): 1-18.

Cregan, Kate, The Theatre of the Body. Staging Death and Embodying Life in Early-Modern London (Turnhout: Brepols, 2009).

Crombie, Alistair C., "Science and the Arts in the Renaissance: The Search for Truth and Certainty, Old and New", in Science and the Arts in the Renaissance, ed. John W. Shirley and F. David Hoeniger (Washington: The Folger Shakespeare Library; London and Toronto: Associated University Presses, Folger Books, 1985), pp. 15-26.

Crystal, Ben, and David Crystal, Shakespeare's Words: A Glossary and Language Companion (www.shakespeareswords.com, last accessed on May 9, 2017).

Cuddy, Neil, "Dynasty and Display: Politics and Painting in England, 1530-1630”, in Dynasties: Painting in Tudor and Jacobean England 1530-1630, ed. Karen Hearn (London: Tate Publishing, 1995), pp. 11-20.

Cummings, Brian, "Iconoclasm and Bibliophobia in the English Reformations, 1521-1558", in Images, Idolatry, and Iconoclasm in Late Medieval England: Textuality and the Visual Image, ed. Jeremy Dimmick, James Simpson, and Nicolette Zeeman (Oxford: Oxford University Press, 2002), pp. 185-206.

Cummings, Frederick, “The Meaning of Caravaggio's 'Conversion of Maddalen'”, The Burlington Magazine, 116, 859 (October 1974): 562-564, 569, 570.

Curtis, Mary Ann, "The Joining of Male and Female: An Alchemical of Transmutation in Antony and Cleopatra", The Upstart Crow, 12(1992): 116-26.

Dahlquist, Mark, "Strange Love. Funerary Erotics in Romeo and Juliet", in Sexuality and Memory in Early Modern England: Literature and the Erotics of Recollection, ed. John S. Garrison and Kyle Pivetti (Abingdon and New York: Routledge, 2016), pp. 129-43.

Dalli Regoli, Gigetta, Il gesto e la mano: convenzione e invenzione nel linguaggio figurativo fra Medioevo e Rinascimento (Florence: Olschki, 2000).

Danesi Squarzina, S., "Pittura e rappresentazione: Caravaggio e il teatro della crudeltà”, in Caravaggio. La luce nella pittura lombarda, ed. C. Strinati and R. Voudret (Milan: Electa, 2000), pp. 89-101.

Darrigol, Olivier, A History of Optics: From Greek Antiquity to the Nineteenth Century (Oxford: Oxford University Press, 2012).

Daston, Lorraine, "The Empire of Observation, 1600-1800", in Histories of Scientific Observation, ed. Lorraine Daston and Elizabeth Lunbeck (Chicago and London: The University of Chicago Press, 2011), pp. 81-113. 
Davidson, Clifford, “The Anti-Visual Prejudice”, in Iconoclasm vs. Art and Drama, ed. Clifford Davidson and Ann Eljenholm Nichols (Kalamazoo, MI: Medieval Institute Publications, 11, 1989), pp. 33-46.

- "The Fate of the Damned in English Art and Drama", in The Iconography of Hell, ed. Clifford Davidson and Thomas H. Seiler (Kalamazoo, MI: Western Michigan University, 1992), pp. 41-66.

De Boer, Wietse, and Christine Göttler (ed.), Religion and the Senses in Early Modern Europe (Boston and Leiden: Brill, 2013).

De Giorgio, Cynthia, and Keith Sciberras (ed.), Caravaggio and Paintings of Realism in Malta (Valletta: Midsea Books, 2007).

De Grazia, Margreta, Maureen Quilligan, and Peter Stallybrass (ed.), Subject and Object in Renaissance Culture (Cambridge: Cambridge University Press, 1996), pp. 17-42.

Del Bravo, Carlo, "Sul significato della luce nel Caravaggio e in Gianlorenzo Bernini”, Artibus et Historiae, 4, 7(1983): 69-77.

Deleuze, Gilles, and Félix Guattari, A Thousand Plateaus: Capitalism and Schizophrenia, transl. Brian Massumi (Minneapolis: University of Minnesota Press, 1987).

Dempsey, Charles, "Caravaggio e i due stili naturalistici: speculare contro maculare”, in Caravaggio nel IV centenario della Cappella Contarelli, ed. Caterina Volpi (Rome: CAM Editrice, 2002), pp. 185-96.

Deutermann, Allison K., "Hearing Iago's Withheld Confession", in Shakespearean Sensations. Experiencing Literature in Early Modern England, ed. Katharine A. Craik and Tanya Pollard (Cambridge: Cambridge University Press, 2013), 47-63.

Diehl, H., Horrid Image, "Sorry Sight, Fatal Vision: The Visual Rhetoric of Macbeth", Shakespeare Studies, 16(1983): 191-204.

Dillenberger, John, Images and Relics. Theological Perceptions and Visual Images in Sixteenth-Century Europe (New York and Oxford: Oxford University Press, 1999).

Dimit, Robert, "Divine Grace, the Humoral Body, and the 'Inner Self' in Seventeenth-Century France and England", in Space and Self in Early Modern European Cultures, ed. D. Warren Sabean and M. Stefanovska (Toronto: University of Toronto Press, 2012), pp. 153-64.

Doebler, Bettie Anne, 'Rooted Sorrow': Dying in Early Modern England (Rutherford, Madison, and Teaneck: Fairleigh Dickinson University Press; London and Toronto: Associated University Presses, 1994).

Doebler, John, “The Reluctant Adonis: Titian and Shakespeare”, Shakespeare Quarterly, 33, 4(1982): 480-90.

Dronke, Peter and Ursula, "Growth of Literature: The Sea and the God of the Sea”, H.M. Chadwick Memorial Lectures n. 8 (Department of Anglosaxon, Norse and Celtic, University of Cambridge, 1997).

Dubrow, Heather, "A Mirror for Complaints: Shakespeare's Lucrece and Generic Tradition”, in Renaissance Genres: Essays on Theory, History, and Interpretation, ed. Barbara Kiefer Lewalski (Cambridge, MA and London: Harvard University Press, 1986), pp. 399-417.

Duncan Jones, K., “Sidney's Personal Imprese”, Journal of the Warburg and Courtauld Institutes, 33(1970): 321-24.

Dundas, Judith, “'Artificial Strife': Shakespeare and Emulation”, in Pencils Rhetorique: Renaissance Poets and the Art of Painting (Newark: University 


\section{Bibliography}

of Delaware Press; London and Toronto: Associated University Presses, 1993), pp. 54-8.

Duport, Danièle, Le jardin et la nature. Ordre et variété dans la literature de la Renaissance (Genève: Droz, 2002).

Ebert-Schifferer, Sybille, “Caravaggios 'Früchtekorb': das Früheste Stilleben?”, Zeitschrift für Kunstgeschichte, 65(2002): 1-23.

- Caravaggio: The Artist and His Work (Los Angeles: The Paul Getty Museum, 2012).

Edgecombe, R. Stenning, "Mors Viva: Literary Renderings of Life-to-death Transitions", The Modern Language Review, 93(2003): 11-26.

Edwards, Philip, Sea-mark: The Metaphorical Voyage, Spenser to Milton (Liverpool: Liverpool University Press, 1997).

Ekserdjian, David, Alle origini della natura morta (Milan: Electa, 2007).

Elam, Keir, Shakespeare's Pictures. Visual Culture in Drama (London: The Arden Shakespeare, Bloomsbury, 2017).

Les éléments et les métamorphoses de la nature. Imaginaire et symbolique des arts dans la culture européenne $d u X V I^{e}$ au XVIII $I^{e}$ siècle (Paris: William Blake \& Co./Art \& Arts, 2004).

Elton, William R., King Lear and the Gods (Lexington: University Press of Kentucky, 1988).

Engel, William E., Death and Drama in Renaissance England. Shades of Memory (Oxford: Oxford University Press, 2002).

Evans, James, The History and Practice of Ancient Astronomy (Oxford: Oxford University Press, 1998).

Evett, David, Literature and the Visual Arts in Tudor England (Athens and London: The University of Georgia Press, 1990).

Fabiański, Marcin, "Rifrazioni nella pittura al tempo di Caravaggio", Artibus et historiae, 28, 56(2007): 207-23.

Falk, Dan, The Science of Shakespeare: A New Look at the Playwright's Universe (New York: St. Martin's Press, 2014).

Farley-Hills, D. (ed.), Critical Responses to Hamlet 1600-1700 (New York: AMS Press, 1997).

Feerick, J.E., and J.E. Nardizzi, "Introduction: Swervings: On Human Indistinction", in The Indistinct Human in Renaissance Literature, ed. J.E. Feerick and V. Nardizzi (New York: Palgrave MacMillan, 2012), pp. 1-12.

Felperin, Howard, “'Tongue-ti'd Our Queen?': The Deconstruction of Presence in The Winter's Tale", in Shakespeare and the Question of Theory, ed. P. Parker and G. Hartman (New York and London: Routledge, 1993 [1985]), pp. 3-18.

Fiore, Kristina Hermann, "Il Bacchino malato autoritratto del Caravaggio ed altre figure bacchiche degli artisti”, in Caravaggio: nuove riflessioni (Rome: Fratelli Palombi Editori, 1989), pp. 95-134.

Flachman, M. "Fitted for Death: Measure for Measure and the Contemplatio Mortis", English Literary Renaissance, 22(1992): 222-41.

Foister, Susan, "Sixteenth-Century English Portraiture and the Idea of the Classical”, in Albion's Classicism: The Visual Arts in Britain, 1550-1660, ed. Lucy Gent (New Haven, CT-London: The Yale University Press, 1995), pp. 163-80. 
Fowler, Alaistair, Time's Purpled Masquers. Stars and the Afterlife in Renaissance English Literature (Oxford: Clarendon Press, 1996).

Fox, Michael V., “The Uses of Indeterminacy”, Semeia, 71, 2(1995): 173-91.

Frainkel, Lisa, Reading Shakespeare's Will: The Theology of Figure from Augustine to the Sonnets (New York: Columbia University Press, 2002), pp. 159-236.

Frascarelli, Dalma, “'Admirabiles fructus'. Nuove proposte per una lettura iconologica del Ragazzo con il cesto di frutta e della Canestra", in Da Caravaggio ai caravaggeschi, ed. Maurizio Calvesi and Alessandro Zuccari (Rome: CAM Editrice, 2009), pp. 135-68.

Freccero, John, "Medusa: The Letter and the Spirit", Yearbook of Italian Studies, 2 (1972): 1-18.

Freedman, Barbara, Staging the Gaze: Postmodernism, Psychoanalysis, and Shakespearean Comedy (Ithaca: Cornell University Press, 1991).

Freeman, Donald C., “'The Rack Dislimns': Schema and Metaphorical Pattern in Antony and Cleopatra", Poetics Today, 20, 3(1999): 443-60.

Fried, Michael, The Moment of Caravaggio (Princeton and Oxford: Princeton University Press, 2010).

Friedberg, Anne, The Virtual Window: From Alberti to Windows (Cambridge, MA-London: The MIT Press, 2006).

Friedlaender, Walter, Caravaggio Studies (New York: Schocken Books, 1969 [1955]).

Frontisi-Ducroux, Françoise, Du masque au visage: aspects de l'identité en Grèce ancienne (Paris: Flammarion, 1995).

Fudge, Erica, Ruth Gilbert, and Susan Wiseman (ed.), At the Borders of the Human. Beasts, Bodies and Natural Philosophy in the Early Modern Period (Houndmills: Macmillan, 1999).

Gabriele, Mino, Alchimia e iconologia (Udine: Forum, 1997).

Gallo, Marco, "Il Sacrificio di Isacco' di Caravaggio come meccanica della satisfactio", in Michelangelo Merisi da Caravaggio. La vita e le opere attraverso $i$ documenti, ed. Stefania Macioce (Rome: Logart Press, 1996), pp. 331-360.

Garin, Eugenio, Astrology in the Renaissance. The Zodiac of Life, transl. Carolyn Jackson and June Allen (London: Routledge \& Kegan Paul, 1983).

Gash, John, Caravaggio (London: Jupiter Books, 1980).

Gatti, Hilary, "Minimum and Maximum, Finite and Infinite: Bruno and the Northumberland Circle", Journal of the Warburg and Courtauld Institutes, 48 (1985): 144-63.

- "Bruno and Shakespeare: Hamlet", in Essays on Giordano Bruno (Princeton: Princeton University Press, 2011), pp. 140-60.

Gaunt, William, Court Painting in England from Tudor to Victorian Times (London: Constable, 1980).

Gélis, Jacques, "Le corps, l'Église, le sacré”, in Histoire du corps, vol. I, De la Renaissance aux Lumières, éd. Alain Corbin, Jean-Jacques Courtine, and Georges Vigarello (Paris: Seuil, 2005), pp. 17-107.

Gent, Lucy, Picture and Poetry 1560-1620: Relations Between Literature and the Visual Arts in the English Renaissance (Leamington Spa: James Hall, 1981).

English Culture c.1540-1660 (London: Reaktion Books, 1990). 
(ed.), Albion's Classicism: The Visual Arts in Britain, 1550-1660 (New Haven and London: The Yale University Press, 1995).

Geonget, Stéphan, La notion de perplexité à la Renaissance (Genève: Droz, 2006).

Gibbons, Brian, Shakespeare and Multiplicity (Cambridge: Cambridge University Press, 1993).

Gilbert, Creighton, Caravaggio and His Two Cardinals (University Park, PA: The Pennsylvania State University Press, 1995).

Gill, Meredith J., Angels and the Order of Heaven in Medieval and Renaissance Italy (Cambridge: Cambridge University Press, 2014).

Gillies, John, Shakespeare and the Geography of Difference (Cambridge: Cambridge University Press, 1994).

Gingerich, O., "Great Conjunctions, Tycho, and Shakespeare", Sky and Telescope, 59(1981): 394-95.

Glatigny, Pascal Dubourg, "Représenter l'ombre au XVI $\mathrm{X}^{\mathrm{e}}$ siècle. Voir, savoir et dessiner", in Lumière et vision dans les sciences et dans les arts. De l'Antiquité au XVII siècle, éd. Michel Hochmann et Danielle Jacquart (Genève: Droz, 2010), pp. 231-55.

Goldstein, N.L., "Love's Labour's Lost and the Renaissance Vision of Love", in Shakespeare and the Literary Tradition, ed. S. Orgel and S. Keilen (New York and London: Garland Publishing, 1999), pp. 201-16.

Gombrich, Ernst H., Symbolic Images: Studies in the Art of the Renaissance (London: Phaidon, 1972).

Goodland, Katharine, "Inverting the Pietà in Shakespeare's King Lear", in Marian Moments in Early Modern British Drama, ed. Regina Buccola and Lisa Hopkins (Aldershot: Ashgate, 2007), pp. 47-74.

Gordon, Andrew, and Thomas Rist (eds.), The Arts of Remembrance in Early Modern England: Memorial Cultures of the Post Reformation (Farnahm: Ashgate, 2013).

Gordon, Bruce, "The Renaissance Angel", in Angels in the Early Modern World, ed. P. Marshall and A. Walsham (Cambridge: Cambridge University Press, 2006), pp. 41-63.

Gorringe, T.J., Earthly Visions: Theology and the Challenges of Art (New Haven and London: Yale University Press, 2011).

Göttler, Christine, Last Things. Art and the Religious Imagination in the Age of Reform (Turnhout: Brepols, 2010).

Grabes, Herbert, The Mutable Glass: Mirror Imagery in Titles and Texts of the Middle Ages and English Renaissance, transl. Gordon Collier (Cambridge: Cambridge University Press, 1982).

Grady, Hugh, Shakespeare's Universal Wolf (Oxford: Clarendon, 1996).

_- "A Midsummer Night's Dream - Eros and the Aesthetic", in Shakespeare and Impure Aesthetics (Cambridge: Cambridge University Press, 2009), pp. 47-89.

Graff, Gerald, "Determinacy/Indeterminacy", in Critical Terms for Literary Studies, ed. Frank Lentricchia and Thomas Mclaughlin (Chicago: University of Chicago Press, 1995 [1990]), pp. 163-76.

Graham-Dixon, Andrew, Caravaggio: A Life Sacred and Profane (London: Allen Lane, 2010). 
Graziani, Françoise, "Limites du monde. Limites de la pensée”, in La limite. XVI ${ }^{e s}$ entretiens de La Garenne Lemot, éd. Jackie Pigeaud (Rennes: Presses Universitaires de Rennes, 2012), p. 23 (21-32).

Grieco, Sara F. Matthews, Ange ou diablesse. La répresentation de la femme au $X V I^{e}$ siècle (Paris: Flammarion, 1991).

Greenblatt, Stephen, "Remnants of the Sacred in Early Modern England", in Subject and Object in Renaissance Culture, ed. Margareta De Grazia, Maureen Quilligan, and Peter Stallybrass (Cambridge: Cambridge University Press, 1996), pp. 337-45.

- Hamlet in Purgatory (Princeton: Princeton University Press, 2001).

Greene, R.A., "Synderesis, the Spark of Conscience, in the English Renaissance", Journal of the History of Ideas, 52(1991): 195-219.

Greenwood, John, Shifting Perspectives and the Stylish Style: Mannerism in Shakespeare and His Jacobean Contemporaries (Toronto, Buffalo, and London: University of Toronto Press, 1988).

Gregori, Mina, "Preliminari a una rilettura del Caravaggio", in Caravaggio (Milan: Electa, 1993), pp. 9-26.

—, "Riflessioni sulle origini della natura morta. Da Leonardo a Caravaggio", in La natura morta al tempo di Caravaggio (Naples: Electa, 1995), pp. $15-25$.

- "Caravaggio, La Tour, Zurbaran, Rembrandt: ombra e luce", in La luce del vero: Caravaggio, La Tour, Zurbaran, Rembrandt: ombra e luce (Cinisello Balsamo: Silvana Editoriale, 2000), pp. 18-39.

- "Come dipingeva Caravaggio" ("The Way Caravaggio Painted"), in Come lavorava Caravaggio (Rome: Viviani Editore- Romartificio, 2006), pp. 15-22.

- "Caravaggio's first 'Medusa' - La prima 'Medusa' del Caravaggio", in The First Medusa - La prima Medusa - Caravaggio, ed. Ermanno Zoffili (Milan, 5 Continents Edition, 2011), pp. 12-27.

Groves, Beatrice, "Comedic Form and Paschal Motif in the First and Second Quartos of Romeo and Juliet", in Texts and Traditions. Religion in Shakespeare 1592-1604 (Oxford: Clarendon Press, 2007), 60-88.

Guest, Claire Lapraik, "On Energeia", in Imitation, Representation and Priting in the Italian Renaissance, ed. Roy Eriksen and Magne Malmanger (Pisa, Rome: Fabrizio Serra Editore, 2009), pp. 83-100.

Gunzburg, Darrelyn, “Giotto's Sky: The Fresco Paintings of the First Floor Salone of the Palazzo della Ragione, Padua, Italy”, Journal for the Study of Religion, Nature and Culture, 7, 4(2013): 407-33.

Hall, Marcia B., Color and Meaning: Practice and Theory in Renaissance Painting (Cambridge: Cambridge University Press, 1992).

- "Caravaggio: Secularizing the Sacred, Sanctifying the Secular", in The Sacred Image in the Age of Art: Titian, Tintoretto, Barocci, El Greco, Caravaggio (New Haven and London: Yale University Press, 2011), pp. 249-67.

Hamlin, Hannibal, "Damnable Iteration: Falstaff, Master of Biblical Allusion", in The Bible in Shakespeare (Oxford: Oxford University Press, 2013), 231-70.

Harries, Karsten, Infinity and Perspective (Cambridge, MA: The MIT Press, 2001). 


\section{Bibliography}

Harris, Jonathan Gil, “Narcissus in thy Face': Roman Desire and the Difference It Fakes in Antony and Cleopatra", Shakespeare Quarterly, 45, 4(1994): 408-25.

Hass, Angela, “Caravaggio's 'Calling of St Matthew' Reconsidered”, Journal of the Warburg and Courtauld Institutes, 51(1988): 245-50.

Hazard, Mary E., "The Anatomy of 'Liveliness' as a Concept in Renaissance Aesthetics", The Journal of Aesthetics and Art Criticism, 33, 4(1975): 407-18.

-, “An Essay to Amplify 'Ornament': Some Renaissance Theory and Practice”, Studies in English Literature, 1500-1900, 16(1976): 15-32.

- Elizabethan Silent Language (Lincoln and London: University of Nebraska Press, 2000).

Healy, Margaret, Shakespeare, Alchemy and the Creative Imagination (Cambridge: Cambridge University Press, 2007).

Heffernan, James A.W., "The Painted Rape of Troy in Shakespeare's Lucrece", in Museum of Words: The Poetics of Ekphrasis from Homer to Ashbery (Chicago and London: The University of Chicago Press, 1993), pp. 74-90.

Heffernan, Julián Jiménez, Shakespeare’s Extremes: Wild Man, Monster, Beast (Houndmills: Palgrave Macmillan, 2015).

Hendrix, John S., "Perception as a Function of Desire in the Renaissance", in Renaissance Theories of Vision, ed. John S. Hendrix and Charles H. Carman (Aldershot: Ashgate, 2010), 89-102.

Hibbard, Howard, Caravaggio (New York: Harper \& Row, 1983).

Hill, Paul, The Light of Early Italian Painting (New Haven and London: Yale University Press, 1987).

Hillman, David, "Visceral Knowledge", in The Body in Parts: Fantasies of Corporeality in Early Modern Europe, ed. D. Hillman and C. Mazzio (London and New York: Routledge, 1997), pp. 81-106.

Hoff, L. Kay, Hamlet's Choice: Hamlet - A Reformation Allegory (Lewiston, Queenston, and Lampeter: The Edwin Mellen Press, 1990).

Hohnen, D., Hamlet's Castle and Shakespeare's Elsinore (Copenhagen: Christian Ejlers, 2000).

Holderness, Graham, The Faith of William Shakespeare (Oxford: Lion, 2016).

Hommes, Margriet van Eikema, and van de Wetering, Ernst, "Light and Colour in Caravaggio and Rembrandt, As Seen Through the Eyes of Their Contemporaries", in Rembrandt/Caravaggio, ed. Duncan Bull (Zwolle: Waanders, 2006), pp. 164-79.

Howard, Deborah, "Elsheimer's Flight into Egypt and the Night Sky in the Renaissance”, Zeitschrifte für Kunstgeschichte, 55 Bd. H. 2(1992): 212-24.

Howard, Maurice, "The Treatise and Its Alternatives: Theory and Pratice in Sixteenth-Century England", in Théorie des arts et création artistique dans l'Europe du Nord du XVIe au début du XVIIIe siècle, ed. Michèle-Caroline Heck, Frédérique Lemerle et Yves Pauwels (Lille: Collection UL3 Travaux et recherches, 2002), pp. 141-53.

Hulse, Clark, “'A Piece of Skilful Painting' in Shakespeare's Lucrece”, Shakespeare Survey, 32(1978): 13-22.

_- "Shakespeare's Sonnets and the Art of the Face", in Essays in Literature and the Visual Arts, ed. Richard S. Peterson, John Donne Journal, 5, 1-2(1986): 3-26.

Hunt, J., "A Thing of Nothing: the Catastrophic Body in Hamlet", Shakespeare Quarterly 39(1988): 27-44.

Hunt, Patrick, Caravaggio (London: Haus Publishing, 2004). 
, "Irony and Realism in the Iconography of Caravaggio's Penitent Magdalene", in Mary Magdalene, Iconographic Studies from the Middle Ages to the Baroque, ed. Michelle A. Erhardt and Amy M. Morris (Leiden and Boston: Brill, 2012), pp. 161-86.

Hurt, Joseph, "Les arts rivaux", Neophilologus, 72(1988): 168-79.

Husserl, Edmund, Ideas Pertaining to a Pure Phenomenology and to a Phenomenological Philosophy, first book, transl. F. Kersten (Dordrecht: Kluwer Academic Publishers, 1982).

Hutson, Lorna, "Law, Probability and Character in Shakespeare", in Fictions of Knowledge. Fact, Evidence, Doubt, ed. Y. Batsaki, S. Mukherji, and J.-M. Schramm (New York: Palgrave Macmillan, 2012), pp. 61-83.

Jacobs, Frederika H., The Living Image in Renaissance Art (Cambridge: Cambridge University Press, 2005).

Jay, M., "Scopic Regimes of Modernity", in Vision \& Visuality, ed. H. Foster (Seattle: Bay Press, 1988), pp. 3-23.

Jori, Giacomo, Per evidenza. Conoscenza e segni nell'età barocca (Venice: Marsilio, 1998).

Joughin, John J., "Shakespeare, Modernity and the Aesthetic: Art, Truth and Judgement in The Winter's Tale", in Shakespeare and Modernity: Early Modern to Millennium, ed. Hugh Grady (London and New York: Routledge, 2000), pp. 61-84.

Kahn, Coppélia, Roman Shakespeare. Warriors, Wounds, and Women (London and New York: Routledge, 1997).

Kalas, Rayna, Frame, Glass, Verse. The Technology of Poetic Invention in the English Renaissance (Ithaca and London: Cornell University Press, 2007).

Kapstein, Matthew T., "Rethinking Religious Experience: Seeing the Light in the History of Religions", in The Presence of Light: Divine Radiance and Religious Experience, ed. Matthew T. Kapstein (London and Chicago: University of Chicago Press, 2004), pp. 265-99.

Kamerick, Kathleen, "Staying the Senses: Image and Word in Prayer Books", in Popular Piety and Art in the Late Middle Ages. Image Worship and Idolatry in England 1300-1500 (New York: Palgrave, 2002), pp. 155-90.

Katz, Jerrold, "The Refutation of Indeterminacy", The Journal of Philosophy, 85, 5(1988): 227-52.

Knapp, James A., "Visual and Ethic Truth in The Winter's Tale", Shakespeare Quarterly, 55(2004): 253-78.

- Image Ethics in Shakespeare and Spenser (New York: Palgrave Macmillan, 2011).

Knoespel, Kenneth J., Narcissus and the Invention of Personal History (New York and London: Garland Publishing, 1985).

Knowles, James, "Insubstantial Pageants: The Tempest and Masquing Culture", in Shakespeare's Late Plays. New Readings, ed. Jennifer Richards and James Knowles (Edinburgh: Edinburgh University Press, 1999), pp. 108-25.

Knowles, Ronald, "Hamlet and Counter-Humanism”, Renaissance Quarterly, 52, 4(1999): 1046-99.

Koslofsky, Craig, Evening's Empire: A History of the Night in Early Modern Europe (Cambridge: Cambridge University Press, 2011).

Kretzmann, Norman, "Goodness, Knowledge, and Indeterminacy in the Philosophy of Thomas Aquinas", The Journal of Philosophy, 80, 10 (1983), Part 2: 631-49. 
Krieger, Murray, Ekphrasis: The Illusion of the Natural Sign (Baltimore and London: The Johns Hopkins University Press, 1992).

Kristeva, Julia, “Approaching Abjection”, in Powers of Horror (New York: Columbia University Press, 1982), pp. 1-31.

Krüger, Klaus, "Authenticity and Fiction: On the Pictorial Construction of Inner Presence in Early Modern Italy", in Image and Imagination of the Religious Self in Late Medieval and Early Modern Europe, ed. R. Falkenburg, W.S. Melion, and T.M. Richardson (Turnhout: Brepols, 2007), pp. 37-69.

Kuchar, Gary, Divine Subjection: The Rhetoric of Sacramental Devotion in Early Modern England (Pittsburgh: Duquesne University Press, 2005).

Lacan, Jacques, "Desire and the Interpretation of Desire in Hamlet", Yale French Studies, 55/56(1977): 11-52.

Lake, Peter, "Julius Caesar and the Search for a Usable (Christian?) Past", in Shakespeare and Early Modern Religion, ed. David Loewenstein and Michael Witmore (Cambridge: Cambridge University Press, 2015), pp. 111-30.

Lambotte, Marie-Claude, "La destinée en miroir", in Les vanités dans la peinture au XVII siècle. Méditations sur la richesse, le dénuement et la rédemption, ed. Alain Tapié (Caen: Musée des Beaux-Arts, 1990), pp. 31-41.

Laneyrie-Dagen, Nadeije, L'invention de la nature. Les quatre éléments à la Renaissance ou le peintre premier savant (Paris: Flammarion, 2008).

Langdon, Helen, Caravaggio: A Life (London: Chatto \& Windus, 1998).

Langley, Eric, Narcissism and Suicide in Shakespeare and His Contemporaries (Oxford: Oxford University Press, 2009).

Lapucci, Roberta, Caravaggio e l'ottica - Caravaggio and Optics (Florence: Rest \& Art, 2005).

Larim Cooper, Farah, The Hand on the Shakespearean Stage: Gesture, Touch and the Spectacle of Dismemberment (London: Bloomsbury, 2016).

Laroque, François, "Macbeth: Theatre of Image to Shadow Theatre", in Spectacle \& Image in Renaissance Europe: Selected Papers of the XXXII ${ }^{\text {nd }}$ Conference of the Centre d'Etudes Supérieures de la Renaissance de Tours 29 June-8 July 1989 (Leiden: Brill, 1993), pp. 147-76.

—, "Rare Italian Master(s): Roman Art in Romeo and Juliet, Antony and Cleopatra, and The Winter's Tale", in Shakespeare, Italy, and Intertextuality, ed. M. Marrapodi (Manchester: Manchester University Press, 2004), pp. 227-38.

Latour, Bruno, We Have Never Been Modern, transl. Chaterine Porter (Cambridge: Harvard University Press, 1993).

Lavin, Irving, "Divine Inspiration in Caravaggio's Two St. Matthews”, The Art Bulletin, 56(1974): 59-81.

LeCoat, Gerard, The Rhetoric of the Arts, 1550-1650 (Bern: Herbert Lang, Frankfurt/M.: Peter Lang, 1975).

Lee, Rensselaer W., Ut Pictura Poesis: The Humanistic Theory of Painting (New York and London: W.W. Norton \& Company, 1967).

Lefebvre, Philippe, o.p., "Lumière dans la nuit. La Bible comme art photographique", in Le symbolisme de la lumière au Moyen-Âge: de la spéculation à la réalité (Chartres, AACMEC, 2004), pp. 7-28.

Lemoine, Annick, "Questioni di iconografia caravaggesca. La scena in genere, tra 'ludicrum' moralizzato e riflessione metafisica”, in Caravaggio $e$ 
l'Europa: l'artista, la storia, la tecnica e la sua eredità (Cinisello Balsamo: Silvana Editoriale, 2009), pp. 187-96.

Lerner, Michel-Pierre, Le monde des spheres, I. Genèse et triomphe d'une représentation cosmique (Paris: Les Belles Lettres, 1996).

- II. La fin du cosmos classique (Paris: Les Belles Lettres, 1997).

Leslie, Michael, "The dialogue Between Bodies and Souls: Picture and Poesy in the English Renaissance”, Word \& Image, 1, 1(1985): 16-30.

Lestringant, Frank, Une sainte horreur ou le voyage en Eucharistie: $X V I^{e}-X V I I I^{e}$ siècle (Paris: Presses universitaires de France, 1996).

- "Utopia and the Reformation", transl. Nadia Benadid, in Utopia: The Search for the Ideal Society in the Western World, ed. Roland Schaer, Gregory Claes, and Lyman Tower Sargent (New York: Oxford University Press, 2000), pp. 161-77.

Levy, David H., The Starlight Night: The Sky in the Writings of Shakespeare, Tennyson, and Hopkins (London: Springer, 2016), pp. 13-23.

Lewalski, Barbara Kiefer, "Typological Symbolism and the 'Progress of the Soul' in Seventeenth-Century Literature", in Literary Uses of Typology from the Late Middle Ages to the Present (Princeton: Princeton University Press, 1977), pp. 79-114.

Lewis, Marthin W., "Dividing the Ocean Sea", Geographical Review, 89, 2(1999): 188-214.

Lewith, Murray J., "Coriolanus and the Flaying of Marsyas", in Shakespeare and the Visual Arts, ed. Holger Klein and James L. Harner (Lewiston, Queenston, and Lampeter: The Mellen Press, 2000), pp. 442-53.

Lexicon Iconographicum Mythologiae Classicae (Zurich and München: Artemis Verlag, 1981-99).

Lievsay, John L., The Englishman's Italian Books: 1550-1700 (Philadelphia: University of Pennsylvania Press, 1969).

Lindberg, David C., “The Genesis of Kepler's Theory of Light: Light Metaphysics from Plotinus to Kepler", Osiris, 2(1986): 4-42.

Linden, Stanton J., “Mystical Alchemy, Eschatology, and Seventeenth-Century Poetry", Pacific Coast Philology, 19, 1/2(1984): 79-88.

Linton, Joan Pong, "The Passing of Falstaff: Rethinking History, Refiguring the Sacred", in Shakespeare and Religion. Early Modern and Postmodern Perspectives, ed. Ken Jackson and Artrhur F. Marotti (Notre Dame: University of Notre Dame, 2011), pp. 205-27.

Llewellyn, Nigel, The Art of Death: Visual Culture in the English Death Ritual c. 1500-c. 1800 (London: Reaktion Books, 1992).

Lobis, Seth, The Virtue of Sympathy: Magic, Philosophy, and Literature in Seventeenth-century England (New Haven and London: Yale University Press, 2015).

Lobsien, Verena Olejniczak, "Squaring the Circle: Neoplatonic Versions of the Self in Early Modern Poetry", in Literature and Circularity, ed. C. Henke and M. Middeke, Symbolism: An International Annual of Critical Aesthetics, 9(2009): 13-39.

- Transparency and Dissimulation: Configurations of Neoplatonism in Early Modern English Literature (Berlin: De Gruyter, 2010).

Loewenstein, David, "Agnostic Shakespeare?: The Godless World of King Lear", in Shakespeare and Early Modern Religion, ed. David Loewenstein 


\section{Bibliography}

and Michael Witmore (Cambridge: Cambridge University Press, 2015), $155-71$.

Loire, Stéphane, and Arnauld Brejon de Lavergnée, Caravage: La mort de la Vierge. Une Madonne sans dignité (Paris: Adam Biro, 1990).

Longhi, Roberto, Caravaggio (Rome: Editori Riuniti, 1977).

Lupton, Julia Reinhard, and Kenneth Reinhard, After Oedipus. Shakespeare in Psychoanalysis (Ithaca and London: Cornell University Press, 1993).

Lyne, Raphael, Ovid's Changing Worlds. English Metamorphoses, 1567-1632 (Oxford: Oxford University Press, 2001).

MacCulloch, Diarmaid, Silence: A Christian History (New York: Viking, 2013).

MacFaul, Tom, Shakespeare and the Natural World (Cambridge: Cambridge University Press, 2015).

Macioce, Stefania (ed.), Michelangelo Merisi da Caravaggio. La vita e le opere attraverso i documenti. Atti del Convegno Internazionale di Studi, ed. Stefania Macioce (Rome: Logart Press, 1996).

- Michelangelo Merisi da Caravaggio: Fonti e documenti 1532-1724 (Rome: Ugo Bozzi Editore, 2003).

- "Ut pictura rhetorica. Affetti, devozione e retorica nei dipinti di Caravaggio", Storia dell'arte, 116/117 (2007): 67-100.

Mahon, Denis (ed.), Caravaggio. L'immagine del Divino (Rome: Romartificio, 2007).

Maus, Katharine Eisaman, Being and Having in Shakespeare (Oxford: Oxford University Press, 2013).

McFarland, Thomas, "Field, Constellation, and Aesthetic Object", New Literary History, 13, 3(1982): 412-47.

McGinn, Bernard, "Visio Dei. Seeing God in Medieval Theology and Mysticism", in Envisaging Heaven in the Middle Ages, ed. C. Muessig and A. Putter (London and New York: Routledge, 2007), pp. 15-33.

Mack, Peter, "Early Modern Ideas of Imagination. The Rhetorical Tradition", in Imagination in the Later Middle Ages and Early Modern Times, ed. L. Nauta and D. Pätzold (Leuven, Paris, and Dudley, MA: Peeters, 2004), pp. 59-76.

Maisano, Scott, "New Directions: Shakespeare's Revolution - The Tempest as Scientific Romance", in The Tempest. A Critical Reader, ed. Alden T. Vaughan and Virginia Mason Vaughan (London: Bloomsbury, 2014), pp. 165-94.

Mansfield, Elizabeth C., "Myth and Mimesis in the Renaissance", in Too Beautiful to Picture: Zeuxis, Myth, and Mimesis (Minneapolis and London: University of Minnesota Press, 2007), pp. 39-53.

Maquerlot, Jean-Pierre, Shakespeare and the Mannerist Tradition: A Reading of Five Problem Plays (Cambridge: Cambridge University Press, 1995).

Marchitello, Howard, "Shakespeare's Othello and Vesalius's Fabrica: Anatomy, Gender, and the Narrative Production of Meaning", in Narrative and Meaning in Early Modern England (Cambridge: Cambridge University Press, 1997), pp. 10-38.

Margolin, Jean-Claude, "Le silence à la Renaissance dans la tradition hermétiste et pythagoricienne et dans la pratique de l'intersubjectivité", in Le silence à la Renaissance, éd. Marie-Thérèse Jones-Davies (Turnhout: Brepols, 2015), 17-33. Marini, Maurizio, Io Michelangelo da Caravaggio (Rome: Studio "B” Bestetti e Bozzi Editori, 1974). 
(with Federico Zeri) Caravaggio e il naturalismo internazionale, in Storia dell'arte italiana, VI: Dal Cinquecento all'Ottocento, I: Cinquecento e Seicento (Turin: Einaudi, 1981), pp. 347-445.

_- "'Inventarium omnium et singulorum bonorum mobilium' di Michelangelo da Caravaggio Pittore”, Artibus et historiae, 28(1993): 161-76.

— Caravaggio: Michelangelo Merisi da Caravaggio "pictor praestantissimus" (Rome: Newton Compton, 2001).

—. "Maddalena in estasi. Scheda filologica", in Michelangelo da Caravaggio: La Maddalena di Paliano, ed. Maurizio Marini (Rome: De Luca Editori d'Arte, 2006), pp. 25-34.

Marrapodi, Michele (ed.), Shakespeare and the Visual Arts. The Italian Influence (Abingdon and New York: Routledge, 2017).

Marshall, Cynthia, The Shattering of the Self. Violence, Subjectivity, and Early Modern Texts (Baltimore and London: The Johns Hopkins University Press, 2002).

Marshall, Peter, Beliefs and the Dead in Reformation England (Oxford: Oxford University Press, 2002).

Martin, John Jeffries, Myths of Renaissance Individualism (Houndmills: Palgrave Macmillan, 2004).

Martindale, Charles and Martindale Michelle, Shakespeare and the Uses of Antiquity. An Introductory Essay (London and New York: Routledge, 1994 [1990]).

Massa, D., "Giordano Bruno's Ideas in Seventeenth-Century England”, Journal of the History of Ideas, 38, 2(1977): 227-42.

Mazza, Enrico, L'action eucharistique: origine, développement, interprétation, transl. Jacques Mignon (Paris: Editions du Cerf, 1999).

Melchior-Bonnet, Sabine, "Miroirs et identité à la Renaissance", in Miroirs: jeux et reflets depuis l'Antiquité (Paris: Somogy éditions d'art, 2000), pp. 135-48.

Melion, Walter S., "Introduction: Meditative Images and the Psychology of Soul", in Image and Imagination of the Religious Self in Late Medieval and Early Modern Europe, ed. Reindert Falkenburg, Walter S. Melion, and Todd M. Richardson (Turnhout: Brepols, 2007), pp. 1-36.

- "Meditative Images and the Portrayal of Image-Based Meditation", in Ut Pictura Meditatio. The Meditative Image in Northern Art, 1500-1700, ed. W.S. Melion, R. Dekoninck, and Agnes Guiderdoni-Bruslé (Turnhout: Brepols, 2012), pp. 1-60.

Ménager, Daniel, La Renaissance et la nuit (Genève: Droz, 2005).

Mendoza, Ramon G., The Acentric Labyrinth: Giordano Bruno's Prelude to Contemporary Cosmology (Shaftesbury: Element, 1995).

Mentz, Steve, At the Bottom of Shakespeare's Ocean (London and New York: Continuum, 2009).

Merriman, James D., "The Parallel of the Arts: Some Misgivings and a Faint Affirmation", Journal of Aesthetics and Art Criticism, 31 (1972-1973): pp. 153-64, 309-21.

Michalski, Sergiusz, The Reformation and the Visual Arts: The Protestant Image Question in Western and Eastern Europe (London and New York: Routledge, 1993).

Millikan, Ruth Garren, "On Clear and Indistinct Ideas", Philosophical Perspectives, 8(1994): 75-100. 


\section{Bibliography}

Mitchell, W.J.T., Iconology. Image, Text, Ideology (Chicago and London: The University of Chicago Press, 1986).

- Picture Theory. Essay on Verbal and Visual Representation (Chicago: The University of Chicago Press, 1994).

Moffitt, John F., Caravaggio in Context: Learned Naturalism and Renaissance Humanism (Jefferson, NC and London: McFarland \& Company, 2004).

Molnar, M.R., "The Magi's Star from the Perspective of Ancient Astrological Practices", Quarterly Journal of the Royal Astronomical Society, 36(1995): 109-26.

Monta, Susannah Brietz, Martyrdom and Literature in Early Modern England (Cambridge: Cambridge University Press, 2005).

Monteyne, Joseph, The Printed Image in Early Modern London: Urban Space, Visual Representation, and Social Exchange (Aldershot: Ashgate, 2007).

Montgomery, Scott L., The Moon and the Western Imagination (Tucson: The University of Arizona Press, 1999).

Moshenka, John, Feeling Pleasure: The Sense of Touch in Renaissance England (Oxford: Oxford University Press, 2014).

Mosley, Adam, "Past Portents Predict: Cometary Historiae and Catalogues", in Celestial Novelties on the Eve of the Scientific Revolution: 1540-1630, ed. Dario Tessicini and Patrick J. Boner (Florence: Olschki, 2013), pp. 1-32.

Moss, Daniel D., The Ovidian Vogue: Literary Fashion and Imitative Practice in Late Elizabethan England (Toronto: University of Toronto Press, 2014).

Moxey, Keith, Visual Time. The Image in History (Durham and London: Duke University Press, 2013).

Mullaney, Stephen, "Imaginary Conquests: European Material Technologies and Colonial Mirror Stage", in Early Modern Visual Culture: Representation, Race, and Empire in Renaissance England, ed. P. Erickson and C. Hulse (Philadelphia: University of Pennsylvania Press, 2009), pp. 15-43.

Nagel, Alexander, The Controversy of Renaissance Art (Chicago and London: University of Chicago Press, 2011).

Nagel, Alexander, and Lorenzo Piccolo, "Unresolved Images: An Introduction to Aporia as an Analytical Category in the Interpretation of Early Modern Art", in Subject as Aporia in Early Modern Art, ed. Alexander Nagel and Lorenzo Pericolo (Farnham: Ashgate, 2010), pp. 1-15.

Narcy, M., et Sfez, G. (éd.), Dispositifs du sujet à la Renaissance (Paris: PUF, 2000).

Nesselrath, Heinz-Günther, "Where the Lord of the Sea Grants Passage to Sailors through the Deep-Blue Mere No More': The Greeks and the Western Seas", Greece \& Rome, 52, 2(2005): 153-71.

Nordlund, Marcus, The Dark Lantern: A Historical Study of Sight in Shakespeare, Webster, and Middleton (Goteborg: Acta Universitatis Gothoburgensis, 1999).

North, John, "Macrocosm, Microcosm, and Analogy", in Imagination in the Later Middle Ages and Early Modern Times, ed. L. Nauta and D. Pätzold (Leuven, Paris, and Dudley, MA: Peeters, 2004), pp. 135-51.

Nuttall, A.D., "Ovid's Narcissus and Shakespeare's Richard II: The Reflected Self", in Ovid Renewed: Ovidian Influences on Literature and Art from the Middle Ages to the Twentieth Century, ed. Charles Martindale (Cambridge: Cambridge University Press, 1988), pp. 137-50. 
The Object as Subject. Studies in the Interpretation of Still Life, ed. Anne W. Lowenthal (Princeton: Princeton University Press, 1996).

Olson, Greta, "Richard III's Animalistic Criminal Body”, Philological Quarterly, 82, 3(Summer 2002): 301-24.

Olson, Todd P., "Pitiful Relics: Caravaggio's Martyrdom of St. Matthew", Representations, 77,1 (2002): 107-42.

Olszewski, Edward T., "Distortions, Shadows, and Conventions in Sixteenth Century Italian Art”, Artibus et Historiae, 6, 11(1985): 101-24.

Orgel, Stephen, and Sean Keilen (ed.), Shakespeare and the Arts (New York and London: Garland Publishing, 1999).

- "Idols of the Gallery: Becoming a Connoisseur in Renaissance England", in Early Modern Visual Culture: Representation, Race, and Empire in Renaissance England, ed. Peter Erickson and Clark Hulse (Philadelphia: University of Pennsylvania Press, 2000), pp. 251-83.

Owens, Margaret E., Stages of Dismemberment: The Fragmented Body in Late Medieval and Early Modern Drama (Newark: University of Delaware Press, 2005).

Pacifici, Paola, "Chairs mortifiées. Connaissance anatomique et esthétique de la souffrance dans la répresentation des martyrs au XVI ${ }^{\mathrm{e}}$ et au XVII siècle", in Corps sanglants, souffrants et macabres XVI ${ }^{e}-X V I I^{e}$ siècle, éd. Charlotte Bouteille-Meister et Kjerstin Aukrust (Paris: Presses Sorbonne Nouvelle, 2010), pp. 18-30.

Panofsky, Erwin, Problems in Titian: Mostly Iconographic (New York: New York University Press, 1969).

Panzera, Anna Maria, Caravaggio, Giordano Bruno e l'invisibile natura delle cose (Rome: L'asino d'oro edizioni, 2011).

Parks, N. Randolph, “On Caravaggio's 'Dormition of the Virgin' and Its Setting”, The Burlington Magazine, 127, 988(1985): 438-48.

Parronchi, Alessandro, "La 'camera ombrosa' del Caravaggio", in La luce del vero: Caravaggio, La Tour, Zurbaran, Rembrandt: ombra e luce (Cinisello Balsamo: SilvanaEditoriale, 2000), pp. 66-79.

Parshall, Peter, "Imago Contrafacta: Images and Facts in the Northern Renaissance", Art History, 16, 4(1993): 554-79.

Pastoreau, Michel, Black: The History of a Color, transl. Jody Gladding (Princeton and Oxford: Princeton University Press, 2009).

- Symboles du Moyen Age. Animaux, végétaux, couleurs, objets (Paris: Le Léopard d'Or, 2012).

Peacock, John, "The Politics of Portraiture", in Culture and Politics in Early Stuart England (London: Macmillan, 1994), pp. 199-228.

Pendergast, John S., "Pierre de Moulin on the Eucharist: Protestant Sign Theory and the Grammar of Embodiment", English Literary History, 65, 1(1998): 47-68.

Pericolo, Lorenzo, Caravaggio and Pictorial Narrative: Dislocating the 'Istoria' in Early Modern Painting (London: Harvey Miller Publishing, 2011).

Phillips, John, The Reformation of Images: Destruction of Art in England, 1535-1660 (Berkeley, Los Angeles, and London: University of California Press, 1973).

Pichler, Wolfram, "Il dubbio e il doppio: le evidenze in Caravaggio", in Caravaggio e il suo ambiente. Ricerche e interpretazioni, ed. Sybille Ebert-Schifferer, 


\section{Bibliography}

Julian Kliemann, Valeska von Rosen, and Lothar Sickel (Cinisello Balsamo: SilvanaEditoriale, 2007), pp. 9-33.

Pinkus, Karen, Picturing Silence: Emblem, Language, Counter-reformation Materiality (Ann Arbor: University of Michigan Press, 1996).

Plett, Heinrich F., in Enargeia in Classical Antiquity and the Early Modern Age: The Aesthetics of Evidence (Boston and Leiden: Brill, 2012).

Pomel, Fabienne, "Présentation: reflexions sur le miroir", in Miroirs et jeux de miroirs dans la literature médiéval, éd. F. Pomel (Rennes: Presses Universitaires de Rennes, 2003), pp. 17-26.

Poole, Kristen, Supernatural Environments in Shakespeare's England: Spaces of Demonism, Divinity, and Drama (Cambridge: Cambridge University Press, 2011).

Popper, Nicholas, “'Abraham, Planter of Mathematics': Histories of Mathematics and Astrology in Early Modern Europe", Journal of the History of Ideas, 67, 1(2006): 87-106.

Poulet, Georges, La pensée indéterminée. I, De la Renaissance au romantisme (Paris: Presses Universitaires de France, 1985).

Preimesberger, Rudolf, "Pittura Gobba: Conjectures on Caravaggio's Entombment", in Paragons and Paragone: Van Eyck Raphael Michelangelo Caravaggio Bernini, transl. Fiona Elliott (Los Angeles: The Getty Research Institute, 2011), pp. 83-107.

Puglisi, Catherine, Caravaggio (London: Phaidon Press, 1998).

Puttfarken, Thomas, "Caravaggio's 'Story of St. Matthew': A Challenge to the Conventions of Painting”, Art History, 21, 2(1998): 163-81.

Pye, Christopher, The Vanishing: Shakespeare, the Subject, and Early Modern Culture (Durham and London: Duke University Press, 2000).

Quinlan-McGrath, Mary, Influences. Art, Optics, and Astrology in the Italian Renaissance (Chicago and London: The University of Chicago Press, 2013).

Quiring, Björn, Shakespeare's Curse: The Aporias of Ritual Exclusion in Early Modern Royal Drama (London and New York: Routledge, 2014).

Raber, Karen, "The Tusked Hog: Richard III's Boarish Identity”, in Animals and Early Modern Identity, ed. Pia F. Cuneo (Aldershot: Ashgate, 2014), pp. 191-207.

Rabouin, David, Mathesis universalis. L'idée de 'mathématique universelle' d'Aristote à Descartes (Paris: Presses Universitaires de France, 2009).

Reading the Early Modern Dream: The Terrors of the Night, ed. Katharine Hodgkin, Michelle O'Callaghan, and S.J. Wiseman (New York and London: Routledge, 2008).

Reeves, Eileen, Painting the Heavens: Art and Science in the Age of Galileo (Princeton: Princeton University Press, 1997).

- "Kingdoms of Heaven: Galileo and Sarpi on the Celestial”, Representations, 105, 1(2009): 61-84.

Riehl, A., The Face of Queenship: Early Modern Representations of Elizabeth I (New York: Palgrave Macmillan, 2010).

Risse, Matthias, “Arrow's Theorem, Indeterminacy, and Multiplicity Reconsidered", Ethics, 111, 4(2001): 706-734.

Roos, Anna Marie E., Luminaries in the Natural World. The Sun and the Moon in England, 1400-1720 (New York: Peter Lang, 2001).

Rosenthal, Olivia, Donner à voir: écritures de l'image dans l'art de poésie au $X V I^{e}$ siècle (Paris: Honoré Champion Éditeur, 1998). 
Rossi, Sergio, "Peccato e redenzione negli autoritratti del Caravaggio", in $\mathrm{Mi}$ chelangelo Merisi da Caravaggio. La vita e le opere attraverso i documenti, ed. Stefania Macioce (Rome: Logart Press, 1996), pp. 316-27.

Russell, Bertrand, "Vagueness" (1923), in Vagueness. A Reader, ed. Rosanna Keffe and Peter Smith (Cambridge, MA and London: The MIT Press, 1996), pp. 61-8.

Rzepińska, Maria (transl. Krystina Malcharek), “Tenebrism in Baroque Painting and Its Ideological Background", Artibus et Historiae, 7, 13(1986): 91-112.

Saarinen, Risto, Weakness of Will in Renaissance and Reformation Thought (Oxford: Oxford University Press, 2011).

Sabatier, Armelle, Shakespeare and Visual Culture. A Dictionary (London: Bloomsbury, 2016).

Saffrey, H.D., "L'homme-microcosme dans une estampe medico-philosophique du seizième siècle", Journal of the Warburg and Courtauld Institutes, 57(1994): 89-122.

Saint Girons, Baldine, "La peinture et la nuit", in Du visible à l'intelligible: lumières et ténèbres de l'Antiquité à la Renaissance, ed. Christian Trottmann and Anca Vasiliu (Paris: Honoré Champion, 2004), pp. 281-305.

Salkeld, Duncan, "Silence, Seeing, and Performativity: Shakespeare and the Paragone", in Shakespeare and Renaissance Literary Theories: Anglo-Italian Transactions, ed. Michele Marrapodi (Aldershot: Ashgate, 2011), pp. 247-64.

Sanger, Alice E., and Siv Tove Kulbrandstad Wlaker (ed.), Sense and the Senses in Early Modern Art and Cultural Practice (Farnham: Ashgate, 2012).

Sangha, Laura, Angels and Belief in England, 1480-1700 (London: Pickering \& Chatto, 2012).

Sapir, Itay, Ténèbres sans leçons. Esthétiques et épistémologie de la peinture ténébriste romaine 1595-1610 (Bern: Peter Lang, 2012).

Sapori, Giovanna, "Stampe da Caravaggio e caravaggeschi”, in Caravaggio e l'Europa: l'artista, la storia, la tecnica e la sua eredità (Cinisello Balsamo: SilvanaEditoriale, 2009), pp. 157-68.

Saxo Grammaticus and the Life of Hamlet: A Translation, History, and Commentary, ed. W.F. Hansen (Lincoln and London: University of Nebraska Press, 1983).

Sawday, Jonathan, The Body Emblazoned. Dissection and Human Body in Renaissance Culture (London: Routledge, 1995).

- "Self and Selfhood in the Seventeenth Century", in Rewriting the Self. Histories from the Renaissance to the Present, ed. Roy Porter (London and New York: Routledge, 1997), pp. 29-48.

Scalabroni, Luisa, Vanitas: fisionomia di un tema pittorico (Alessandria: Edizioni dell'Orso, 1999).

Schmutz, Jacob, “L'existence de l'Ego comme premier principe métaphysique avant Descartes", in Généalogies du sujet: de saint Anselme à Malebranche, éd. par Olivier Boulnois (Paris: Vrin, 2007), pp. 215-68.

Schoenfeldt, Michael C., "Embodiment and Interiority in Early Modern England", in Bodies and Selves in Early Modern England: Physiology and Inwardness in Spenser, Shakespeare, Herbert, and Milton (Cambridge: Cambridge University Press, 1999), pp. 1-39.

Schultz, Bernard, Art and Anatomy in Renaissance Italy (Ann Arbor: UMI Research Press, 1985). 


\section{Bibliography}

Schwarz, Kathryn, "Death and Theory: Or, the Problem of Counterfactual Sex", in Sex Before Sex: Figuring the Act in Early Modern England, ed. James M. Bromley and Will Stockton (Minneapolis and London: University of Minnesota Press, 2013), pp. 53-88.

Scott, Charlotte, Shakespeare and the Idea of the Book (Oxford: Oxford University Press, 2007).

- Shakespeare's Nature. From Cultivation to Culture (Oxford: Oxford University Press, 2014).

Scribner, Charles III, “In Alia Effigie: Caravaggio's London Supper at Emmaus", The Art Bulletin, 59, 3(1977): 375-82.

Searle, John, "Indeterminacy, Empiricism, and the First Person", The Journal of Philosophy, 84, 3(1987): 123-46.

Serracino-Inglott, Peter, "Ars Moriendi-Ad Usum Proprium: Aspects of Dealing with Death in Caravaggio", in Caravaggio and Paintings of Realism in Malta, ed. Cynthia De Giorgio and Keith Sciberras (Malta: Midsea Books, 2007), pp. 89-100.

Shannon, Laurie, The Accommodated Animal. Cosmopolity in Shakespearean Locales (Chicago and London: University of Chicago Press, 2013).

Shell, Alison, Catholicism, Controversy and the English Literary Imagination, 1558-1660 (Cambridge: Cambridge University Press, 1999).

Sherwood, Terry G., The Self in Early Modern Literature: For the Common Good (Pittsburgh: Duquesne University Press, 2007).

Shuger, Debora, Habits of Thought in the English Renaissance: Religion, Politics, and the Dominant Culture (Toronto: University of Toronto Press, 1997).

_ "The 'I' of the Beholder: Renaissance Mirrors and the Reflective Mind", in Renaissance Culture and the Everyday, ed. P. Fumerton and S. Hunt (Philadelphia: University of Pennsylvania Press, 1999), pp. 21-41.

Siebers, Tobin, The Mirror of Medusa (Berkeley, Los Angeles, and London: The University of California Press, 1983).

Simons, Patricia, "Portraiture, Portrayal, and Idealization: Ambiguous Individualism in Representations of Renaissance Women”, in Language and Images of Renaissance Italy, ed. Alison Brown (Oxford: Clarendon Press, 1995), pp. 263-312.

Skow, Bradford, "Deep Metaphysical Indeterminacy”, The Philosophical Quarterly, 60, 241(2010): 851-58.

Slights, William W.E., The Heart in the Age of Shakespeare (Cambridge: Cambridge University Press, 2008).

Sloan, Kim, 'A Noble Art': Amateur Artists and Drawing Masters c. 1600-1800 (London: British Museum Press, 2000).

Sluhovsky, Moshe, "Loyola's Spiritual Exercises and the Modern Self", in A Companion to Ignatius of Loyola: Life, Writings, Spirituality, Influence, ed. Robert Aleksander Maryks (Leiden and Boston: Brill, 2014).

Smith, A. Mark, From Sight to Light: The Passage from Ancient to Modern Optics (Chicago: University of Chicago Press, 2015).

Smith, Jane Kingley, “Aristotelian Shame and Christian Mortification in Love's Labour's Lost", in Shakespeare and Renaissance Ethics, ed. Patrick Gray and John D. Cox (Cambridge: Cambridge University Press, 2014), 76-97.

Soellner, Ralph, Shakespeare's Patterns of Self-Knowledge (Columbus: Ohio State University Press, 1972). 
Sohmer, S., "Certain Speculations on Hamlet, the Calendar, and Martin Luther”, Early Modern Literary Studies, 2, 1.5(1996): 1-51.

Sokol, B.J., Art and Illusion in 'The Winter's Tale' (Manchester and New York: Manchester University Press, 1994).

Spear, Richard E., “The 'Raising of Lazarus': Caravaggio and the Sixteenth Century Tradition”, Gazette des Beaux-Arts, 65(1965): 65-70.

Spencer, John R., "Ut Rhetorica Pictura: A Study in Quattrocento Theory of Painting", The Journal of the Warburg and Courtauld Institutes, 20, 1-2(1957): 26-44.

Spencer, T.J.B., "The Imperfect Parallel Between Painting and Poetry”, Greece \& Rome, Second Series, VII, 2(1960): 173-86.

Spica, Anne-Élisabeth, "Rhétorique et herméneutique du discours sacré dans la literature en images de l'âge baroque: quelques pistes de recherché”, in Emblemata Sacra. Rhétorique et herméneutique du discours sacré dans la literature en images, éd. R. Denkoninck et A. Guiderdoni-Bruslé (Turnhout: Brepols, 2007), pp. 19-38.

Spike, John T., Caravaggio (New York and London: Abbeville Press Publishers, 2001).

Spiller, Elizabeth, Science, Reading, and Renaissance Literature: The Art of Making Knowledge, 1580-1670 (Cambridge: Cambridge University Press, 2004).

Spinrad, Phoebe S., The Summons of Death on the Medieval and Renaissance English Stage (Columbus: Ohio State University Press, 1987).

Stainton, Lindsay, and White, Christopher, Drawing in England from Hilliard to Hogarth (London: British Museum Publications, 1987).

Stark, Caroline, "Reflections of Narcissus", in The Afterlife of Ovid, ed. P. Mack and J. North (London: Institute of Classical Studies, 2015), pp. 23-41.

Steadman, John M., Nature into Myth: Medieval and Renaissance Moral Symbols (Pittsburgh: Duquesne University Press, 1979).

Stegman, André, "Richness and Ambivalence of the Symbol in the Renaissance", in Image and symbol in the Renaissance, Yale French Studies, 47(1972): 5-18.

Stelling, Lieke, “Thy Very Essence is Mutability': Religious Conversion in Early Modern English Drama, 1558-1642", in The Turn of the Soul: Representations of Religious Conversion in Early Modern Art and Literature (Leiden and Boston: Brill, 2012), pp. 59-83.

Stockhausen, Carol Kern, Moses' Veil and the Glory of the New Covenant: The Exegetical Substructure of II Cor. 3, 1-4, 6 (Rome: Editrice Pontificio Istituto Biblico, 1968), pp. 87-122.

Stoichita, Victor, L'instauratio du tableau: métapeinture à l'aube des temps modernes (Paris: Méridiens Klincksieck, 1993).

- A Short History of the Shadow, transl. Anne-Marie Glasheen (London: Reaktion Books, 1997).

Stoll, Abraham, “Macbeth's Equivocal Conscience”, in Macbeth. New Critical Essays, ed. Nick Moschovakis (New York and London: Routledge, 2008), pp. 132-50.

Stone, David M., "In Figura Diaboli: Self and Myth in Caravaggio's David and Goliath", in From Rome to Eternity: Catholicism and the Arts in Italy, ca. 1550-1650, ed. P.M. Jones and T. Worcester (Leiden, Boston, and Köln: Brill, 2002), pp. 19-42. 
Stone, M.W.F., "Conscience in Renaissance Moral Thought: A Concept in Transition?”, Renaissance Studies, 23, 4(2009): 423-44.

Stowell, Steven, "Artistic Devotion: Imitations of Art and Nature in Italian Renaissance Writings on Art", in Inganno - The Art of Deception: Imitation, Reception, and Deceit in Early Modern Art, ed. Sharon Gregory and Sally Anne Hickson (Aldershot: Ashgate, 2012), pp. 21-46.

Strinati, Claudio Massimo, L'immagine di San Francesco nella Controriforma (Rome: Edizioni Quasar, 1982).

$\longrightarrow$, and R. Voudret (ed.), Caravaggio. La luce nella pittura lombarda (Milan: Electa, 2000).

- "Pietas': le stigmata di Caravaggio", in Caravaggio: l'immagine del divino, ed. Denis Mahon (Rome: Romartificio, 2007), pp. 142-55.

String, Tatiana C., Art and Communication in the Reign of Henry VIII (Aldershot: Ashgate, 2008).

Strong, Roy, The English Icon: Elizabethan \& Jacobean Portraiture (London: Routledge; Kegan Paul and New York: Pantheon Books, 1969).

- The English Renaissance Miniature (London: Thames and Hudson, 1983).

- The Tudor and Stuart Monarchy: Pageantry, Painting, Iconography, 3 vols (Woodbridge: The Boydell Press, 1995).

Stumpel, Jeroen, "Speaking of Manner: Maniera and its Meanings", in The Province of Painting: Theories of Italian Renaissance Art (Utrecht: private ed., 1990), pp. 97-128.

Suber, P., "Infinite Reflections", St. John's Review, 44(1998): 1-59.

Sullivan, Ceri, Dismembered Rhetoric: English Recusant Writing, 1580 to 1603 (Madison and Teaneck: Fairleigh Dickinson University Press; London: Associated University Presses, 1995).

Sullivan, Erin, "A Disease unto Death: Sadness in the Time of Shakespeare", Emotions and Health, 1200-1700, ed. Elena Carrera (Leiden and Boston: Brill, 2013), pp. 159-84.

Sullivan, Garrett A., Memory and Forgetting in English Renaissance Drama: Shakespeare, Marlowe, Webster (Cambridge: Cambridge University Press, 2007).

Summers, David, The Judgment of Sense: Renaissance Naturalism and the Rise of Aesthetics (Cambridge: Cambridge University Press, 1987).

- Vision, Reflection, and Desire in Western Painting (Chapel Hill: University of North Carolina Press, 2007).

Taylor, Charles, Sources of the Self: The Making of Modern Identity (Cambridge: Cambridge University Press, 1989 [1994]).

Taylor, Paul, Condition: the Ageing of Art (London: Paul Holberton Publishing, 2015).

Thatcher, D., “Sullied Flesh, Sullied Mind: Refiguring Hamlet's Imaginations”, Studia Neophilologica, 68(1996): 29-38.

Thorne, Alison, Vision and Rhetoric in Shakespeare. Looking through Language (Houndmills: Macmillan, 2000).

Tittler, Robert, "Portraiture and Memory Amongst the Middling Elites in Post-Reformation England", in The Arts of Remembrance in Early Modern England. Memorial Cultures of the Post Reformation (Farnham: Ashgate, 2013), pp. 37-57. 
Treffers, Bert, "I piedi dell'affetto", in Arte francescana e pauperismo della valle dell'Aniene: l'exempum di Subiaco, ed. G. Crescentini (Subiaco: Edizioni Iter, 1997), pp. 123-28.

- Caravaggio nel sangue del Battista (Rome: Edizioni dell'Associazione Culturale Shakespeare and Company, 2000).

Troubetzkoy, V., L'ombre et la différence: le double en Europe (Paris: PUF, 1996).

Turrell, James F., "Anglican Theologies of the Eucharist”, in A Companion to the Eucharist in the Reformation, ed. Lee Palmer Wandel (Leiden: Brill, 2014), pp. 139-58.

Van Dijkhuizen, Jan Frans, "Partakers of Pain: Religious Meanings of Pain in Early Modern England", in The Sense of Suffering. Constructions of Physical Pain in Early Modern Culture, ed. J.F. van Dijkhuizen and K.A.E. Enenkel (Leiden and Boston: Brill, 2009), pp. 189-220.

Van Eck, Caroline, Classical Rhetoric and the Visual Arts in Early Modern Europe (Cambridge: Cambridge University Press, 2007).

Varriano, John, "Caravaggio and Religion", in Saints and Sinners: Caravaggio and the Baroque Image, ed. Franco Mormando (Chestnut Hill, MA: Charles S. And Isabella V. McMullen Museum of Art, 1999), pp. 191-207.

- Caravaggio: The Art of Realism (University Park: The Pennsylvania State University Press, 2006).

Vedrenne, Isabelle, "L'homme sous la mer: la figure du plongeur dans le monde gréco-romain et l'Occident médiéval", in Dans l'eau, sous l'eau: le monde aquatique au Moyen Age, éd. Danièle James-Raoul et Claude Thomasset (Paris: Presses de l'Université de Paris-Sorbonne, 2002), pp. 273-319.

Vendler, Helen, The Art of Shakespeare's Sonnets (Cambridge, MA: Harvard University Press, 1997).

Verbraeken, René, Clair-Obscur, -histoire d'un mot (Nogent-le-Roi: Jacques Laget, 1979).

Vernant, Jean-Pierre, "Death in the Eyes: Gorgo, Figure of the Other", in Mortals and Immortals: Collected Essays, ed. F.I. Zeitlin (Princeton: Princeton University Press, 1991), pp. 111-38.

Viladesau, Richard, "The Protestant Reformation in the Church and the Arts", in The Triumph of the Cross. The Passion of Christ in Theology and the Arts, from the Renaissance to the Counter-Reformation (Oxford: Oxford University Press, 2008), pp. 103-81.

Vodret, Rossella, "Caravaggio: The Mystery of the Two 'Saint Francis in Meditation'”, in Caravaggio. The Mystery of the Two 'Saint Francis in Meditation, ed. Rossella Vodret (Cinisello Balsamo: SilvanaEditoriale, 2009), pp. 21-57.

Von Lates, Adrianne, "Caravaggio's Peaches and Academic Puns”, Word and Image, 11, 1(1995): 55-60.

Waage, Frederick O., “'Be Stone No More’: Italian Cinquecento Art and Shakespeare's Last Plays”, Bucknell Review, 25, 1(1980): 56-87.

Wajeman, Lise, "Profanation de la nudité sacrée", in Nudité sacrée. Le nu dans l'art religieux de la Renaissance entre érotisme, devotion et censure, éd. Elisa de Halleux et Marianna Lora (Paris: Publications de la Sorbonne, 2011), pp. 19-32.

Waldron, Jennifer, Reformations of the Body. Idolatry, Sacrifice, and Early Modern Theater (New York: Palgrave Macmillan, 2013). 


\section{Bibliography}

Walker, Suzanne J., "Making and Breaking the Stag. The Construction of the Animal in the Early Modern Hunting Treatise", in Early Modern Zoology. The Construction of Animals in Science, Literature and the Visual Arts, ed. Karl A.E. Enenkel and Paul J. Smith (Leiden and Boston: Brill, 2007), pp. 317-37.

Walsham, Alexandra, "Angels and Idols in England's Long Reformation", in Angels in the Early Modern World, ed. P. Marshall and A. Walsham (Cambridge: Cambridge University Press, 2006), pp. 134-67.

- "Skeletons in the Cupboard: Relics after the English Reformation", in Relics and Remains, ed. A. Walsham (Oxford: Oxford University Press, 2010), pp. 121-43.

- "Idols in the Frontispiece? Illustrating Religious Books in the Age of Iconoclasm", in Illustrated Religious Texts in the North of Europe, 1500-1800, ed. F. Dietz et al. (Farnham: Ashgate, 2014), pp. 21-52.

Wandel, Lee Palmer, "The Reformed Eucharist", in The Eucharist in the Reformation (Cambridge: Cambridge University Press, 2006), pp. 139-207.

- "John Calvin and Michel de Montaigne on the Eye", in Early Modern Eyes, ed. Walter S. Melion and Lee Palmer Wandel (Leiden and Boston: Brill, 2010), pp. 135-55.

Warma, Susanne J., "Christ, First Fruits, and the Resurrection: Observations on the Fruit Basket in Caravaggio's London Supper at Emmaus", Zeitschrift für Kunstgeschichte, 53, 4(1990): 583-86.

Watson, Robert N., The Rest Is Silence: Death as Annibilation in the English Renaissance (Berkeley, Los Angeles, and London: University of California Press, 1994).

Webb, Ruth, "Ekphrasis Ancient and Modern: The Invention of a Genre”, Word \& Image, 15, 1(1999): 7-18.

Weinberg, Florence M., The Cave: The Evolution of a Metaphoric Field from Homer to Ariosto (New York: P. Lang, 1986).

Weisstein, Ulrich, "Influences and Parallels: The Place and Function of Analogy Studies in Comparative Literature", in Teilnahme und Spiegelung. Festschrift für Horst Rüdiger (Berlin and New York: Walter de Gruyter, 1975), pp. 593-609.

-, "The Venial Sins of the Intermedialist or How to Avoid the Mutual Obfuscation of the Arts", in Metamorphosing Shakespeare: Mutual Illuminations of the Arts, ed. Patricia Kennan and Mariangela Tempera (Bologna: Clueb, 2004), pp. 11-29.

Wells-Cole, Anthony, Art and Decoration in Elizabethan and Jacobean England: The Influence of Continental Prints, 1558-1625 (New Haven and London: Yale University Press, 1997).

Weststeijn, Thijs, "Seeing and the Transfer of Spirits in Early Modern Art Theory", in Renaissance Theories of Vision, ed. John S. Hendrix and Charles H. Carman (Aldershot: Ashgate, 2010), pp. 149-69.

White, Roger M., Talking about God: The Concept of Analogy and the Problem of Religious Language (Aldershot: Ashgate, 2010).

Whitfield, Clovis, Caravaggio's Eye (London: Paul Holberton Publishing, 2011). Wilks, John S., The Idea of Conscience in Renaissance Tragedy (London and New York: Routledge, 1990). 
Wooding, Lucy, "Remembrance in the Eucharist", in The Arts of Remembrance in Early Modern England. Memorial Cultures of the Post Reformation (Farnham: Ashgate, 2013), pp. 19-36.

Wright, I., "'Come Like Shadowes, So Depart': The Ghostly Kings in Macbeth", Shakespearean International Yearbook, 6(2006): 215-29.

Wright, M.R., Cosmology in Antiquity (London and New York: Routledge, 1995).

Wunderli, R. and Broce, G., “The Final Moment before Death in Early Modern England”, The Sixteenth Century Journal, 20(1989): 259-75.

Zandri, Giuliana, "Un probabile dipinto murale del Caravaggio per il Cardinale Del Monte", Storia dell'arte, 3(1969): 338-43.

Zellini, Paolo, Breve storia dell'infinito (Milan: Adelphi, 2001).

Ziegler, Georgianna, "Picturing Venus and Adonis: Shakespeare and the Artists", in Venus and Adonis: Critical Essays, ed. Philip C. Kolin (New York and London: Garland Publishing, 1997), pp. 389-403.

Zilberfain, Ava, Stealing the Story: Shakespeare's Self-Conscious Use of the Mimetic Tradition in the Tragedies (New York and London: Continuum, 2007).

Zimmerman, Susan, The Early Modern Corpse and Shakespeare's Theatre (Edinburgh: Edinburgh University Press, 2005).

Zöllner, Frank, "The 'Motions of the Mind' in Renaissance Portraits: The Spiritual Dimension of Portraiture", Zeitschrift für Kunstgeschichte, 68, 1(2005): 23-40.

Zuccari, Alessandro, Caravaggio controluce. Ideali e capolavori (Genève and Milan: Skira, 2011).

_ , “Mors et vita duello conflixere mirando'. La Resurrezione di Lazzaro del Caravaggio", in Caravaggio: la resurrezione di Lazzaro, ed. Daila Radeglia (Rome: Palombi, 2012), pp. 21-7. 
This page intentionally left blank 